\title{
Political Institutions and Policy Choices: Evidence from the United States*
}

\author{
Timothy Besley \\ London School of Economics \\ London WC2A 2AE \\ U.K.
}

\author{
Anne Case \\ Princeton University \\ Princeton NJ 08544 \\ U.S.A.
}

July 2002

\begin{abstract}
A rich array of institutional diversity makes the United States an excellent place to study the relationship between political institutions and public policy outcomes. This essay has three main aims. First, it reviews existing empirical evidence on the relationship between institutional rules, political representation and policy outcomes. It aims to place the literature into a broader context of theoretical and empirical work in the field of political economy. Second, it develops a parallel empirical analysis that updates studies in the literature and re-examines some of the claims made, in a setting unified both in terms of policy outcomes and the period under study. Third, the paper develops some new directions for research, presenting a small number of novel exploratory results.
\end{abstract}

\footnotetext{
${ }^{*}$ We are grateful to Jim Alt, Mark Crain, three referees and John McMillan for helpful comments and advice. Erlend Berg, Silvia Pezzini, Susanna Peralta and James Vere provided helpful research assistance.
} 


\section{Introduction}

In recent years, there has been increased interest in bringing economics and politics together to understand policy. This resurgence of political economy has generated new questions and new models. Insights from game theory, contract theory, and mechanism design theory now permeate our understanding of the political sphere. ${ }^{1}$ The recent literature has paid much more attention to theory than empirics. This essay highlights the progress that has been made in empirical political economy using variations in institutional rules across the United States.

The essence of the literature is illustrated in the following example. A number of states have recently passed laws that tie voter registration to motor vehicle registration, so-called "motor-voter" laws. The intention is to promote voting, particularly among disadvantaged groups that have low rates of turnout. Here, we might ask three questions. First, does the passage of such laws lead to greater turnout? Second, does this change in turnout (if there is one) change the composition of the legislature, for example, by increasing representation of Democrats? Third, does the increase in Democrat representation (if there is one) have an influence on policy outcomes? In principle, these questions can be addressed empirically using available data, and we discuss the answers below. In thinking through these possible chains of influence (as documented in the data), one is also drawn to thinking about the right theoretical context in which to understand the policy process.

The paper studies a rather heterogeneous group of institutions. Thus, the term institution should be understood in the rather broad sense suggested by Douglass North (1990) as "the humanly devised constraints that structure human interaction" (page 3). We use the term institutional choice in preference to the narrower idea of a constitutional rule, which suggests a formally encoded mandate. As observed by a number of commentators (such as Avinash Dixit (1996)) it does not make an awful lot of sense to draw hard distinctions between terms like institution, constitutional rule and (even) policies. Moreover, in practice, those who study constitutional economics use an equally broad conception of the term constitution. For example, Geoffrey Brennan and Alan Hamlin (1998) characterize constitutional economics as studying the "basic rules under which social orders may operate"

\footnotetext{
${ }^{1}$ Torsten Persson and Guido Tabellini (2000) bring many of these together in an excellent survey of the field.
} 
(page 401).

The survey will restrict itself to evidence based on cross-state institutional differences in the United States. This has costs and benefits. The main cost lies in the limited range of institutional differences that can be considered across US states. While there are some interesting and important differences available, there are a host of common features whose implications cannot be studied in this way. The United States cannot, for example, be used to test the difference between proportional and first-pass-the-post electoral systems. However, the broadly common institutional and constitutional setting is also a benefit. There is real hope of isolating the true source of differences, rather than attributing to a particular institution some effect that is, in reality, due to unobserved heterogeneity. This contrasts with much work using crosscountry data. A further benefit from the US focus is the availability of a wide range of existing studies on all aspects of institutional differences.

In addition to reviewing the main contributions in the area, we also present new empirical results. By using a consistent set of data and methods, this will provide an additional perspective on the issues in question. It will also help us to illustrate some of the methodological issues involved in making use of cross-state institutional variation to study policy outcomes.

Most of the work that is discussed below is by economists. However, there is also a large body of relevant work coming out of political science departments. Within political science, there is far from universal acceptance of the value of formal and quantitative reasoning. The debate surrounding Donald Green and Ian Shapiro (1994) is indicative of this. Green and Shapiro criticize the willingness of formally inclined political scientists to engage in empirical testing. This essay is partly an effort to promote the work that has been done. However, it is clear from the existing literature that the evolution of theory and empirical evidence on understanding political institutions has been unbalanced. Much of the empirical testing eschews interpretation of results in terms of models, and hence fails to push forward the debates about modeling. At the other end, a good deal of theory seems to be lifting insights from game theory, contract theory and information economics without pushing testable implications.

The remainder of the paper is organized as follows. The next section presents some background discussion of the literature and the evolution of thinking in the field of political economy. Section 3 develops a framework for the study of political competition and discusses its empirical implications for the study of how political institutions affect policy outcomes. Section 
4 reviews how institutional arrangements vary across US states. Section 5 studies institutions that directly affect the process of political representation, to see whether and how they affect voter turnout and such legislative outcomes as political ideology and the party composition of the legislature and governor. Section 6 then examines how political representation affects state policies, particularly those of taxing and spending. Section 7 considers institutional effects on policy outcomes, either through direct influence or through their proximate effect on representation. These middle sections of our paper follow the plan set out in Figure 1.

[FIGURE 1 HERE]

Section 8 turns to the question of how institutional rules are made and changed. Section 9 concludes.

\section{Background}

Understanding how institutions change policy is an important intellectual end in itself. However, it is also part of the kit bag that economists need to improve the way in which the world works. Among the pioneers of the vision that a just polity involves the design of appropriate rules for policy formation is James Buchanan. ${ }^{2}$ A great deal of public economics is about the choice of policies - the level of taxation, whether to mandate health insurance, etc. However, there are two reasons to think that this should be augmented with studies that go back one stage prior and evaluate the process on the basis of which policy is made. First, institutional reforms are frequently on the agenda and we need to have a framework (and empirical knowledge) for judging them. Second, the policy advice and insights that economists offer are mediated through the political system. It may be that once the workings of the political system are understood, then we would change the policy advice that we give. Policies that appeared sub-optimal may be desirable because of the way in which they are operated in political equilibrium. But this raises the larger question of whether it is better to change the rules by which policies are formed than to advocate policy changes themselves. This, then, requires an understanding of the mapping from institutional rules to policy outcomes.

\footnotetext{
${ }^{2}$ See, for example, Buchanan (1967) and (1987).
} 
One rather grand view of policy making, suggested by Buchanan, is to think of there being two stages of analysis. At the first stage, a constitution is designed. ${ }^{3}$ This has two components. A procedural constitution sets the terms by which decisions are made (electoral rules, term limits, the separation of powers etc.). A fiscal constitution builds in constraints on the policies that can be adopted within the framework of the procedural constitution. This might, for example, include limits on taxation or particular forms of public spending. After the constitution is determined, policies are chosen. However, these are autonomous, and the key role for the policy advisor is at stage one, anticipating the outcome at stage two from some underlying model. ${ }^{4}$

While useful as a benchmark, the distinction between a rule and policy is quite narrow (see, for example, the discussion in Dixit (1996)). A good example is the rule that prohibited many US states from levying an income tax, but which has been overturned by most states during the twentieth century. This kind of fiscal rule then looks much closer to what we would ordinarily call a policy than a rule. In practice, there may be larger costs associated with changing some aspects of the policy framework than others - the need for ratification by two thirds majorities is a good example. Thus, it is probably a little dangerous to try to draw a hard-and-fast distinction between the immutable constitution and the pliable policy arena.

The notion of designing an optimal constitution is tinged with hubris. In practice, the optimizing approach to policy analysis can be solved only under very stylized assumptions about the economic environment and incentive problems. Moreover, the bewildering array of different policy issues needing to be solved makes the notion of specifying the optimal constitution a distant dream. On a more practical level, we might hope to understand the workings of particular institutional changes. Much as in policy economics, we can debate how particular interventions - such as minimum wages or publicly funded broadcasting - affect the economy. The contributions surveyed here are more in pursuit of this agenda and make progress for precisely this reason. While it is true that there are probably important interactions between policy decisions - for example increasing the minimum wage may result in adjustments to welfare policy - we need to begin where concrete progress can

\footnotetext{
${ }^{3}$ See Jean-Jacques Laffont (2000) for a conception of the optimal constitution problem from a mechanism design perspective.

${ }^{4}$ Timothy Besley and Stephen Coate (2001) develop a very simple model that illustrates the issues that might arise in the design of a fiscal constitution.
} 
be made.

Most of the institutional changes analyzed here are procedural, in Buchanan's terminology, although there will be exceptions (balanced budget restrictions being a key example). Institutional rules are of two broad kinds: (i) electoral rules: restrictions on who can vote, whether proportional representation is used etc., and (ii) decision making rules: the use of line item vetoes, whether certain agencies are independent. The distinction is, however, not a very precise one.

To understand the effect of an institutional change on policy outcomes requires an underlying model of the policy process. The importance of providing theoretical foundations is two-fold. First, the interpretation of a particular effect is normally (consciously or unconsciously) tied to a model. Second, and more importantly, is a concern about the potential generalizability of the findings. If the sole aim of a study is to answer a narrowly-posed question (did a particular historical institutional change have some impact?), then this may not be necessary. However, most authors would like to claim a result of more wide-ranging significance. This can most often be achieved by showing that it illuminates some particular theoretically validated relationship. The studies that are discussed below vary greatly in the extent to which the author(s) spell out the theory behind their results.

The political economy literature has developed a plethora of models that can be employed to address a wide range of questions, and here is not the place to develop any kind of survey of them. However, we will make a few comments about the theoretical literature that will be germane to what follows. For a comprehensive tour of the field see Persson and Tabellini (2000).

A great deal of theoretical political economy literature begins from the notion that policies should line up with the preferences of the median voter. Indeed, for a long period this was almost a caricature of economists' forages into political economy. The motivation comes from two key contributions - (i) the observation (most often attributed to Duncan Black (1987)) that restrictions on preferences (most often single-peakedness) imply that the median voter's preferred point is a Condorcet winner, ${ }^{5}$ and (ii) the observation due to Anthony Downs (1957) that two parties who care only about winning would pick out the Condorcet winner if they could commit to policies during

\footnotetext{
${ }^{5} \mathrm{~A}$ Condorcet winner is a policy that would beat all others in binary comparisons based on majority rule.
} 
an election campaign. In spite of the model's centrality in the literature, both components provide a deeply flawed basis for thinking through the implications of political competition for policy determination. First, policy environments with multiple issues rarely have a Condorcet winner. Second, the assumptions about commitment and motivation in the Downsian paradigm are unreasonable and outcomes are highly unrobust to deviations from them. If parties care about policy, this may have significant implications for the credibility of their ex ante policy pronouncements. For example, Alberto Alesina (1988) shows that whether complete convergence of parties' policies is possible, even in an infinitely repeated game, will depend on such parameters as the parties' discount rates, polarization of preferences, and the relative popularity of the parties.

Progress in theoretical political economy has had to wait for modeling approaches that leave the straightjacket imposed by the Downsian paradigm behind them. Political economy thrived in some quarters by throwing out explicit electoral modeling completely as, for example, in Sam Peltzman (1976) and Gary Becker (1985). However their reduced-form approaches do not provide a way for thinking about the policy implications of institutional changes. It has also become apparent that, if we are to have a realistic hope of generating predictions that might apply in reality, then modeling needs an approach that allows the simultaneous functioning of elections and interest groups . Progress on this front has been slow but Gene Grossman and Elhanan Helpman (1996) and Persson and Tabellini (2000, section 7.5) point the way ahead.

Literatures have also sprung up that de-emphasize the spatial choice component of elections, instead concentrating on the role of elections in curbing opportunistic behavior of politicians (see, for example, Robert Barro (1973) and John Ferejohn (1986)). Below, we will argue that some of the cross-state literature from the United States speaks to the relevance of this approach for explaining the data.

Among political scientists, a large literature developed that focused on approaches to solving the problems of multi-issue decision making at the level of legislatures, but rarely has this been mapped back to overall electoral consequences. However, a key insight emerges from this that is useful in many other contexts. Part of the difficulty in the Downsian paradigm is the fact that there is little institutional restriction on policy proposals. It is very difficult to get a stable point when any policy can be proposed by any political actor at any time. Kenneth Shepsle and Barry Weingast (1981) discuss how 
restrictions of the structure of proposal power within a legislature can be used to generate a stable point in a multi-dimensional policy space.

Restricting proposal power can be valuable in other contexts. It is at the heart of the celebrated model of agenda setting due to Thomas Romer and Howard Rosenthal (1978). For example, Besley and Coate (1997) restrict policies to those that are optimal for some citizen. John Roemer (1999) restricts proposal power by modeling within-party conflict. Such restrictions improve the odds of developing a model that predicts an equilibrium outcome in a particular policy context, providing a basis for empirical analysis.

The notion that the structure of the power to propose policy is important is really part of a more generally valuable insight, that the structure of political institutions affects political outcomes. This is the core idea behind the empirical literature we discuss below. It should also be clear that this is likely to rest on departures from the median voter logic that has dominated so much of the political economy literature. If policies we see in the world really are responsive to the median voter's preferred point in any kind of general sense, then there is no good reason to think that the institutional structure of decision making would matter much at all.

One particular theoretical issue that is highlighted by many empirical studies is the need for a tractable framework to study the allocation of multiple issues. Most often analysts are interested in studying the impact of institutional rules that may affect only some part of the policy space or, at least, would affect different parts in varying ways. Thus, consider the effect of increased voter registration among minority voters. We would typically want to consider the impact of this on general policies and those that particularly affect the groups in question. However, to think about this requires a model where the impacts on both group-specific and general policies are considered. It would not, for example, make much sense to consider a world where redistribution towards minorities (in the form, say, of affirmative action) were the only policy being determined in political equilibrium. Political scientists are well aware that changes in the salience of issues is central to understanding the evolution of policy (see, for example, Edward Carmines (1994)). However, economists do not have well-developed frameworks for handling this. ${ }^{6} \quad$ Some play has been obtained from the multi-dimensional models of Assar Lindbeck and Jorgen Weibull (1993) and Dixit and John

\footnotetext{
${ }^{6}$ Besley and Coate $(2000 \mathrm{a}, \mathrm{b})$ also provide a way of thinking about salience in a multiple issue framework and how institutions can change the salience of issues.
} 
Londregan (1998). They envisage two ideologically opposed parties who court groups of voters by promising transfers. While this yields useful insights, it cannot address the question of when the ideological dimension may shift - as arguably has been the case in a number of time periods in the U.S. It also seems odd to invoke such strong assumptions about commitment to transfers without specifying the mechanism by which credibility is achieved.

The post-Downsian literature in political economy suggests the following simple three-way theoretical classification of the importance of institutions on policy formation. First, institutions may affect policy preferences directly, and their expression at the ballot box. The simplest possibility is their effect on who votes. However, policy preferences may change for a given voting population. For example, a voter may be more willing to tolerate a Democrat bound by a tax and expenditure limitation. Second, in a multi-issue world, institutions can affect policy priorities. Thus, incentives to target transfer programs to particular groups may change if that group is registered to vote. As argued in Besley and Coate (2000b), allowing voters to place legislation directly on the ballot via citizens' initiatives can unbundle a particular policy issue and change its salience to voters. Third, institutions can change the ability of the policy process and particular politicians to commit. For example, a term-limit may reduce the credibility of election promises since an incumbent may not run again for office. These three effects can go a good way towards interpreting many of the findings below.

\section{An Organizing Framework}

This section serves two main purposes. We present a model of the different components of the policy process, which will serve as a unifying framework in the subsequent discussion of the literature. In addition, we discuss the kinds of empirical tests that follow naturally from the framework.

\subsection{Components of the Policy Process}

The policy process constitutes an embarrassment of riches for applied research. We begin laying out the components of that process that might be studied empirically. While in practice most researchers take a reduced-form approach, looking at the components helps to lay bare the assumptions that implicitly go into the interpretation of the effects of institutions on outcomes. 
For the purposes of our theoretical discussion, we partition the institutions that vary across the US states into two vectors denoted by $I_{1 s t}$ and $I_{2 s t}$, with $I_{s t}$ denoting the full institutional vector. The vector $I_{1 s t}$ contains those institutions that are typically thought to affect the policy process for a given structure of political representation. For the purposes of this essay, they are:

- Policy Making Institutions $\left(I_{1 s t}\right)$. Restrictions on the governor's and legislators' freedoms, including tax and expenditure limitations; super-majority requirements for tax increases; the governor's possession of a line item veto; rules for appointing regulators and judges; rules governing whether a state permits direct democracy, such as citizens' initiatives; and rules on whether governors face term limits.

The vector $I_{2 s t}$ comprises that set of institutions that affect the way in which elections are conducted. In this essay, these are:

- Electoral Institutions $\left(I_{2 s t}\right)$. Rules affecting who can run for office and who can vote, including those affecting the costs of registering to vote (such as poll taxes and literacy tests); those regulating campaign contributions in state elections; and those governing the conduct of primary elections.

Both lists contain rules on whether a state permits direct democracy, such as citizens' initiatives, and rules on whether a governor faces a term limit. From a theoretical point of view, a case could be made for them having an influence at both of the stages that we discuss below. More generally, the distinction between policy making and electoral institutions need not be hard and fast. We use it primarily as a device for organizing the literature. In principle, any of the institutions we analyze could belong to both $I_{1 s t}$ and $I_{2 s t}$.

\subsubsection{Preferences}

Virtually all approaches to political processes take the preferences of voters and partes as given, and we shall do so here. Suppose then that preferences of voters are defined over a policy space $x_{s t} \in \mathcal{A}_{t}$. This is a potentially wide-ranging description of all policies that can be controlled or influenced by state governments in the U.S.. Suppose also that heterogeneity across the voting population can be parametrized for voter $i$ by $\theta_{i} \in \Theta$. In practical terms, the vector $\theta_{i}$ would include the ideological stance of each voter and 
their views on other key issues such as gun control or abortion. Preferences can be written as:

$$
v\left(x_{s t}, y_{s t}, \theta_{i}\right)
$$

where $y_{s t}$ is a vector of state demographic and economic characteristics that affect policy preferences. ${ }^{7}$ Let $\Theta_{s t}$ parametrize the distribution of voter tastes in the population in state $s$ at date $t$. There is plenty of evidence of substantial heterogeneity in distributions of preferences across the states see, for example, Gerald Wright, Robert Erikson, and John McIver (1987) .

Also relevant are party preferences of the Democratic and Republican party in each state. We denote these by:

$$
V\left(x_{s t}, \chi_{j s t}, y_{s t}\right) \text { for } j \in\{D, R\}
$$

where $\chi_{j s t}$ parametrizes the distribution of party members and/or influential party elites. ${ }^{8}$ It is widely documented that $\chi_{D s t}$ and $\chi_{R s t}$ are distinct. However, there may also be substantial differences between states. Received wisdom among political scientists also suggests that elites are important in politics and can hold views that are distinct from average opinion among voters. This suggests that $\chi_{j s t}$ differs from $\Theta_{s t}$.

Data exist to characterize some elements of party and voter preferences. Here, we use the cross-state series created by William Berry, Evan Ringquist, Richard Fording and Russell Hanson (1998). However, there is potentially a richer set of data available through polling surveys. Such data form the basis of the work of Wright, Erikson and McIver (1987) and Erikson, Wright and McIver (1989).

\footnotetext{
${ }^{7}$ These are reduced form preferences based on a model of how policy affects outcomes that voters care about.

${ }^{8}$ These preferences could be derived from voter preferences by supposing that that a subset of voters belong to the parties. If $\mathcal{M}_{j}$ denote the set of members of party $j$. Then

$$
V\left(x, \chi_{j s t}, y_{s t}\right)=\sum_{\theta_{j} \in \Theta, j \in \mathcal{M}_{j}} v\left(x, y_{s t}, \theta\right) \pi\left(\theta ; \chi_{j s t}\right) ; j \in\{D, R\}
$$
}

where $\pi\left(\theta ; \chi_{j s t}\right)$ is the density of taste characteristics in party $j$ in state $s$ at time $t$. 


\subsubsection{The Post-Election Policy Process}

To describe the post-election policy process, let $\ell_{s t}$ be a variable that characterizes the political outcomes in state $s$ at time $t$. This, for example, would include the composition of the legislature and any relevant information about the governor. Our legislative outcome function is:

$$
x_{s t}=G\left(\ell_{s t}, X_{D s t}, X_{R s t}, I_{1 s t}, y_{s t}\right)
$$

where $X_{j s t}$ be the "platform" of party $j$ in state $s$ at time $t,{ }^{9}$ and $I_{1 s t}$ are the policy making institutional variables discussed above including, for example, whether the governor has a line item veto or whether there is a supermajority required for tax increases. The function $G(\cdot)$ is intended to capture, in reduced-form, a potentially complicated policy process such as a legislative bargaining model or a model of the separation of powers between the executive and the legislature.

In principle, the mapping from institutions into policy outcomes induced by (1) can be studied empirically. To do this, consider the following empirical model for the $k t h$ policy in state $s$ at time $t$ of the form:

$$
x_{k s t}=\alpha_{k s}+\beta_{k t}+\omega_{k} I_{1 s t}+\gamma^{k} y_{s t}+\psi^{k} \ell_{s t}+d_{k} X_{D s t}+r_{k} X_{R s t}+\eta_{k s t},
$$

where $\alpha_{k s}$ is a state indicator variable and $\beta_{k t}$ is a year indicator. The focus is on how $I_{1 s t}$ affects the outcome of interest. For ordinary least squares to yield an unbiased estimate of $\omega_{k}$, it is clear that all relevant elements of $\ell_{s t}$ need to be included, as they are likely to be correlated with $I_{1 s t}$ and that $\left(X_{D s t}, X_{R s t}\right)$ must either be fully observed or be uncorrelated with $I_{1 s t}$. In practice, researchers cannot measure the commitments made by parties before elections. Moreover, there are reasons for believing that such commitments could be influenced by institutions. For example, the Democrats may adopt a less ambitious tax and spend platform if they know that such policies cannot be implemented in a situation where a supermajority is required for tax increases.

\footnotetext{
${ }^{9}$ Whether $\left(X_{D s t}, X_{R s t}\right)$ actually constrains ex post policy making is an issue of some debate. In the simple Downsian model, it completely determines policy ex post.
} 
While (2) makes an effort to model the policy process (1), many researchers consciously omit $\ell_{s t}$ from this equation to estimate

$$
x_{k s t}=\alpha_{k s}+\beta_{k t}+\omega_{k} I_{1 s t}+\gamma^{k} y_{s t}+\eta_{k s t}
$$

which gives an unbiased estimate of the direct effect of $I_{1 s t}$ on policy outcomes ex post only if $I_{1 s t}$ have no impact on $\ell_{s t}$. Otherwise the estimate of $\omega_{k}$ must be interpreted as the reduced-form impact of $I_{1 s t}$, telling us both about how policy is affected ex post and how the electoral process is affected by $I_{1 s t}$. The latter could happen, for example, if passing a super-majority requirement for tax increases made voters more inclined to vote for a Democrat.

\subsubsection{Elections}

Electoral outcomes are also modeled in reduced-form. Let

$$
P\left(\ell ; X_{D s t}, X_{R s t}, c_{D s t}, c_{R s t}, y_{s t}, I_{2 s t}, H_{s t}\right)
$$

denote the probability that a particular political outcome is $\ell$, when the platforms of the parties are $\left(X_{D s t}, X_{R s t}\right)$, the candidates' characteristics are $\left(c_{D s t}, c_{R s t}\right)$, the history of policy is $H_{s t}$ and the institutions thought to affect the electoral process are $I_{2 s t}$. As outlined above, these institutions include the design and structure of districts, or whether governors face term limits. Relevant candidate characteristics may include policy preferences, such as whether the candidate is pro-choice, and may also include elements of the candidates past reputation.

The role of the variable $H_{s t}$ is potentially quite important and surfaces, in particular, in models of political agency relationships as introduced by Barro (1973) and Ferejohn (1986). This variable could also be expanded to include policies in other states. This would be relevant if yardstick comparisons are made by voters as in Besley and Anne Case (1995a).

In principle, the mapping described by (3) can be studied empirically. Below, we discuss some studies that have done so. Good examples are provided by those studies that model the probability that an incumbent governor is reelected. In this case, $\ell$ is a discrete variable equal to one if the incumbent is reelected. Let $w_{s t}$ be the incumbent's advantage over the challenger, with 


$$
w_{s t}=a_{s}+b_{t}+\zeta I_{2 s t}+\iota y_{s t}+\mu H_{s t}+\rho_{s t}
$$

where $a_{s}$ is a state fixed effect and $b_{t}$ is a year effect. Then we could suppose that

$$
\ell_{s t}=\left\{\begin{array}{cl}
=1 & \text { if } w_{s t} \geq 0 \\
0 & \text { otherwise }
\end{array}\right.
$$

This kind of model can help to pinpoint policies for which the governor is held to account, which are those elements of $H_{s t}$ that influence reelection. It can also be used to see whether reelection rates are dependent on the institutions within a state.

The outcome variable in an election need not be a discrete variable. For example, the variable $w_{s t}$ could be the share of the votes obtained by one of the parties. In that case, we could estimate the empirical model (4) directly.

\subsubsection{Party Strategies}

The mapping from policy pronouncements and candidate choices into electoral success shape the parties' strategies. These can be described both in terms of setting party platforms as in the classical Downsian approach (Downs (1957)) or in terms of candidate choices as in the citizen-candidate approach of Martin Osborne and Al Slivinsky (1996) and Besley and Coate (1997). In reduced-form, let the party preferences induced by (3) be denoted: ${ }^{10}$

$$
W\left(X_{D s t}, X_{R s t}, c_{D s t}, c_{R s t}, y_{s t}, I_{s t}, \chi_{j s t}, H_{s t}\right) \text { for } j \in\{D, R\}
$$

\footnotetext{
${ }^{10}$ These can be thought of as a function of
}

$$
\begin{aligned}
& \left\{P\left(\ell ; X_{D s t}, X_{R s t}, c_{D s t}, c_{R s t}, y_{s t}, I_{2 s t}, H_{s t}\right)\right. \\
& \text { and } \\
& \left.V\left(G\left(\ell, X_{D s t}, X_{R s t}, I_{1 s t}, y_{s t}\right), \chi_{j s t}, y_{s t}\right)\right\}
\end{aligned}
$$

over all legislative variables $\ell$ in state $s$ at time $t$. 
The strategic problem facing parties at election times is to select platforms and candidates to maximize these payoffs. ${ }^{11}$ For the purposes of taking these relationships to the data, it would typically be assumed that a Nash equilibrium exists and is unique. ${ }^{12}$ The outcomes are now party platforms and candidate lists.

In principle, this part of the process is amenable to empirical testing when sufficiently detailed data on candidate composition and party platforms are available. There are clearly interesting issues here, such as the effect of primary rules on candidate composition, and the effect of campaign contribution restrictions on candidate selection and party policy. However, to date the literature has not studied these issues.

\subsubsection{Political Outcomes}

Given a set of party strategies, the electoral process (3) gives rise to a particular realization of $\ell_{s t}$. Key measurable components of this include the strength of Democratic party representation in the upper and lower houses, and the fraction of women elected. This could be modeled empirically for the $k$ th political outcome, as follows:

$$
\ell_{k s t}=\zeta_{k s}+\xi_{k t}+\lambda^{k} I_{s t}+\phi^{k} y_{s t}+\nu_{k s t}
$$

where $\zeta_{k s}$ is a state indicator, $\xi_{k t}$ is a year indicator. The exact choice of the institutional vector to be included can be determined pragmatically. As we observed above, this may include institutions that are thought to primarily have an impact on ex post policy making $\left(I_{1 s t}\right)$ as well as those that affect the election process $\left(I_{2 s t}\right)$.

The reduced-form relationship may, by itself, be interesting to analyze. However, it is clear that interpreting the sources of influence in the reducedform relationship (7) could be quite difficult. For example, a link observed

\footnotetext{
${ }^{11}$ It is useful to note that this approach encompasses within it the standard Downsian approach to policy competition where the choice of candidates is irrelevant - policy is determined ex ante with full commitment. It also includes a Lindbeck and Weibull (1993) type of model. It also encompasses the approach suggested in Besley and Coate (1997), (2000a,b) where competition takes place by proposing candidates with different characteristics.

${ }^{12}$ It is well known that this is not a trivial matter. Here, it would require sufficient smoothness and concavity assumptions on the payoff function and the function that maps policies into number of seats.
} 
between the fraction of women in the legislature and the rules that govern campaign finance could be working through a change in the candidate composition or through a change in the probability that women candidates are elected.

In (3), political outcomes were allowed to depend on political and policy history. However, in the empirical work to date, estimation of (7) has rarely included history variables. In principle, this could be done by estimating

$$
\ell_{k s t}=\zeta_{k s}+\xi_{k t}+\lambda^{k} I_{s t}+\phi^{k} y_{s t}+\kappa^{k} H_{s t}+\nu_{k s t}
$$

In practice, $H_{s t}$ can be represented by lagged policy and political control. Issues arise if these are not strictly exogenous, if for example there were long lasting shocks to policy preferences. Short panels also present problems, if $H_{s t}$ includes predetermined by not strictly exogenous variables.

A wide variety of legislative outcome measures have been discussed in the existing literature. Part of our task is to look at a consistent set of outcomes with a common method, and we have chosen to study the following outcomes in this essay:

- Legislative outcomes: Characteristics of state office holders, including the fractions of Democrats in the state house and senate; party affiliation of the governor; the fraction of women representatives in the upper and lower houses; the ideology of the state government; voter turnout; and the degree of party competition.

\subsubsection{Policy Outcomes}

The model that we have spelled out gives a sense of the rich variety of routes by which policy can be affected by institutions. However, it isolates two main routes: directly, through the ex post policy process (1), and indirectly, through the ex ante electoral process (3). As we have already discussed, isolating the latter empirically may not be easy. That the party preferences induced by the electoral and policy process, (6), depend on both sets of institutions could imply that party strategies respond to institutional change. This makes identification of the source of influence difficult.

For this reason, a fully reduced-form approach is often chosen, in which no effort is made to isolate the chains of influence. In this case, the model is: 


$$
x_{k s t}=\alpha_{k s}+\beta_{k t}+\omega_{k} I_{s t}+\gamma^{k} y_{s t}+\eta_{k s t}
$$

where $I_{s t}$ contains the full institution vector. In fact, most studies that we discuss are much more piecemeal in their approach and tend to include only a small set of institutional variables in the analysis, typically those in $I_{2 s t}$.

Again, history is generally overlooked in the estimation of policy equations. This need not be the case, and one could estimate

$$
x_{k s t}=\alpha_{k s}+\beta_{k t}+\omega_{k} I_{s t}+\gamma^{k} y_{s t}+\tau_{k} H_{s t}+\eta_{k s t} .
$$

The variable $H_{s t}$ could again include lagged policy and political controls, raising similar econometric issues to those that arise in estimating (8).

There is a wide variety of policies that can be studied, as the literature we discuss below makes clear. For our empirical work, we focus on the following narrower set of policy outcomes to comprise the $x_{s t}$ :

- Policy outcomes: Total state income, sales and corporate taxes per capita; state expenditures per capita, both in total and disaggregated to focus on redistributive expenditures (such as family assistance and workers compensation).

\subsection{Institutional Change}

Institutions change over time. This is more easily dealt with theoretically than in empirical applications. One possibility is that electoral and decision making institutions are chosen strategically to affect future election outcomes. This draws a parallel between the literature on institutional change and strategic policy making as developed, for example, in Tabellini and Alesina (1987) and Persson and Lars Svensson (1989). In such models, an incumbent chooses to constrain future policy makers by changing the level of public debt that they inherit. There are cases where this Machiavellian theory of institutional change would seem relevant (at least anecdotally). A good example is the case of decentralization. In the U.K., Tony Blair's increased decentralization will result in a counterweight to the power of the Conservative party. It may also make it less likely that the Conservative party will win office in the future. Republican efforts to decentralize welfare policy in 
the United States could also be viewed strategically as an effort to encourage a race to the bottom with a resultant reduction in welfare spending.

At the core of any strategic theory of policy making are preferences defined over institutions. In terms of the theoretical approach discussed here, consider

$\widehat{W}\left(y_{s t}, I_{s t}, \chi_{j s t}, H_{s t}\right)=W\left(X_{D s t}^{*}, X_{R s t}^{*}, c_{D s t}^{*}, c_{R s t}^{*}, y_{s t}, I_{s t}, \chi_{j s t}, H_{s t}\right)$ for $j \in\{D, R\}$

where the $*$ denotes that we are considering the equilibrium values of platforms and candidate choices which themselves depend upon institutions and other exogenous variables.

Suppose that a party is in office and, by incurring some costs, could change the institutions that affect future payoffs. Then its choice of optimal institution will be

$$
I_{j s t}^{*}=\arg \max _{I_{s t}}=\widehat{W}\left(y_{s t}, I_{s t}, \chi_{j s t}, H_{s t}\right) .
$$

It is clear that there could be differences in the different parties' support for particular institutional changes, just as there are differences in their policy preferences.

In practice, there are many factors that create inertia in the reform of institutions. Some of the institutions that we consider require elaborate processes of institutional change, including judicial review and constitutional amendments. A good example concerns the institutions that affect campaign finance in the U.S.. These have been affected by Federal legislation and by the way in which the Federal Supreme Court has interpreted their boundaries vis a vis the right to free speech.

From the standpoint of empirical modeling, institutions can be modeled in the same way as policy and legislative outcomes. Consider the following equation:

$$
I_{e s t}=\alpha_{e s}+\beta_{e t}+\gamma_{e} H_{s t}+\sigma_{e} w_{s t}+\omega_{e s t} .
$$

History $H_{s t}$ may well now include the history of $I_{s t}$, and $w_{s t}$ includes(potentially time-varying) state level variables thought to explain the specific institutional change in question. 
Problems arise in estimating the impact of institutions on policy or political outcomes when the determinants of institutional change are correlated with the error terms in either of equations $((2),(7)$ or (9) above). This is more likely to be of concern in cross-sectional studies than in panel data studies. It may be plausible in many instances to think that the variables $w_{s t}$ are not time varying and hence could be absorbed in state fixed effects. Good examples are long-run variations in political culture across states. Authors of cross-sectional studies or a panel data studies that omit fixed effects have to assume that there are no time-invariant omitted regressors that drive institutional choice.

\subsection{Summary and Outline}

To summarize, there are five main theoretical relationships suggested by the theory:

- The effect of policy making institutions $I_{1 s t}$ on the ex post policy process as represented by equation (2).

- The effect of institutions $I_{2 s t}$ on the electoral process as represented by equation (4).

- The effect of institutions (mainly electoral institutions $I_{2 s t}$ ) on political outcomes as represented by equation (7).

- The effect of institutions, $I_{s t}$, on policy as represented by the equation (9).

- The process determining institutional change as represented by equation (11).

Discussion of the theoretical components underscores the point that the institutions that affect the policy process through (1) and those that affect the electoral process (3) may not be easy to separate, once the strategies employed in the political process are recognized. This has implications for the interpretation of the results that we discuss below.

The remainder of the paper is organized around looking at specific examples that study one or other of these relationships. In section 5, we study legislative outcomes as a function of institutions along the lines of (7). 
Section 6 examines (2), with a particular focus on how $\ell_{s t}$ enters this relationship. Section 7 looks at a variety of empirical models representing (2) and (9). It also considers the process of electoral accountability. Section 8 discusses studies based on equation (11).

One of the contributions of this paper is to estimate relationships discussed in the literature. To do so, we have assembled a cross-state panel data set for the 48 continental U.S. states from 1950-99. While not all variables are available for the entire study period, many are. Of the studies that we review, many use shorter time periods - often for the obvious reason that they were written some time ago. However, a variety of empirical methods are also at large in the literature. Where possible, we identify the relationships that we seek from a baseline model that includes state and year fixed effects. ${ }^{13}$ We believe that this provides credible estimates for many of the relationships in question.

The above specification assumes that there is time series and cross-sectional variation in the institutional variables $\left(I_{s t}\right)$. In many cases discussed below, researchers are interested in studying the impact of institutions that do not vary over time. Then, the above model is not estimable. Such studies usually proceed either in cross-section or by omitting the fixed effects, hoping that $x_{s t}$ will capture the relevant heterogeneity over the cross-sectional units. For this to be a satisfactory way of estimating the impact of institutions on outcomes, we need to assume, in the usual way, that $\eta_{s t}$ is uncorrelated with the institution in question. This is often a very strong assumption.

An alternative way to get mileage out of fixed institutions is to derive (preferably from some underlying theoretical structure) their implications for the response of an outcome to a time-varying regressor. For example, Besley and Coate (2000a) consider the effect of electing versus appointing regulators on the relationship between cost and price. If such implications exist, one can exploit the panel nature of the data even where there is only cross-sectional variation in institutions.

The fixed effects, in particular, are crucial to dealing with long-lasting unobservable differences between states that affect both institutional rules and fiscal outcomes. It will not surprise the reader that many of the (unreported) specifications that do not include state fixed effects yield dramatically different results. When fixed effect estimation is not possible - when, for example,

\footnotetext{
${ }^{13}$ Results presented below are largely robust to estimation using state and year effects and robust standard errors.
} 
the policy in question varies by state, but not over time - we estimate robust standard errors, allowing for an unspecified form of correlation between observations from the same state over time. (Although, below, we discuss cases where robust standard errors may not be appropriate. See Section 7.1) We believe it important that a common method of estimation be used across the specifications that we report, to allow the results to be read as all being cut from the same piece of cloth. Differences in methods of estimation are an important potential source of discrepancy between results in the literature.

\section{Institutions, Politics and Policy in the States}

Our study uses data from the 48 continental states for the post-war period. The background against which institutional features will be highlighted is the growing importance of state governments over this period, especially in taxing and spending. In 1950, state governments took on average $3 \%$ of state income in taxes, a percentage that roughly doubled in fifty years, rising to $5.7 \%$ by 1999 . US states had tax revenues of $\$ 161$ per capita on average in 1950, which climbed to $\$ 833$ per capita in 1999 (all measured in real 1982 dollars). ${ }^{14}$ The same story holds true on the expenditure side. State spending rose from an average of $6.9 \%$ of state income in 1950 to $12.4 \%$ in 1999 . This constitutes an increase from $\$ 370$ to $\$ 1764$ per capita in real terms. No single factor led to this dramatic change, just as no convincing mono-causal force has been identified behind Wagner's law, in the vast literature on this. ${ }^{15}$ Table 4.1 presents data from the decennial census years, unless otherwise noted, to provide some sense of the pattern in the data over time. The change in magnitude of state government can be seen in the fourth panel, which presents average state tax revenues and state spending per capita. In the empirical work that follows, we analyze annual data from 1950 to 1999 where possible. Some of our data series begin later. Detailed data from the Center for the American Woman in Politics, for example, publishes data on women legislators only from 1975 to the present.

Aggregate tax revenues and expenditures provide only a crude look at the changes observed. Within taxes, the most striking finding is the growth

\footnotetext{
${ }^{14}$ Unless otherwise stated, dollar values in the empirical work that follows will be given in 1982 dollars.

${ }^{15}$ See Cheryl Holsey and Thomas Borcherding (1997) for a review of the issues with a US focus.
} 
in income and sales taxes. In 1950, 17 states raised no income taxes. By 1999, all but 6 of the continental states had an income tax. The picture is similar for the corporate tax - 18 states were without one in 1950, true of only 3 or 4 states in 1999 (depending on how one characterizes the "franchise tax" on earned surplus in Texas). Substantial changes also occurred over this period in the distribution of government spending. Family assistance per capita tripled between 1960 and 1980 (fourth panel, Table 4.1). Since that time, it has fallen in real terms, particularly in the second half of the 1990s. In contrast, state spending on workers compensation has increased monotonically since 1950 .

Over this period, there has been a reasonable amount of institutional change. All fifty US states have broadly similar constitutions with a bicameral system (Nebraska is an exception here) and an elected governor. However, there is significant variation in electoral processes between states, with differences in the way states organize their legislative districts, and in the way registered voters go about voting for candidates. States also vary in their campaign-finance laws, and voter registration and party primary rules. Some of these differences are highlighted in the first panel of Table 4.1. In 1950, 7 Southern states (roughly 15 percent of states in our sample) had poll taxes, which restricted voting among the poor, and roughly 14 percent of state residents were affected by a literacy test, a device that severely limited the ability of less well-educated people, or those whose command of English was poor, to vote. These voting restrictions were eliminated in the 1960s, but voter registration continued to be restricted by regulations on place of registration, the timing of registration relative to the next election, and the continuation of a place on the voting rolls for those who missed elections. With the passage of the National Voter Registration Act (NVRA) of 1993 (the "motor-voter act"), voter registration through vehicle registration is currently becoming a reality in all but a handful of states. States that were flexible in allowing registration on polling day or that required no registration (MN, ND, WI,WY, NH, ID) were exempt from the NVRA. The fraction of states in compliance with NVRA, and those with flexible registration, has increased over time, as can be seen in the first panel of Table 4.1.

There has been much variation over time and between states in the types of primaries parties have run, with the fraction of states running open primaries doubling between 1960 and 1990. Another important institutional restriction is the ability of governors and state legislators to stand for reelection. In the 1990s alone, 10 states passed term limits on the number 
of terms their governors can hold successively and, by the end of the 1990s, three-quarters of all the continental US states had some sort of gubernatorial term limit.

Once elected, officials face different constraints on what they can do. For example, there are differences between states in tax-setting power, and on whether the governor possesses a line-item veto. There are also important differences between states in the scope of policy responsibility. For example, some states directly elect certain office holders while others allow the governor or legislature to choose them. The responsibility of different elected officials may also vary.

These political institutions may affect outcomes directly - for example, super majority requirements may have a direct effect on tax rates. In other cases, these institutions may affect policy choices through their effect on the character of the legislature. The fractions of seats in the states' lower and upper houses that are held by Democrats, or the number of women elected to the legislature, may depend upon electoral rules. The middle panel of Table 4.1 shows that the proportion of seats held by women rose in the second half of our sample period, and that the proportion of seats held by Democrats varied substantially from decade to decade, with the fraction of seats in the lower house as high as 70 percent in 1960 and as low as 55 percent in 1970 . To the extent that these swings are due to macro shocks that affect all states (the Vietnam War, for example), their movements will be absorbed in year effects included in all regressions. Contemporaneous state-by-year movement in institutional rules and, say, the fraction of seats held by Democrats will then be attributed to the institutional change.

An important feature of parties is the way in which they generate competition for political office. There is a view, perhaps most famously articulated by Valdimer Key (1950) that parties are likely to be most effective as a representative mechanism when they are in a truly competitive environment. There is no unanimously agreed method of measuring this. Authors have variously used differences in seat or vote shares at the last election as a means of quantifying the extent of competition between the parties. Table 4.1 uses a very simple measure of party competition equal to -1 times the absolute difference from 0.5 in the fraction of seats held in the lower house by Democrats times the absolute difference from 0.5 in the fraction of seats held by Democrats in the upper house. In this way, larger (less negative) numbers are associated with more competition - that is, with a closer balance in seats 
between the two parties. ${ }^{16}$ Table 4.1 suggests that party competition in state legislatures has risen through time.

The final panel of the table contains information on some of the timevarying state-level controls we will use in the empirical work presented below. States became significantly wealthier over this period, with real state income per capita more than doubling between 1950 and 1990. State populations have become older on average as well, with the proportion aged 65 and above rising from 8.1 percent to 12.7 percent, and the proportion that is school aged falling from 21.5 percent to 18.9 percent. It is anticipated that these income and demographic changes will move states' political and policy choices.

While the U.S. is broadly a two party system, there are differences in the political complexion of the parties in different states. Thus the political scientists Erickson, Wright and McIver (1989) observe that "the Democratic party of Mississippi is far more conservative than the Democratic party of New York and perhaps the New York Republican party as well." (page 731). Several measures of the ideology of the citizens and parties in different states have been developed. Berry et al (1998) construct measures of state citizen ideology from widely used ideology ratings of the state's Congressional delegation. ${ }^{17}$ These are the Americans for Democratic Action (ADA) rating, and the AFL/CIO's Committee on Political Education (COPE) rating. Berry et al assign an ideology rating to the citizens of each Congressional district using a weighted average of the Congressional member's score and his or her election opponent's score, weighting the scores according to the number of votes each received. They then generate a state-wide measure by taking the simple average over all Congressional districts. Berry et al also construct a measure of government ideology, by assigning to the governor and major party delegations in the legislature the ratings of the members of Congress from their party. Table 4.1 suggests a move toward a more conservative ideology in the middle years of our period (roughly 1980), followed by a return to a slightly more liberal stance in the $1990 \mathrm{~s}$, as measured by the citizens'

\footnotetext{
${ }^{16}$ Our definition of competition is related to, but distinct from, the fraction of seats in the upper and lower houses held by Democrats. As the fraction held by Democrats in lower house increases from 0 toward 0.5 , both fraction Democrat and our competition measure will increase. However, when fraction Democrat increases from 0.5 toward 1.0, the fraction Democrat obviously increases while, ceteris paribus, our measure of competition falls.

${ }^{17}$ There is a large political science literature on measuring ideology of citizens and elected officials. Berry, Ringquist, Fording and Hanson (1998) for provide a useful review of the various methods used to construct these, as well as new data.
} 
COPE scores.

The literature has long recognized that differences exist in institutions, ideology, and legislative and policy outcomes between states in the Southern region of the U.S. and elsewhere. We take a second look at our institutional and outcome variables in Table 4.2, where for 1960 and 1990 we present means for the US South and for all other parts of the U.S. In the early part of our sample, it is clear that the South restricted access to the vote: it was the Southern states that relied on poll taxes and literacy tests in the 1950s and early 1960s. In 1960, Southern states were also significantly less likely to hold open primaries, or to allow citizens' initiatives. Southern states in all parts of our sample have significantly higher fractions of Democrats in both the lower and upper houses of their legislatures. In the early part of the period, their governors were significantly more likely to be Democrats - but were also significantly more conservative. This was true of citizens in Southern states as well, measured using the COPE score. Voter turnout is significantly lower in the South (in part as a result of the restrictions on registration and voting), as is party competition in the legislature, perhaps as a result. Southern states are also less affluent, measured using state income per capita. In the estimation results we present below, we do not generally rely on the level-differences between states - because our estimation strategy generally includes state fixed effects. To the extent that Southern states have changed their institutions and legislative composition over time, these changes help to identify the results we present below.

Overall, it is clear that there is both interesting institutional, political and economic variation in the US states, both across space and time. This provides the core of the empirical exercise that follows.

\section{$5 \quad$ Institutions and political outcomes}

In this section, we consider how institutions affect political outcomes. The main institutions of interest in this section are those that govern voter registration, candidate selection (primary rules), legislative redistricting and campaign finance. We examine their association with measurable political outcomes - such as party control, political competition and ideology. From a theoretical point of view, these exercises can best be thought of as getting an empirical handle on (3), while bearing in mind that the institutional effect may be working through the choice of candidates $c_{j s t}(j \in\{D, R\})$ as well as 
through the process by which a given candidate is elected.

\section{$5.1 \quad$ Voting}

If voting is an effective mechanism for determining policy outcomes, then it requires that individuals show up at the polls to express their views. This has two parts. First, whether individuals have registered to vote and second, whether registered voters turn out on election day. As we noted in section 4, there are important institutional variations in the way in which states organize voter registration. There are good reasons to expect that these will affect registration and hence turnout.

While some political scientists view turnout as a good in itself - signaling the health and legitimacy of a democracy - it is less obvious whether turnout affects policy outcomes. This depends on whether there are important sources of bias in turnout, in the sense that low turnout favors one party over another. It is widely known that turnout varies across different groups in society, ${ }^{18}$ with richer and better educated citizens more likely to vote. There is a long-standing view in political science that biases in turnout bias policy choices - the main expectation being that larger turnout among low income groups will be correlated both with better election performance by the Democrats and with more redistributive policies, as the income of the decisive voter falls. This mechanism is key to some recent papers, such as Roland Benabou (2000).

Kim Quaile Hill, Jan Leighley and Angela Hinton-Andersson (1995) look at whether increased voting changes policy outcomes, by increasing the representation of low income interests. Using panel data from 1978-1990, they find that turnout among lower-class voters is positively associated with increased welfare spending. This is robust to year effects, although they do not include state effects. However, using turnout as a regressor is problematic, since it is likely to be determined by some of the same unobservable factors that drive policy. For example, it is possible that some information about the economy is revealed, information that leads both to higher desired

\footnotetext{
${ }^{18}$ The classic study in political science is Raymond Wolfinger and Steven Rosenstone (1980). They, and a host of subsequent researchers, estimate the effects of voter registration laws using micro data with turnout as the outcome variable. They then interact these laws with socioeconomic information about individuals, finding that registration laws have the most bite for low education groups.
} 
welfare spending and to more people turning out to vote. ${ }^{19}$

A promising approach to estimating the impact of turnout on policy choice is to find institutional change that affects registration and turnout independently of the demand for policy. In recent US history there are three reforms that have affected the probability that citizens will register to vote. First, in the early part of the century, many states were forced by the Federal government to extend the franchise to women. Second, changes to voting rights laws in the 1960s and 1970s led to greater registration by minority voters. More recently, states have encouraged voter registration under so-called "motor-voter" laws that tie vehicle license registration to voter registration. For all of these institutional changes, a strong case can be made that the changes were driven by a desire to protect citizens' rights, and not by a desire to change legislative outcomes.

John Lott and Lawrence Kenny (1999) consider the effect of extending the franchise to women, using data from 1870 to 1940. They exploit the fact that some states gave women the vote before it was Federally mandated in 1920, which generates state-to-state variation in the timing of women's suffrage. They find that women's participation increased the size of government. While the finding is interesting, they offer no theoretical explanation, but suggest that it may be due to the different policy priorities of men and women vis a vis child rearing issues. ${ }^{20}$

Thomas Husted and Kenny (1997) consider the effect of the Federal voting acts of the 1960s and 1970s, which struck down literacy requirements and poll taxes. As we discuss in greater detail below, they find significant correlations with welfare spending. Earlier work by John Filer, Kenny and Rebecca Morton (1991) found these acts to have had a significant impact on turnout.

The ease with which voters may register has also been studied as a source of difference in voter turnout (see Benjamin Highton (1997) for a review of the political science literature). One of the key institutional variations that has been studied is whether voters can register on election day. Suggestively, Highton, using data from 1980 and 1992, finds that turnout is $10 \%$ higher in North Dakota (where no voter registration is required) and other states with election day registration. The biggest difference in turnout appears among those with low levels of education.

\footnotetext{
${ }^{19}$ See Timothy Feddersen and Wolfgang Pesendorfer (2000) for a particular example of this.

${ }^{20}$ Lena Edlund and Rohini Pande (2001) look at how changing family circumstances in the U.S. have changed the voting patterns by gender in the post-war period.
} 
Arguably, studying these institutional changes provides a more satisfactory basis for assessing whether who votes affects policy outcomes than does simply controlling for turnout in a reduced-form regression. Moreover, there is both cross-sectional and time-series variation to exploit, as some states changed their laws without prompting from the Federal government.

Table 5.1 examines the impact of a variety of institutions on voter turnout. Specifically, we examine whether literacy tests and poll taxes, voter registration, citizens' initiatives, and restrictions on corporate campaign financing affect voter turnout, while controlling for year effects and a number of timevarying state level variables that may affect turnout (state income per capita and income squared, state population and population squared, the proportion of the population aged 65 and above, and the proportion aged 5 to 17). Turnout is defined here as the number of votes cast for the highest office holding an election in that year divided by the total voting age population in the state. The impact of literacy tests and poll taxes on turnout is immediately apparent in column 1 of Table 5.1. Consistent with the results of Filer, Kenny and Morton $(1991,1993)$, voter turnout was roughly 15 percentage points lower on average in states when poll taxes were in place. Because we control for state fixed effects, the impact of poll taxes is identified using turnout information from states that ever had a poll tax, by calculating differences (state-by-state) in turnout, before and after the poll taxes were lifted.

Turnout is positively correlated with having a constitution that permits citizens' initiatives: turnout is on average 3 percentage points higher in states where initiatives are allowed by law. This is consistent with the often articulated view among political scientists that direct democracy promotes political participation (see, for example, David Butler and Austin Ranney (1978)). However, there is very little time-series variation in our initiative variable, and this regression does not include fixed effects. Hence, the result could be due to some state-specific omitted variable such as "political culture" that drives initiatives and voter turnout.

States with the least cumbersome voter registration - either allowing registration on polling day, or not requiring registration at all - have voter turnout that is roughly 2 percentage points higher on average (although the effect is only marginally significant when all controls are included in column $5)$. We find no impact of motor-voter registration on voter turnout - the effects are small and never significantly different from zero. Perhaps states that turned to motor-voter registration early on were those where it was most 
difficult to encourage people to vote.

Voter turnout is significantly correlated with restrictions on corporate campaign contributions. Controlling for state fixed effects, in those states that adopted restrictions on corporate campaign contributions, turnout was 2 percentage points higher (a point we return to below). These results are robust to estimating the impact of poll taxes, literacy tests, voter registration and corporate campaign finance requirements simultaneously (column 5), where these institutional rules are jointly highly significant $(F$-test $=66.09$, $\mathrm{p}$-value $=.0000)$.

That institutional rules may also affect the political composition of the legislature is clear from Table 5.2, where we regress three outcome measures - the fraction of the seats in the states' upper houses held by Democrats, whether the governor is a Democrat, and measures of party competition on indicators that the state has a poll tax, a literacy test, voter registration through vehicle registration, day-of-polling registration, and an indicator for restrictions on campaign contributions. We control for state and year effects and the same time-varying state-level controls introduced above. In Table 5.2 , all controls have been lagged one period, to represent conditions in the state in the year in which these office-holders were elected.

We find that literacy tests protected the seats of Democrats in those Southern states that had these restrictions on voting. The effects of poll taxes and literacy tests are identified from the timing of the changes in state laws relative to the timing of changes observed in the composition of the legislatures. The relationship between the two can be seen most clearly in Figure 2, which displays the fraction of seats in state upper houses held by Democrats in four of the five states that had literacy tests in the 1950s and early 1960s. These tests were eliminated with the 1965 Voting Rights Act, a point in time marked in Figure 2 by the vertical line. ${ }^{21}$ In three of these states (LA, MS, SC), 100 percent of seats in the state upper house were held by Democrats until 1965. Starting in 1966, Democratic control began to erode. The fourth state (VA) begins with a slightly lower fraction Democrat (95 percent), and Democratic control erodes from this lower initial level. That this is not simply picking up the general movement away from the Democratic party in the South can be seen by comparing results for these states with those for states that did not have literacy tests. Erosion of

${ }^{21}$ The fifth state, Georgia, looks very much like these four, but is not shown in order to make it easier to follow the changes across the states over time. 
Democratic control in the latter does not match the pattern seen in Figure 2. In Kentucky and Tennessee, for example, erosion began in the 1950s while, in Alabama and Arkansas, it did not begin until the 1980s. ${ }^{22}$

Poll taxes and literacy tests kept turnout low, and the fraction of Democrats in the legislature high. This negative association between turnout and the fraction of Democrats elected may be special to the South in the 1960s. These restrictions stopped minority voters from going to the polls in Southern states, where protest votes or votes for change would be votes for the Republican party. Thus, once enfranchised, minority voters in the South lessened the Democrat's stranglehold on the state houses. Elsewhere, institutions that increased turnout appear to act as the literature suggests, with increased turnout giving way to an increase in Democratic representation. Day-of-polling registration has a positive effect on turnout (see Table 5.1), and is associated with an increase in the fraction of seats held by Democrats. Restrictions on corporate campaign contributions are also associated with both higher turnout and with a higher fraction of the states' upper houses held by Democrats: on average, if a state passes restrictions on corporate contributions, the share of the state upper house that is held by Democrats increases by 2.1 percentage points. Jointly, these institutional rules are significant correlates of house composition $(F$-test $=4.47, p$-value $=.0005)$. $($ Results are quite similar when the proportion of Democrats in the states' lower houses is regressed on these same controls.)

The institutional rules we have identified here also have significant effects on party competition in the legislature (columns 4 and 5). Whether rules that systematically favor one party strengthen competition in the legislature depends upon the initial legislative composition. Thus poll taxes, literacy tests, and day of polling registration weaken competition, in general improving the position of Democrats in legislatures where Democrats are strong. In contrast, restrictions on corporate campaign contributions increase competition by improving the position of Democrats in states where Democrats are less likely to hold majorities in the state houses. ${ }^{23}$

\footnotetext{
${ }^{22}$ Details are available from the authors on request.

${ }^{23}$ For example, Maine limited corporate campaign contributions beginning in mid-1970s. Prior to that, Democrats were a minority in the state upper house. Averaged over all years from 1950 to 1975, Democrats held 29 percent of seats in the upper house. After the imposition of corporate restrictions, averaged over all years from 1976 to 2000, Democrats held 54 percent of seats in the upper house. Regression results in Table 5.2 are based on this sort of calculation (while allowing for year effects and state-level time varying
} 
While these institutional rules have a large and significant effect on the state legislatures, they appear to play little role in the election of a governor. None of the institutional controls is significant by itself, nor are they jointly significant. This may indicate the greater relative importance of idiosyncratic personality factors in gubernatorial elections.

As we have seen above, turnout is significantly correlated with these election rules but, interestingly, the impact of institutional rules on the party composition of the legislature does not work through voter turnout. When we include a control for turnout (column 2), it has no significant effect on the fraction of the upper house held by Democrats, and has no effect on the coefficients attracted by the electoral rules. (Neither is the turnout variable significant when the institutional rules are omitted as controls.) Where turnout appears to have a significant effect on the legislature is in the degree of party competition (column 5). In those years in which turnout is large, the legislature becomes more evenly divided between Republicans and Democrats. The insignificant association of turnout with the fraction of seats held by Democrats, given the significant association with competition in the legislature, merits further discussion. Turnout may keep the fraction of Democrats close to 0.5 , which here is registered as increasing competition. However, this does not imply a monotonic relationship between turnout and the fraction of seats going to Democrats. If the fraction held by Democrats is above 0.5, increased turnout appears to bring the fraction down. Alternatively, when the fraction is less than 0.5 , turnout pulls the fraction up.

For each dependent variable, we can test whether institutional rules are affecting legislative composition solely through their effect on turnout. In the third column, we present results for instrumental variables estimation, where voter turnout is instrumented on the institutional rules that appear in columns 1 and 2. The $F$-test in column 3 compares the fit of the regression that uses the predicted value of turnout in column 3 to that in column 1 , where the institutional rules are allowed to enter in an unrestricted fashion. Results in column 6 report an analogous comparison for party competition in the legislature. We reject that these institutional rules are affecting the fraction Democrat and party competition solely through their effect on voter turnout.

Overall, results in this section provide evidence that institutional variables have real effects on legislative composition and competition, only part of

controls). 
which can be explained by their impact on voter turnout.

\subsection{Primaries}

Institutional rules may also affect who is selected to run for office. The main vehicle for candidate selection is the primary process, and there are important differences in primary rules across states. Models of electoral competition that include primaries typically divide the action into three stages. At stage one voters affiliate themselves with a particular party. At stage two parties nominate some to run for office from among the subset of candidates that choose to stand. At stage three voters choose between party nominees.

States vary in the primary rules that they use to determine candidate choices. There are basically two institutional variants. In open primaries, participants do not need to declare their party allegiance in advance of the primary. ${ }^{24}$ In closed primaries, participation is limited to voters who have declared a party affiliation a sufficient time prior to the primary. ${ }^{25}$

Elisabeth Gerber and Morton (1998a) argue that more open primary arrangements will likely lead to more moderate candidates being chosen. Closed primaries restrict influence to the party elites, who are more likely to have strong ideological preferences. By facilitating cross-over voting (i.e., for a party with whom one does not identify), open primaries will tend to lead to more moderate candidates being selected (although Gerber and Morton observe that things are less clear cut if cross-over voting has a strategic element). They cite a significant number of political science studies suggesting that cross-over voting is more common in more open primaries. To look at this empirically, they examine the ideological stances of winners in Congressional races. They use past voting records in Presidential races as a control for the ideology of the districts, and argue that the evidence is consistent with their hypothesis that more open primaries spawn less extreme candidates. ${ }^{26}$

We examine the impact of primary rules on political outcomes in Table 5.3. The first two columns provide evidence on the relationship between

\footnotetext{
${ }^{24}$ Within this general category are blanket primaries, where voters may participate in all parties' primaries. In non-partisan primaries, voters choose among candidates without declaring any party allegiance.

${ }^{25}$ Primaries are semi-closed if new registrants can register for a party on the day of the primary or if independents are allowed to participate.

${ }^{26}$ Gerber and Morton (1998b) examines the effect of primary rules on how inclusive the parties are likely to be in forming electoral coalitions.
} 
open primaries and voter turnout for the highest office holding an election in that year. Data are available for the even years between 1950 and 1998. We find that open primaries are positively related to voter turnout, increasing turnout by 1 to 2 percentage points. When controls are added for other institutions related to turnout, open primaries are a significant determinant of turnout (column 2).

Open primaries are not significantly related to the party-composition of the legislature (columns 3 and 4). However, open primaries are negatively correlated with the fraction of women elected to state lower houses (columns 5 and 6). Again, because state fixed effects are included in each specification, this effect is identified using changes in the election of women legislators within states that changed their primary rules during the period 1977 to 1999, which occurred for half of all US states. This finding could signify that party elites are more keen on women's representation than are voters at large. However, it clearly requires a more thorough-going investigation. It also raises the issue of what motivated changes in primary rules in the states that implemented them - a theme that we return to in section 8 below.

In the spirit of the discussion of Gerber and Morton (1998a), we also test whether open primaries reduce the ideology gap between citizens and their elected officials. To do so, we first generate measures of this gap using data from Berry, Ringquist, Fording and Hanson (1998). We find that open primaries are associated with reductions in the absolute differences between the ideologies of citizens and elected officials, measured using their COPE scores (columns 7 and 8). In line with the findings of Gerber and Morton (1998a), this suggests that open primaries may have a systematic effect on political representation, perhaps being indicative of greater empowerment of less ideologically motivated voters.

\subsection{Campaign Finance}

Campaign finance reform has been a major political issue of late, given a general popular concern about the level of political spending. It is estimated, for example, that more than $\$ 3$ billion were spent on political campaigns in the year 2000 elections. ${ }^{27}$ Current campaign financing rules raise many difficult issues, including the possibility that public officials may become beholden to special interests, and that the sums of money necessary to launch a cam-

\footnotetext{
${ }^{27}$ Public Campaign, www.publicampaign.org.
} 
paign may discourage able challengers, to the benefit of incumbents. Steven Levitt (1995) takes a more sanguine view, at least for Congressional elections, suggesting that the most careful recent studies have not found spending by challengers to be more effective than that of incumbents and that, for this reason, placing limits on spending will do little to alter the incumbency advantage. In addition, Levitt reviews work that questions whether Political Action Committees (PACs) have much of an effect on elected officials' behavior once in office. The history of campaign finance reform, details of the current laws and innovations in the states is provided in Anthony Corrado, Thomas Mann, Daniel Ortiz, Trevor Potter and Frank Sorauf (1997).

John Lott (2000) looks at the recent history of campaign spending in the US states, and finds that gubernatorial real per capita campaign spending rose by 58 percent between 1982 and 1990 in those states that held elections in 1982, 1986 and 1990, and by 62 percent in those that held elections every four years from 1980 to 1992 . Using data on state house and senate races for sixteen states over various periods for which data were available, and gubernatorial races for the period from 1977-94, and controlling for both state fixed effects and year effects, Lott finds that state per capita expenditure is a close predictor of the level of campaign spending. In addition, open seats for governor attract higher levels of spending.

There has been a great deal of variation across states and over time in the administration and enforcement of campaign finance laws. Robert Huckshorn (1985) discusses variation across states in four types of finance regulations: spending limits by candidate; contribution limits by different types of supporters (corporations, unions, individuals); disclosure rules; and monitoring and enforcement mechanisms to stop illegal or unethical expenditures. Differences across states creates a source of institutional variation that may have political ramifications. As well as creating an interesting source of institutional variation for political testing, the theoretical consequences of these institutional variations are of interest. They may, for example, affect the kinds of candidates who are selected, as in Coate (2001). By changing the provision of information, campaign finance can also affect voter attachment to particular parties or candidates. ${ }^{28}$

While there is a large body of work examining the impact of campaign spending in federal elections, explorations of the empirical effects of campaign

\footnotetext{
${ }^{28}$ For an overview of the issues on campaign finance reform, see Morton and Charles Cameron (1992).
} 
finance laws at the state level are extremely sparse. Lott (2000) reports that limits on donations and outright bans have statistically significant effects on campaign spending in his regressions. Thomas Stratmann and Francisco Aparicio-Castillo (2001) use the competitiveness of state house races as their outcome variable to examine the empirical consequences of campaign finance laws, in state fixed effect models using data on forty-five states for the period 1980 to 1999. Focusing on regulations that affect individual contributions, they find that contribution regulations hold down incumbents' vote shares.

Our empirical results focus on limits placed on corporate campaign financing and their effects on turnout, Democratic control, and women's representation in the legislature. Corporate financing may affect a candidate's popularity, if advertising engenders good will. Alternatively, corporate financing may affect which candidates choose to stand for office, and which are chosen by their parties to run. Our results, presented in the bottom row of Table 5.3, suggest that when a state restricts corporate contributions, turnout is higher, and the fraction of the lower house held by Democrats and by women is significantly higher. This gives credence to the conventional view that the composition of the groups giving money to political campaigns can affect political representation. It is clear that there is scope for expanding and refining this sort of analysis in future work. There is also the need to consider in more detail what forces are shaping the propensity to change existing campaign finance laws.

Public funding of political parties is perhaps the main alternative to relying on private contributions. The states may also provide a context for studying this, through the check-off available on some state tax returns, in which tax filers can allocate some small amount of their returns to public funding of campaigns. This phenomenon seems to have been studied only to a limited degree. Ruth Jones (1981) examines the impact of the cross-state variation in schemes for public funding of political parties during the 1970s, mainly through tax check-off schemes. She finds that around 20 percent of the population participated in the tax check-off schemes introduced. The data suggest that, in terms of financing, the Democrats are disproportionate beneficiaries. However, she does not conduct formal empirical testing of the effect of state funding on outcomes. 


\section{$5.4 \quad$ Redistricting}

Another important institutional variation across states that can have a significant impact on political (and hence policy) outcomes is the relationship between voting and political control. It is common to characterize an idealized political system as one in which the proportion of seats held is proportional to vote share. Although the normative foundations of this are unclear, it is a useful benchmark. In practice, majoritarian systems like the U.S. do not yield proportionality and, for many years, the so-called cube law was purported to characterize the relationship observed. ${ }^{29}$ The relationship between seats and votes is considered to be extremely important in the process of designing districts.

Legislative redistricting has been important in increasing the number of African-Americans who hold office, through the creation of so-called "majorityminority" districts. Tim Sass and Bobby Pittman (2000) look at the link between election structure and black representation in the South using data between 1970 and 1996. Their data are for city council elections, where they explain the fraction of blacks elected as a function of the percentage of blacks in the population and variables representing the electoral system. They estimate this in levels and first differences, finding some evidence that the move to district elections had an effect on black representation early in the sample period.

Andrea Gelman and Gary King (1994) use data on state legislative districts from 1968 to 1988 to examine whether redistricting affects electoral responsiveness - the degree to which the party composition of the legislature responds to voter preferences - and partisan bias - the fairness with which state-cumulative votes for a party translate into seats in the state legislature. $^{30}$ They find that redistricting increases electoral responsiveness, largely by inducing uncertainty in the electoral process. However, when one party controls the redistricting map, Gelman and King find that this induces partisan bias. On average, the controlling party gains 6 percent of the seats that

${ }^{29}$ See Maurice Kendall and Alan Stuart (1950). This is represented by

$$
\frac{s}{1-s}=\left(\frac{v}{1-v}\right)^{3}
$$

where $s$ is share of seats and $v$ is share of votes.

${ }^{30}$ They propose a generalization of the cube law referred to in the previous footnote where 
would have gone to the other party, had it controlled the redistricting. They conclude that "even though redistricting makes the electoral system substantially fairer overall than if there were no redistricting, the difference between Democratic and Republican control over the drawing of district maps is still one that politicians are rightfully concerned about" (page 553).

We test the extent to which a unified party influences party competition through redistricting, by analyzing the legislative composition of the 48 continental US states between 1952 and 1995. After data on the US population have been released by the Census Bureau following the decennial census, states go to work to reapportion legislative districts. In all but a handful of states (AR, HI, ID, NJ and WA), redistricting begins with the legislature and the governor. If power is divided, agreement is often difficult to reach, and redistricting can end up in the courts. We create an indicator that a party controls redistricting, using information on whether it has unified control of both houses of the legislature and the governor's office in the decennial census year. ${ }^{31}$ We then test whether the change in the number of seats held by the Democratic party in the legislature following redistricting (decennial year +2 ) is significantly correlated with whether the Democrats or Republicans controlled the state's redistricting following the census.

In Table 5.4, we regress the change in the fraction of seats held by the Democrats between all years $(t)$ and years $(t-2)$ on indicators that the Democratic party held unified control, and this Democratic control indicator interacted with an indicator that this election year is immediately after redistricting. We include analogous variables for Republican control. (Thus leaving mixed control as the omitted category.) We find evidence of the same partisan bias discussed by Gelman and King (1994). Controlling for state and year effects and time-varying state-level variables, we find that when the Democrats controlled redistricting, they protected Democratic seats in the lower house of the legislature following redistricting, and that the opposite

$$
\frac{s}{1-s}=\beta\left(\frac{v}{1-v}\right)^{\rho}
$$

where $\beta$ measures the bias and $\rho$ measures the responsiveness.

${ }^{31}$ We recognize that this will not yield a perfect measure of where redistricting is partisan, due to court challenges and legislative impasses among other reasons (see Gelman and King (1994) on this point). However, it is likely to be a useful instrument in predicting when partisan redistricting will occur. 
held when Republicans controlled redistricting. We need to be careful in our wording here: on average, if the Democrats held unified control in a state in year $t-2$, then in year $t$ the Democrats are likely to lose seats, with the opposite holding true for Democrats when Republicans hold unified control. This may be a regression to the mean phenomenon - the political pendulum swings and then swings back - but is not special to redistricting years. What is special to the post-redistricting years is that the Democrats, when in control, can stop the pendulum from swinging back as far as it otherwise would. To take an example from Table 5.4: column 3 presents results on the change in the number of seats held by the Democrats in the state lower house. If Democrats had unified control in year $t-2$, we would expect them to lose 4 to 5 seats in year $t$ on average. However, if year $t$ is just after a redistricting overseen by the Democrats, that loss is cut by 3 to 4 seats.

These results suggest that there is potential for using redistricting as a way of trying to deal with the potential endogeneity of political control. Redistricting following a census may lead to changes in legislative composition that are simply due to the redrawing of district boundaries, and not to voters' underlying preferences. This is an additional area ripe for further investigation.

\subsection{Overview}

There is little doubt that variations in institutions affecting voting, primaries, redistricting and campaign finance have significant consequences for political outcomes. Voter turnout, party representation, the degree of competition in the legislature, and the distance between the ideology of voters and their representatives are all correlated with political institutions. However, for these to have real effects on policy, it must be the case that these political outcomes are also drivers of policy. We pick up this thread in the next section, where we review what is known about the extent to which these measures of legislative outcomes influence policy choice.

As an intermediate step, we discuss whether the institutions that we have investigated in this section appear to have any reduced-form effects on policy outcomes, as in equation (9). There is some existing evidence that they do. For example, Husted and Kenny (1997) consider whether institutions had an impact on welfare spending, using data from a panel of states over the period 1950-1988. Their results are consistent with the idea that the income of the "average" voter was lowered by the extension of the franchise and that 
this led to higher welfare spending. This effect is essentially identified by the time-series variation in Southern states, where most of the restrictions obtained prior to changes in Federal law.

Racial bias in turnout has been investigated in Benjamin Radcliff and Martin Saiz (1995), who examine the impact of voter turnout over the period 1979 to 1992 on welfare spending and on policy liberalism measures (a la Wright, Erikson, McIver (1987)). They focus on welfare spending in the 26 U.S. states that have more than 5 percent black populations in 1990. Constructing measures of bias in turnout as the ratio of black to white turnout, they find, in panel data estimation that includes state fixed effects, that welfare spending is lower in states with lower black turnout. This is broadly consistent with the Husted and Kenny findings. Radcliff and Saiz also find a negative association between cross-sectional measures of policy liberalism and their measure of turnout bias. While interesting, these findings leave open the concern that turnout is endogenous.

Table 5.5 looks at the extent to which institutional rules are associated with state taxes, overall spending, and transfers. Here, we regress taxes and spending on institutional rules, together with the time-varying state level variables discussed above, controlling for state fixed effects and year effects.

We find that open primaries are associated with a reduction in total taxes and spending of roughly $\$ 20$ per capita. Open primaries also appear to have distributional effects on state spending: total transfers are significantly higher when office holders are elected under open primaries and, in particular, family assistance per capita spending is significantly higher. In contrast, the generosity of the state's workers compensation program, measured here as total workers compensation payments per capita, are negatively and significantly correlated with open primaries. Less costly voter registration - through motor-voter rules, or through day-of-polling registration is generally associated with higher taxes, higher spending and larger family assistance and workers compensation payments. Restrictions on corporate contributions are associated with lower overall taxes, but higher transfers in the form of family assistance. For all of these fiscal outcomes, our institutional rules are jointly significant.

In section 7.6, we extend this discussion to see whether there is evidence that these policy correlations are capturing the reduced-form effect of institutions on political representation. As we have already shown, these institutions are correlated with turnout and representation, providing some reason to think that these aspects of the policy process are important to underly- 
ing policy outcomes. The intermediate step in this - the effect of political representation on policy - is the subject of the next section.

\section{Political Representation and Policy Out- comes}

This section investigates the link between political representation-measured chiefly by party identity and political competition - and measurable policy outcomes. For the sake of consistency, we maintain a small core set of outcomes for the empirical work presented, focussing on total taxes per capita, total state spending per capita, family assistance spending per capita and workers compensation spending per capita.

\subsection{Party Representation}

At the heart of the democratic ideal is the notion that government policy should be guided by citizens' preferences. In representative democracies, public opinion affects policy only indirectly by influencing the identity of elected decision makers. These often represent different parties and the different ideologies of the parties are often argued to be the core choices on offer. A key issue is how opinion finds its way into the policy process, and a key role is given to elections in shaping policies that are representative of widely held opinion. This, of course, requires that people vote, the outcome of which is limited by the choices people have available to them - involving generally two candidates (one from each party) in the case of state legislatures. (As we discuss below, some states permit more direct opportunities to influence policy through citizens' initiatives.)

How parties represent preferences is a central area of research in political science. Moreover, many of the key approaches to modeling representative democracy hinge on assumptions about parties' strategies and motivations. While parties are frequently characterized as ideologically based organizations with distinct agendas, there remains an important empirical question about whether party control really does deliver measurable policy differences and whether particular policies appear to be more responsive to party identity. In light of its centrality, it is not surprising that a large literature has developed that attempts to gauge how the process of representation works 
empirically, and whether party control makes a difference in determining policy outcomes. ${ }^{32}$ Finding that parties do not matter would deal a blow to the stereotypical characterization of party differences that most commentators take for granted. There is a huge literature in political science using crosscountry and within-country evidence on whether parties matter for policy. The literature that has looked at the federal level in the United States is far from conclusive. By exploiting both cross-sectional and time-series variation, the US states are a much more promising testing ground.

In principle, it is straightforward to investigate this issue. Returning to equation (2) above, party control and party "competitiveness" can be thought of as part of the vector $\ell_{s t}$. However before estimating (2) with such variables on the right hand side, there are a number of econometric and measurement issues to be resolved.

At any point in time, the controlling parties may vary - both between the two houses of the legislature and vis a vis the governor's office - raising the interesting question of how to characterize the political complexion of the state. Policy making may well differ between unified and divided control of the legislature and the executive. James Alt and Robert Lowry (1994) consider the bargaining game that will ensue and its consequences. For the budgetary process, the governor typically has the power to propose, with the legislature having the power to amend or even throw out the budget. Although their main focus is on the federal level, the whole question of how divided government affects policy outcomes is also tackled by Alesina and Rosenthal (1995). From the point of view of voters, dividing control may provide a means of getting an outcome that is intermediate between the policy outcomes offered by either party under unified control. Once the possibility of divided government is admitted, one needs to be careful about how to measure party control in a given state, which authors have approached in a number of ways.

Beyond the questions of measurement lie the issues of endogeneity and omitted variable bias. Equation (3) represents the effect of party strategic choices (platforms and candidate choices) on election outcomes, with party choices taken as fixed. However, these are determined in equilibrium, and the empirical analysis needs to control for all factors that affect election

\footnotetext{
${ }^{32}$ It should be borne in mind that this leads to exclusion of Nebraska, since it holds nonpartisan elections and, in early years, Minnesota, since its parties were not comparable to Democratic and Republican parties in other states.
} 
outcomes and the strategic choices made by parties (such as party platforms) if those factors are themselves determinants of the policies chosen in (1). For example, a recession in a state could lead to more Democrats being elected in (3) and a larger demand for transfers in (1). Again this may render problematic the interpretation of the effect of including measures of party composition of the state houses in $\ell_{s t}$ when estimating (2).

Similarly, if parties choose platforms to suit the electorate within a state, but these campaign promises cannot be measured, then in effect the variables $\Theta_{s t}$ and $\chi_{j s t}$ enter the error term in (2). But from (3), we expect these variables to affect the composition of the legislature. Hence $\ell_{s t}$ is correlated with the error in (2), biasing inferences about the effect of parties on policy outcomes. If voters' and party members' tastes, $\Theta_{s t}$ and $\chi_{j s t}$, are largely stable over time, the inclusion of state fixed effects may be adequate to deal with this problem. Otherwise, it is important to see what happens to estimation results when parties' ideologies and/or public opinion are added as controls in (2).

One to another, papers in the literature come to very different conclusions on the significance of party control. This is perhaps not surprising, given that the studies use different estimation strategies, focus on different outcome variables over varying periods of time, and use different measures of party control while including different state specific controls. Much of the early literature finds little evidence that party control matters - see Richard Winters (1976) for a survey. Winters (1976) finds little effect of party controls (party of the governor, percentage Democrat in state lower house, and a competition index) on benefits and taxes borne by low income groups using pooled time-series cross-sectional data for 1961 and 1965. Thomas Dye (1984) runs a series of state specific time-series regressions for the period 1950-80 that examine the effect of a change in party control on state welfare spending. Allowing for divided control of the state legislatures and controlling for state income, he finds an effect of party control in fewer than half the states. Robert Plotnick and Winters (1985) look at the empirical determination of AFDC benefits using a five equation structural model that treats party control as endogenous (identified by supposing that voter preferences affect policy only through their effects on party outcomes), and also find little role for party control. James Garand (1988) considers a number of explanations for the growth of state government in the post war period, among them the idea that party control (by Democrats) is associated with faster growth of government. He runs separate time series regressions for each state during 
the period 1945-84, in which the dependent variable is the level of state government spending as a proportion of total state output, and party controls include the party of the governor, the party controlling the legislature and these two interacted. He finds little evidence for the importance of parties. Thomas Gilligan and John Matsusaka (1995) find little effect of party control (number of seats in lower and upper houses, control over legislatures and the governor's chair, competitiveness of legislative elections) on state and local general expenditures.

In contrast, recent work finds support for party control. Brian Knight (2000) finds that control of both houses by the Democrats leads to significantly higher tax rates relative to state GDP, and that control of both houses by the Republicans has the opposite effect. Colleen Grogan (1994) finds that party control (Republican control of both houses and the governor's chair) matters for Medicaid spending in random effects models, for a biannual panel of states between 1979 and 1989. Besley and Case (1995b) find that Democratic and Republican governors respond differently to term limits, with Democrats more inclined to raise taxes and spending when working under a term limit. Diane Lim Rogers and John Rogers (2000) find that Democrat control in the house is associated with larger government, measured in either revenue or expenditure terms. They also find that divided government is an important moderating device, with a Democratic governor and a Republican house leading to smaller government than a Republican Governor with a Republican house.

Divided government is also considered by Alt and Lowry (1994), who are motivated by a theoretical analysis in which states with divided governments find it more difficult to respond to a shock, with the end result being an increase in deficit finance. Using data from 1968-1987, they run a twoequation system for taxes and expenditure in separate analyses for groups of states, treating the South separately. Overall, they find deficits more likely under divided government, and greater Democrat representation associated with higher public spending. Alt and Lowry (2000) use the difference in public spending from year-to-year as their dependent variable and study the impact of duvided government for thirty-three states over the period 19521995. They find significant differences between parties in their adjustment to fiscal imbalance during their first two years in office. In cases of divided control, they find a smaller shift in the policy direction of the governor's party.

Wes Clarke (1998) considers the impact of divided government on the de- 
gree of conflict between the executive and legislature by examining the difference between gubernatorial recommendations and actual appropriations for twenty states from 1985-94 (6027 observations). A larger percentage change to the governor's recommendation is taken as evidence of greater conflict. Estimating state fixed effect models, he finds that a unified legislature and opposition governor yields greater conflict and that a greater ideological spread and party system liberalism leads to greater conflict.

We present a set of unified results on the impact of party control in Table 6.1. Here, we estimate the impact of control on a set of outcomes (taxes and expenditures), using a consistent set of controls (state income, population, and demographic variables), in a fixed effect framework for the time period 1950-1998. We find, controlling for state fixed effects and year effects and time-varying state level controls, that the higher is the fraction of seats held by Democrats in the states' lower house, all else equal, the higher are state taxes and spending per capita. On average, and all else held equal, a ten percentage point increase in the fraction of seats held by Democrats in both the lower and upper houses is associated with an increase in overall state spending per capita of $\$ 10$ in 1982 dollars. Roughly a third of that increase is attributable to higher spending on family assistance. F-tests in row 3 of Table 6.1 suggest that the fraction of Democrats in the lower and upper houses jointly significantly affect total taxes and spending per capita, and the distribution of spending in favor of family assistance.

Democratic control of both the lower and upper houses of the legislature is associated with significantly higher taxes (roughly $\$ 13$ per capita) and a redistribution of state spending in favor of family assistance: overall spending per capita does not change significantly, but spending on family assistance per capita increases by almost $\$ 4$ in 1982 dollars. This is consistent with the idea that the exact structure of political control is important and that divided control of the legislature does provide a check on policy. We find little evidence of Democratic governors spending more overall. However, Democratic governors on average increase the generosity of state workers' compensation programs, increasing spending on the program by over $\$ 2$ per capita. We also find that greater party competition in the legislature is associated with significantly lower taxes, and significantly lower spending on workers' compensation. These indicators of party control and legislative composition are jointly highly significant in our fiscal policy regressions. ( Ftests are given at the bottom of each regression column.)

One reason why we find such large and significant effects when other 
researchers do not is that our sample is much larger. Gilligan and Matsusaka use a similar methodology to that used here, but have data only at five year intervals between 1960 and 1990. Some of the research discussed above analyzed states one at a time. This limits the number of observations to fewer than 50 per state. When we analyze states one at a time, regressing total taxes per capita on state income per capita, state population, a year trend and the party control variables presented in Table 6.1, we find the party control variables jointly significant in 33 of 47 states (Nebraska is excluded). Researchers writing in the mid-1970s by necessity worked with samples half the size we have available. When we restrict our analysis to the years from 1950 to 1979, we find party control variables jointly significant in only 21 of 46 states (Nebraska and Minnesota are excluded).

\subsubsection{Controlling for Ideology and Party Heterogeneity}

Erikson, Wright and McIver (1989) argue that the failure of much of the literature to find a link between party control and policy outcomes is due to inadequately controlling for the ideological differences in party stances across states (a problem somewhat ameliorated by the inclusion of state fixed effects in many regressions). They see the link as being from liberal public opinion to liberal party elites to liberal policy. Thus, in states with more liberal electorates, both parties will be more liberal and the effect of party control is muted if public opinion is omitted when studying this relationship. In general, they find that the relationship between opinion liberalism and Democratic control is quite weak. They operationalize the study of party elite liberalism by looking at the conservatism of congressional candidates, local party chairmen, national convention delegates and state legislators. Public opinion is measured using CBS/New York Times surveys from the period 1976-82. Using a range of measures of policy liberalism in key areas, such as AFDC and Equal Rights Amendment ratification, they find a negative correlation between policy liberalism and Democratic strength in the legislature after controlling for liberalism in public opinion. While provocative, their empirical models use only small numbers of observations, and cannot include state fixed effects. ${ }^{33}$

Robert Brown (1995) disaggregates party support among different subgroups to reflect the different cleavages between the parties that dominate

\footnotetext{
${ }^{33}$ See Charles Barrilleaux (2000) for further discussion of these results.
} 
in different states. He uses polling data to show that there are distinct differences in partisan support among socio-demographic groups across states. Parties are then characterized according to their dominant party cleavage. He suggests a three-way classification of states - a southern group of states where the Democrats are predominately supported by black, low-income and rural groups, a New Deal group with Democratic support based on Catholic, low income, union and female groups, and a Post-New Deal group with Democratic support based on black, Catholic, urban, union, low income, female and Jewish groups. He then regresses welfare spending between 1976 and 1985 on party control interacted with the type of cleavage identified. However, he does not include state or fixed effects. This exercise suggests that Democratic party control does matter. However, it matters less in the PostNew Deal and Southern party cleavage states.

Wright, Erikson and McIver (1987) are among those who have considered the direct links between public opinion and policy outcomes. They find significant correlation between state opinion and state policy when using their measure of ideology based on the CBS/New York Times surveys (above) to estimate the cross-sectional relationship between ideology and state policy choices for 47 US states.

We examine the relationship between state policy and state opinion in Table 6.2, where we present regression results on the determinants of state taxes and spending, controlling for state and year effects and time-varying state-level controls. Our measure of public opinion is the Berry et al (1998) state citizens' COPE score, which has a range from 1.43 (South Carolina in 1965) to 96.99 (Massachusetts in 1988) and a median of 50.83 (Minnesota in 1980). This analysis is limited by the fact that the Berry et al measure is available only for the years from 1960 to 1993 . Nonetheless, we continue to find that Democratic party variables are significantly correlated with state taxes and spending. In addition, we find that having a liberal state citizenry, as measured using the COPE score, is significantly correlated with state taxes, state spending overall and, in particular, state spending on family assistance and workers compensation. More liberal states spend more on family assistance, and less on workers compensation. This is consistent with the idea that ideology is important - possibly for the reasons identified by Erikson, Wright, and McIver (1989).

Overall these results suggest that there is still information in the party identities even after controlling for ideology. However, it is clear that party identity and ideology measure somewhat different things in different states, 
depending on their political culture, history and policy priorities.

\subsubsection{Intensity of Party Competition}

There are good theoretical reasons to believe that a party's behavior may depend on the intensity of the challenge it faces from the other party in the state. Incentives to target particular groups depend on how easily this can swing an election, as in the theoretical models of Lindbeck and Weibull (1993) or Dixit and Londregan (1998).

Whether these effects are important in practice is an empirical matter, and US states provide an interesting context in which to study it. However, operationalizing this requires some way of measuring inter-party competition. Measures of competition tend to be functions of vote and seat shares in the upper and lower houses. Information about the share of the vote received by the governor may also be relevant, as well as whether control of the legislature is unified or divided. Thomas Holbrook and Emily van Dunk (1993) review some of the alternatives that have been used.

The most common measure of competition used in the political science literature is the Ranney index. This is generated by averaging together the proportion of seats won by Democrats in the state house and senate elections along with the Democratic percentage in the gubernatorial election, and the percentage of time that the governorship and the state legislature were controlled by the Democratic party. This is readily computed using state level data. The measure that we use here is more limited, being based only on the share of seats held by each party in the upper and lower houses of the state legislature. Other measures can be based on more disaggregated data, such as those used by Holbrook and van Dunk (1993), which rely on the percentage of the votes won by the winning candidate and the winning candidate's margin of victory in each district.

Rogers and Rogers (2000) examine whether party competition in gubernatorial races, measured as the percentage of the votes won by the current governor in the most recent election, is related to growth in the size of government. They acknowledge that there is no necessary theoretical link between government size and intensity of competition - it seems just as likely that there would be tax cuts as expenditure increases - and they do not put forward a theoretical framework to analyze this. In their study, government size is measured in both revenue and expenditure terms. Using year effects and state effects and panel data from 1950-90, they find no positive link 
between government size and political competition. The coefficient is either not significantly different from zero or negative and significant - although the latter, where found, is sensitive to the sample period chosen.

Table 6.1 presents results on the impact of competition, using a measure based on distance from 0.5 in the fraction of seats held by Democrats in the two houses. We find significant effects of party competition on total taxes per capita and for workers compensation, both of which are significantly lower, the greater is party competition. These results require more investigation. Intense competition may change the policy priorities of the elected representatives, or the policy stances that the party adopts, or the types of candidates that it fields. In addition, competition may influence legislative coalition formation and bargaining in the legislature. More research is needed to understand the mechanisms at work behind our results.

Competitiveness measures based on political outcomes are easy to compute from available data. However, they are likely to be jointly determined with the policies chosen by state governments. Suppose that a party in a particular state has little chance of being elected if it tries to follow policy platforms and candidate strategies that appeal to the party faithful (perhaps best proxied by $\chi_{s t}$ ). This may induce parties to strategically change $X_{j s t}$ and $c_{j s t}$ to please the voters, as captured by equation (3). But then the outcome based measures of competition and policies chosen are jointly determined.

Measures of competition, based either on the number of seats held by the parties or on the vote shares for candidates within districts, may be poor measures of underlying voter preferences in favor of a particular party. As discussed above, parties may change their platforms or candidates to appeal to voters. In addition, a dominant party may use redistricting to provide the party with small margins of victory in the largest number of districts possible. Measurement error in the competition variables used will bias estimates of the impact of competition on policy choice. More work is needed here; these concerns have not been addressed in the existing empirical literature, and it is hard to know whether they impose serious difficulties in practical applications. It seems likely that progress could be made if data on $\Theta_{s t}$ and $\chi_{j s t}$ could be brought into the analysis.

\subsection{Non-Party Identity of Representatives}

Legislators are characterized by more than just their party label. Of particular issue has been the extent of involvement in the political process by 
women and minorities, not just as voters, but also as legislators. For this to have a fundamental effect on political representation, it must be the case that citizens find it necessary to delegate authority to citizens of particular kinds to further their policy ends.

In principle, the effects of legislature identity on policy outcomes can be studied by including this information in $\ell_{s t}$ when studying the impact of composition on outcomes. In theoretical terms a process of legislative bargaining in which policy preferences of representatives matter would suggest that policy stances of representatives should matter (see, for example, Daniel Diermeier and Antonio Merlo (2000)). However, the literature investigating these issues in cross-state data is quite thin.

The presence of women in state legislatures appears to have had a significant effect on state policy. The Center for the American Woman and Politics finds that women on average give higher priority to policies related to children, families and health care. Sue Thomas (1994), in a study of 12 state legislatures, finds that women spend more time and effort on bills related to family issues. Case (1998), using US state panel data from 1978-91, documents the extent to which a state's child support enforcement policies tightened as the number of women legislators in the state grew. Controlling for state fixed effects and year effects, and time-varying state-level economic variables, Case finds that the number of women legislators is significantly correlated with the passage of several child support laws. Besley and Case (2000), using state panel data from 1975-88, find that the fraction of women in state upper and lower houses are highly significant predictors of state workers compensation policy.

We examine whether women in state legislatures have a significant effect on policy making in Table 6.3. We focus on a number of policy variables that researchers have posited are sensitive to the gender composition of the legislature (Thomas 1994), in particular on family assistance per capita, and policies related to child support enforcement - here, withholding of child support immediately after the non-resident parent becomes delinquent in payments, and the ability to establish paternity to the child's 18th birthday. We find, controlling for state and year effects and time-varying state-level controls, with or without controls for the ideology of state citizenry, that women in the legislature apply pressure to increase family assistance, and to strengthen child support laws. These results add to the growing evidence that the identity of representatives affects policy choice.

Given the fairly rich biographical information now becoming available on 
elected representatives, there is scope for further work that looks at how characteristics of legislators affect policies. We anticipate growth in this area of research in the future.

\section{$7 \quad$ Policy and Institutions}

In this section we look at the effect of political institutions on policy outcomes directly. For the most part, we interpret these as the direct policy consequences of an institution - for example, when possession of the line item veto increases the bargaining power of the state Governor. However, there may also be important indirect effects - as when institutions change the ideology, composition and/or control of the state legislature along the lines discussed in the previous section. This latter possibility, and its implications, are discussed in section 7.6.

\subsection{Direct Democracy}

At the present time, twenty-three US states have a provision for some form of direct democracy, typically through an initiative process whereby citizens can place ballot propositions, which are voted on subsequently. There is now widespread interest in this type of institution and its effects on the policy process. ${ }^{34}$

Our partition of institutions in section 3 allowed for initiatives to appear both as part of $I_{1 s t}$ in equation (1) and in $I_{2 s t}$ in equation (3). The first of these is motivated by the model of Gerber (1996), which considered how, given a set of policy preferences in a legislature, the availability of the initiative could lead to a change in the equilibrium policy. Moreover, the legislature may make such a change pre-emptively, if legislators anticipate the possibility of an initiative at some later date. Hence, the possibility of initiatives forces greater agreement between voter preferences and policy outcomes, assuming that representatives elected to the legislature have views that are out of step with the citizens as large.

Similar conclusions follow from the theoretical analysis of Besley and Coate $(2000 \mathrm{~b})$ but for quite different reasons. They develop a model in which initiatives affect electoral outcomes. This also motivates why the availability

\footnotetext{
${ }^{34}$ See David Magleby (1984) and Shawn Bowler, Todd Donavan and Caroline Tolbert (1998) for background discussion.
} 
of citizens' initiatives appears in equation (3). They argue initiatives have an impact via issue unbundling. In general elections, many issues are decided at once, which may result in issues that are not electorally salient being distorted away from what a majority desire. ${ }^{35}$ Initiatives allow such issues to be unbundled from the rest as voters can have a direct say on them. Besley and Coate show that this can change the probability distribution of a range of policy outcomes and the composition of candidates who are chosen to run.

Both of these theoretical approaches, as well as many popular discussions of initiatives, imply that citizens' initiatives are a device for bringing policy into line with public opinion. ${ }^{36}$ Gerber (1996) and Besley and Coate (2000b) both argue that the effect of an initiative can be felt even if an initiative is not actually called. For empirical purposes, this suggests that the actual conduct of initiatives in states that have them need not be a very good indicator of their influence. Hence, it does make sense to study the availability, rather than use, of the initiative when looking for its policy impact. ${ }^{37}$

One strand of empirical literature on initiatives has used data from US states to test whether public opinion and policy outcomes are closer together in initiative states. For example, drawing on the work of Wright, Erikson and McIver (1987), Edward Lascher, Michael Hagen and Steve Rochlin (1996) and John Camobreco (1998) investigate whether the link between aggregate measures of policy outcomes and public opinion is closer when states allow

\footnotetext{
${ }^{35} \mathrm{~A}$ large body of empirical evidence from political science supports the lack of congruence of policy and voter preferences on a variety of issues - see Besley and Coate (2000b) for references.

${ }^{36}$ This is is not universally believed. Some are concerned that voters are easily influenced by slick advertising campaigns, in which case the initiative process in the United States may actually enhance the power of special interests (see, for example, David Broder (2000)). From a welfare point of view, there is also the concern that initiatives will lead to minorities being unfairly targeted and with citizens being forced to choose on issues on which they are ill-informed.

${ }^{37}$ There are a number of other theoretical contributions on initiatives. These include Matsusaka (1992), which discusses what kinds of issues will be decided by initiative (as opposed to elected representatives). He argues that controversial issues that are not too technical, such as banning bilingual education, will tend to be tackled via initiative-largely to allow legislators to avoid making decisions on controversial issues. Technical issues are often too complicated to be settled via initiative. Arthur Denzau, Robert Mackay and Caroly Weaver (1981) make a similar point concerning the ability of initiatives to constrain agenda setting politicians with non-majoritarian preferences. Matsusaka and McCarty (1999) emphasize the possibility that holding an initiative can reveal information to legislators about policy preferences.
} 
citizens' initiatives. They find no significant effect. ${ }^{38}$

With respect to specific policy issues, Gerber (1999) finds that policy outcomes on the death penalty and abortion regulation are closer to public opinion in states that permit citizens' initiatives, even though these policies are not directly determined via initiatives. Gerber uses cross-sectional state variation from the 1990s and compares stances on an array of policies. She finds significant differences (at the 10 percent level) for personal income taxes (initiative states lower); highway, natural resources and hospital spending (initiative states higher in all cases); and the implementation of "three strikes" legislation (initiative states lower). Gerber looks in greater detail at the death penalty and parental consent laws for abortion, using public opinion data to estimate median voter preferences. With cross-sectional data for 1990, she runs a logistic regression that interacts whether a state has an initiative with public opinion, and finds that states with initiatives mirror public opinion more closely.

Other studies have focused more on whether initiatives are devices for reducing the size of government. There is a widespread belief that agency problems lead to government that is too large, and that government can be reigned in by initiatives. This is the essence of the theoretical approach of Denzau, Mackay and Weaver (1981).

In this spirit, Jeffrey Zax (1989) investigates how access to initiatives affects state expenditures per capita, in a cross-section of fifty states for 1980. Contrary to the idea that initiatives promote smaller government, he finds that state spending is significantly higher in states that permit direct statutory initiatives. Paul Farnham (1990) estimates the cross-sectional effect of citizens' initiatives and referenda using data on 735 communities, taking the log of community expenditures as the dependent variable, finding little or no evidence that access to the initiative is important.

Matsusaka (1995) is the most thorough cross-sectional study of the effect of initiatives on cross-state taxing and spending. He regresses government expenditures and revenues in 49 states (Alaska is excluded) on a number of control variables for a panel of states sampled over a 30 year period at five year intervals from 1960 to 1990. He includes year effects, but not state fixed effects, since the presence of initiatives is largely fixed within states over time. His main finding is a strong negative effect on expenditures of access to the initiative. He also finds some evidence that the effect is

\footnotetext{
${ }^{38}$ Matsusaka (2000) provides a persuasive critique of their methodology.
} 
strongest where the signature requirement on expenditures is low. This is in tune with the idea that initiatives may have a role to play in reducing agency problems that result in the state being too large. However, the cross-sectional nature of the identification strategy raises the issue of whether some other state characteristic, correlated with initiatives, is driving the results. Dale Bails and Margie Tieslau (2000) present somewhat similar results running a random effects panel data regression of total expenditures on initiatives for the period 1969-94. They also find a negative and significant effect of a state permitting an initiative. ${ }^{39}$

This variety of findings makes it interesting to take a fresh look at the issue. We present results on the impact of citizen initiatives on state spending and revenues in Table 7.1. We regress state total taxes, state income taxes, total government spending, and spending on family assistance programs on an indicator that the state allows citizen initiatives, with controls for year effects and for state income per capita and income squared, state population and population squared, the proportion of state residents aged 65 and older, and the proportion aged 5 to 17. Like Matsusaka (1995), we do not control for state fixed effects, because only four states (FL, IL, MS, and WY) changed their policy on initiatives during the 38 year period from 1960 to 1997 . In Table 7.1 we present three estimates of the impact of initiatives on state fiscal outcomes. In the first panel, we estimate OLS regressions with robust standard errors, allowing for an unspecified pattern of correlation between the unobservables from the same state over this period. The estimation procedure constructs a 38-by-38 variance-covariance matrix for each state, which may lead to a lack of precision in the standard error estimates. Using this estimation procedure, we find no significant effect of citizens' initiatives on state revenues or state spending. In the second panel, we estimate the impact of initiatives using a random effects specification. Here the estimates suggest that state tax revenues per capita - and income tax revenues in particular - are significantly lower in states that have citizens' initiatives. When we use a between-state estimator in panel three, in which regressions are run on state means, the between-state estimates, like the robust estimates in panel one, suggest that the standard errors are large - and too large to say conclusively that state initiatives have held down state taxes and spending. Note that if nothing changed within the state from year

\footnotetext{
${ }^{39}$ In related evidence, Werner Pommerehne (1990) shows that Swiss cantons that use the initiative have smaller state governments.
} 
to year, and we estimated OLS regressions using 38 years' worth of data from each state, the standard errors would fall by a factor of $6: \sqrt{38}=6.16$. Estimating the effect of state initiatives using only the state means ignores information that can make our estimates more precise, and is therefore less than ideal. However, the fact that the observations from a given state each replicates roughly the same information every year makes it difficult to interpret these findings. In no specification presented in Table 7.1 are initiatives significantly correlated with total government spending per capita, or with family assistance spending.

Using a random effects specification, we find a negative correlation between initiatives and taxes. However, results presented in Table 7.1 illustrate the great difficulties in providing reliable estimates when institutions vary only across states, and not within states over time. Panel data are only of limited value in this context.

\subsection{Electoral Accountability}

An important issue is how voters hold politicians to account for their performance while in office. Folk wisdom suggests that deterioration in economic performance and tax increases, in particular, are not conducive to electoral success. This claim was made forcefully by Sam Peltzman (1992) in his assessment of gubernatorial electoral chances. ${ }^{40}$

In section 3.1.3 above, we discussed how empirical models of elections can incorporate this possibility, through the addition of history $H_{s t}$ into estimating equations. From a theoretical point of view, these claims are best justified in political agency models where there is private information about an incumbent's type (representing his competence or his willingness to consume rents at the citizens' expense) or else there is uncertainty about the true state of public finances. Models along these lines were first developed by Barro (1973) and Ferejohn (1986). It is straightforward to see how they can generate an aversion to tax increases, if the latter are correlated with greater incompetence or greater likelihood of rent-seeking behavior.

A key feature of these models is that voters will condition their voting decision on incumbent behavior, either to curb moral hazard problems or else to sort in politicians with desirable characteristics. Hence, we would expect to

\footnotetext{
${ }^{40}$ There is a long-standing tradition of studying the determinants of retrospective voting in U.S. national elections. See, for example, Morris Fiorina (1981).
} 
see voters punish indicators of poor effort, and reward the opposite. Electoral accountability is in large measure about reputation formation, which can be built around the historical record of parties and governors. Besley and Case (1995b) argue that whether governors are working under term limits provides a test of agency models, as the governors' time horizons vary exogenously with term limits. We discuss their results in greater detail below.

Relative performance may also be an important determinant of electoral success. Besley and Case (1995a) develop a model in which voters use crossstate comparisons of policy outcomes to evaluate office holders, which in turn generates yardstick competition between incumbents. In a world where neighboring jurisdictions face correlated shocks, information about one's own state can be gleaned through observation of the policy decisions taken by another. In such a world voters would be rational to use relative performance comparisons. This will, in turn, make tax setting decisions across neighboring states interdependent. In terms of electoral accountability, we should expect to see incumbent success correlated with neighboring states' policies and economic conditions, as well as one's own. ${ }^{41}$

The idea that voters respond to changes in the economy is widely documented in a variety of empirical contexts - see Peter Nannestad and Martin Paldam [1994] for a review of the literature. For the US states, this means linking voting outcomes to general indicators of state-level economic health. John Chubb (1988) considers the determinants of state elections as a function of the performance of the state economy and other factors using data from 1940-82. He finds very little evidence that changes in state income levels affect election outcomes. These results are consistent with the findings of James Adams and Kenny (1989) and Peltzman (1987) who both show that whether a government is reelected is not correlated with economic growth in the state in question. However, voters may not view state income per capita as being strongly affected by unobservable incumbent effort or type. This line of reasoning ties into the large literature on political budget cycles where the most persuasive theoretical contributions, such as Kenneth Rogoff (1990), use electoral accountability based on incomplete information as the foundation. Cross-country evidence such as that developed in Alesina and

\footnotetext{
${ }^{41}$ This idea can be used to underpin observation that states appear to make interdependent fiscal decisions in a variety of contexts as suggested by Case, James Hines and Harvey Rosen (1993). Jack Walker (1969) applied this idea to the diffusion of policy innovation across states - see also Frances Stokes Berry and Berry (1992) and Koleman Strumpf [2000].
} 
Nouriel Roubini (1992) finds only limited evidence in support of the existence of such cycles.

Table 7.2 looks at this in the context of the US states, where we focus exclusively on the states that have a four year electoral cycle for the sake of easy comparison. The data do not show any marked political business cycle in either state income or unemployment. This is consistent with Chubb's observation that these are not key indicators for which incumbents are held accountable at the state level. Arguably, the openness of the US states makes it very difficult for individual state governments to have much impact on state level unemployment. Seen in this light, the insignificant effects observed are not surprising.

A more promising approach is to look for evidence of electoral accountability as a function of policy variables. In principle, tests for whether electoral success depends on past policy choices are straightforward. As discussed in section 3.1.3 above, for governors, electoral success can be represented as a discrete variable measuring whether the governor is reelected, as in Besley and Case (1995a), or as the percentage of the vote going to the dominant party, as in Lowry, Alt and Karen Ferree (1998). The latter also contend that the ruling party will be held to greater account when there is unified rather than divided control of state offices. Furthermore, accountability should be more pronounced in gubernatorial elections, where a single agent can be blamed, rather than in legislative elections where blame is harder to attribute.

Lowry, Alt and Ferree find that there are fewer votes for incumbents who experience a shock when there is unified rather than divided government, and that the effect is larger in gubernatorial elections. In their study, voters also respond to the difference between state income growth and national income growth. Susan Kone and Winters (1993), in pooled time series and cross-sectional regressions from 1957-85 that do not include year or state fixed effects, find that Democratic governors are punished for putting up taxes. Besley and Case (1995a), in a model that includes year and state fixed effects, find that a governor is more likely to be defeated if he puts up taxes, but is more likely to win if his geographic neighbors do.

Richard Niemi, Harold Stanley and Ronald Vogel (1995) also test for the importance of tax increases on gubernatorial elections using individual data from exit polls for 34 states in 1986. They model the probability that a respondent voted Republican in a particular state as a function of respondent, state and national variables. They allow the effect of the state-level economic 
and policy variables to vary according to whether the incumbent governor was a Democrat or a Republican. Consistent with the results of Besley and Case (1995a), they find that support for the incumbent party falls when taxes are increased, and that state level income appears to be an important determinant of voting decisions.

Justin Wolfers (2001) also considers the nature of gubernatorial electoral accountability in US states. He shows that events beyond the control of a governor (specifically oil prices) appear to be correlated with whether or not the governor is reelected. He interprets this as irrational behavior by voters. ${ }^{42}$

Overall, these results leave little doubt that the electoral process does hold policy makers to account for the policies chosen during their tenure. This cements the link between economic and political outcomes in a way that is consistent with theories based on political agency. The literature has not, however, looked in much detail at how institutions affect the process by which voters hold politicians to account. An exception is the work by Stratmann and Aparicio-Castillo (2001) who show that incumbent defeat in house elections is more likely when campaign restrictions are in place.

\subsection{The Scope of Elective Office}

While every US state has an elected legislature (in almost all cases two) and a directly elected chief executive, there are marked differences in the extent to which other kinds of state officers are directly elected. Good examples of institutional variation are public utility commissioners, who are elected in eleven states, high court judges, who are elected in twenty-three states, and insurance commissioners, who are elected in twelve states. In states that appoint officer holders, it is typically the state's governor who is key (although confirmation may sometimes be required in the legislature).

In terms of the theoretical structure laid out in section 3, institutions affecting which positions are elected or appointed may be considered part of either $I_{1 s t}$ or $I_{2 s t}$. Having a more independent judiciary (if indeed this is achieved by appointment of judges) could, for example, affect judicial oversight of legislation, and hence constrain policy making in a legislature. In that case, such rules would enter as part of $I_{1 s t}$. If $\ell_{s t}$ is expanded to

\footnotetext{
${ }^{42}$ However, if the management skills of a governor are more in evidence when there are good times rather than bad, then this would be consistent with rational updating on the part of voters.
} 
include the characteristics of a range of state office-holders, such as judges and regulators, then we might expect the pattern of selection to enter as part of $I_{2 s t}$ in (3).

The latter possibility can be motivated by the theoretical approach of Besley and Coate (2000a). They argue that direct election of office holders is a force for increasing the salience of that dimension of policy. In the context of regulators, we should typically expect this to move policy in a proconsumer direction. General elections in which regulatory issues are bundled with other "bigger" policy issues enhance the power of special interests, party elites and single issue voters. Similar arguments would also apply to the election of the judiciary.

If there is a move towards pro-consumer policies, then this may have important dynamic implications. For example, in electricity, network investments have long lives and may benefit from long-run regulatory commitments which may be harder to achieve if regulators favor consumer interests. Similarly, judges may reach more short term popular judgements if they face reelection. ${ }^{43}$ To some degree, such incentive problems can be mitigated by having longer terms in office. However, there is a possible trade-off between the degree of accountability and the ability to commit.

Whether elected regulators behave differently from those that are appointed has been widely studied in the empirical literature. A number of studies, including Berry (1979), Kenneth Costello (1984), Mark Crain and McCormick (1984), Peter Harris and Malcolm Navarro (1983), Navarro (1982), and Walter Primeaux and Patrick Mann (1986), have looked at the evidence from different perspectives. ${ }^{44}$ Some of these contributions have looked at rate setting, while others have looked at broader indicators of the state's regulatory climate. Costello (1984) reviews the evidence, and concludes that the appointment or election of public utility commissioners makes little difference to the average rate payer. However, the data and time periods used differ across studies, as do the set of controls and institutional measures. More worrisome for convincing empirical testing is the fact that the literature is predominantly cross-sectional, with particular researchers

\footnotetext{
${ }^{43}$ See Eric Maskin and Jean Tirole (2001) for an insightful model of the pros and cons of judicial independence. In their model, elected policy makes may be inclined to "pander" to voters - do what is popular rather than what they know to be right.

${ }^{44}$ The large empirical literature on the effects of regulation in US states begins with the seminal contribution of George Stigler and Anne Friedland (1962), and is expertly reviewed in Paul Joskow and Nancy Rose (1989).
} 
choosing selected years and available controls to report their findings.

The more recent literature seems to be more encouraging to the view that electing regulators makes a different. John Formby, Banamber Mishra and Paul Thistle (1995) using data from 1979-1983 on a selection of investorowned utilities and find that election of public utility commissioners has a negative effect on bond ratings, consistent with a squeeze on margins due to more pro-consumer choices. Joseph Fields, Linda Klein and James Sfiridis (1997) also find that elected commissioners from the insurance industry are more pro-consumer - the market value of life insurance companies doing business in California declined sharply following the passage of Proposition 103 which changed the method of selection of the insurance commissioner from appointment to election. Using data from 1985, Susan Smart (1994) reports that telephone rates are lower in states that elect their public utility commissioners.

Besley and Coate (2000a) exploit panel data to look at electricity regulation. They find a robust negative correlation between electing regulators and the price tariff faced by consumers. However, this begs the question of whether the decision to elect or appoint regulators is simply correlated with important unobservable differences between states. They suggest a test, motivated by theory, that prices should respond less to cost shocks when states elect their regulators, if this results in more pro-consumer regulation. They test this prediction using data on electricity prices from a panel of US states and find strong support for the idea that direct elections produce more proconsumer regulators. One important feature of this test is that, even though the institution may be relatively fixed over time, the comparative static refers to a variable that varies over states and time (the shock to the cost of producing electricity). ${ }^{45}$ Hence, the prediction can be tested even with the inclusion of state fixed effects.

There is a significant body of work on the difference between elected and appointed judges. In line with the theoretical discussion above, there is evidence that appointed judges are more independent than elected judges. As we discuss further below, Henning Bohn and Robert Inman (1996) find that whether a constitutional restriction on deficit finance is effective depends on whether the court that has to enforce the restriction is elected or appointed. Restrictions with appointed courts do not appear effective in their data. Andrew Hanssen (2000) tests the idea that election leads to

\footnotetext{
${ }^{45}$ Cross-secitonal variation comes from the differing production structures across states.
} 
greater judicial independence by looking at staffing levels in three budgetary agencies that are subject to judicial review: public utility commissions, insurance commissions and education bureaucracies. He argues that the kind of defensive activity that more independent judiciaries engage in will result in them having more staff. Using cross-sectional data for 1983, he shows that states with elected judges have significantly smaller bureaucracies controlling for a number of other observables. Hanssen (1999) looks at whether states that elect their judges have more or less litigation activity, arguing that this may reflect the degree of uncertainty in the operation of courts. Using data from all 50 states, he tests whether there are significantly more public utility disputes (1978-83), and High Court and Trial Court Filings (1985-94) in states that elect their judges. The main finding, identified from cross-sectional differences, after controlling for a number of economic and demographic variables, is that appointing states have significantly higher rates of judicial activity in public utility disputes and High Court Filings, but not in Trial Court Filings. ${ }^{46}$

\subsection{Term Limits}

US states also vary in whether they hold elected officials to term limits. Some kind of term limit is observed for governors in roughly half of the states, and a key issue is whether we should expect such limits to affect policy outcomes. Besley and Case (1995b) consider a framework in which term limits change the incentives of politicians to build a reputation. They base this on an agency model with imperfect information. When a term limit binds, there may be a temptation to play the end game, resulting in significant changes in policy.

One way to examine term limits is cross-sectionally, looking at the permanent differences in policies in those states that have such limits. This is the approach in early work on the topic by Crain and Robert Tollison (1977, 1993), and Crain and Lisa Oakley (1995). Crain and Tollison (1977) make the interesting and important point that if political office is a productive asset, one used to produce political outcomes, then candidates for the office should be willing to pay more for the opportunity to serve in states with longer terms, and in states without term limits. They find, using cross-sectional

\footnotetext{
${ }^{46}$ There are also more public utility commission rulings in states that appoint their utility commissioners.
} 
data for races run in 1970, that challengers spend less money when running for two two-year terms than do those running for one four-year term. In addition, challengers spend less in states with term limits. Crain and Oakley examine whether states that allow governors to succeed themselves indefinitely have different public capital stocks and flows than do states where governors are restricted by some sort of term limit. They find, using data from the 1980s, and controlling for a number of state institutions, that the stock of state government capital per capita, the change in the stock, and the percentage change in the stock, are all lower in states with term limits. Bails and Tieslau (2000) argue that term limits should lower the rate of growth of spending, by making policy makers more responsive to citizens' preferences. They test for this using a random effects model for the period 1969-94, and confirm a negative coefficient on state expenditures. All of these results raise the usual issue of whether such limits are merely proxying for omitted state level characteristics. State income per capita and state population are significantly lower in states with term limits, to name but two important differences between states with and without term limits (Besley and Case 1995b, Table III, p. 778).

A second strand of the term limits literature uses data on the behavior of representatives in the US Congress to predict how state representatives facing term limits would be expected to behave. Lott and Stephen Bronars (1993) analyze Congressional voting data from 1975-90, and find no significant change in voting patterns in a representative's last term in office. However, it is far from clear that Congressional representatives who announce they are stepping aside provide an adequate picture of the behavior of state governors who are bound by law not to run again for reelection. A provocative paper on potential end-games in the U.S. Congress is provided by John McArthur and Steven Marks (1988), who observe Congressional behavior in a lame duck session of Congress: in post-election sessions, members who have not been reelected are at times called upon to vote on legislation before the swearing in of the new Congress. McArthur and Marks observe that lame duck representatives were significantly more likely in 1982 to vote against automobile domestic content legislation than were members who were returning.

Besley and Case (1995b) identify the effect of a term limit from the difference between first and second terms in office for incumbents who face term limits. Controlling for state fixed effects and year effects, and using annual data from the 48 continental US states from 1950-86, they find that a variety 
of policy measures are affected by term limits. Specifically, state taxes and spending are higher in the second term when term limits bind in states that have them. Such limits tend to induce a fiscal cycle with states having lower taxes and spending in the first gubernatorial term compared to the second.

John List and Daniel Sturm (2001) apply a similar methodology to crossstate variation in environmental policy. Using data for the period 1960-1999, they find that governors in their last term in office are significantly more likely to spend resources on environmental protection. However, this term limit effect is muted in states where a larger fraction of citizens belong to environmental organizations. They also show that their term limit effect varies according to the margin of victory in the gubernatorial race - with term limit effects being attenuated when the margin of victory is larger.

We update the results from Besley and Case (1995b) using data from 1950-1997, and present the results in Table 7.3. Controlling for state and year effects and time-varying state-level variables, we continue to find that in those years in which an incumbent governor cannot stand for reelection because of a term limit, on average state spending per capita is significantly higher (roughly $\$ 15$ per person higher in 1982 dollars). However, our earlier finding that taxes are higher when the governor is a lame duck does not hold in this longer panel. Total taxes per capita are lower, although not significantly so, on average in those states in which the current governor cannot stand for reelection.

We examine this further in Figure 3, in which we graph the pattern on the effect of having a lame duck, year by year, from 1950 to 1997, controlling for the same time-varying variables used in the regressions presented in Table 7.3. We find that, over time, the impact of having an incumbent who cannot stand for reelection has changed from being on average positive and significant, in the first half of the period, to being on average negative and significant (and much more variable year-to-year) in the second half. We can offer no simple explanation for this pattern. It continues to emerge when we control for other time-varying state level variables that we think may influence taxes — such as the need for a super majority to change taxes, the fraction Democrats in the lower house of the legislature, the amount of competition between the parties in the legislature, whether Democrats control both houses of the legislature, and the level of grants from the federal government. We parameterize the changing pattern in the impact of having a lame duck governor in regression results presented in the 2 nd and 4 th columns of Table 7.3. We see that, for both taxes and state spending, governors in the 
first half of our time period spent and taxed more when they could not stand for reelection but that, over time, this phenomenon has changed. It seems likely that some omitted variable is responsible for the change in behavior observed for governors working under a term limit. This is an area ripe for future research.

The literature to date mostly treats term limits as exogenous. However, there have been some changes in such limits over time. The major trend in in the second half of the twentieth century was the abandonment of one-term limits, which survive today only in Virginia. ${ }^{47}$ An interesting unanswered question is whether this can be rationalized as a welfare improving change for voters, given the incentive effects of term limits that have been uncovered.

\subsection{Budgetary Institutions}

Central to much of the public choice literature is the idea that a fiscal constitution should limit the policy choices of elected representatives - see, for example, Brennan and Buchanan (1985). In this section we study a variety of budgetary institutions that affect budgetary procedures, mostly in the direction of greater fiscal conservatism. Stricter budgetary institutions are generally motivated by the notion that governments tend to be too large relative to voters' wishes. This view can be motivated either by the Leviathan model of Brennan and Buchanan (1980) or a more sophisticated agency view as in Barro (1973) and Ferejohn (1986). Daphne Kenyon and Karen Baker (1984) characterize the proliferation of such measures as part of a broader "Tax Revolt" in the 1970s, with Califronia's Proposition 13 leading the way. It is interesting to note that a number of the restrictive budgetary institutions that are now observed were imposed by citizens' initiatives, fuelling the notion of a popular rebellion against government profligacy.

In terms of the theoretical structure of section 3 , budgetary institutions are best thought of as belonging to the vector $I_{1 s t}$ in equation (1). However, they would belong to $I_{2 s t}$ if they changed the kinds of representatives who were elected. The six main institutional categories that we discuss here are:

- Tax and expenditure limitations.

\footnotetext{
47 Adams and Kenny (1986) consider the optimal role of term limits and correlate the presence of term limits with the length of term in office. On the whole, term limits are more prevalent where term lengths are longer.
} 
- These fall into three broad categories: (i) indexed limits on the growth of revenues or expenditures, for example, to the population growth rate; (ii) requirements that voters approve all new taxes; and (iii) supermajority requirements that require anywhere between three-fifths and three-quarters of the legislature to approve tax increases. There are twenty-four states with indexed limits, thirteen allow an override with a supermajority vote, and five require a simple majority if the governor has declared a state of emergency. Kim Rueben (1997) gives a useful overview of the history and content limitations in category (i) above. Half the states with such limitations restrict the growth in state expenditures to the growth rate in personal income averaged over some previous period. Five others restrict the size of appropriations to a specified percentage of state income, while four others restrict growth to an index of population growth and inflation. Three other states restrict the absolute expenditure growth rate. Spending on capital projects is excluded, as are federally funded projects. Half of the limits in place are constitutional, with the remainder being statutory. Most tax and expenditure limitations were introduced in the 1970s, which many believe reflected a general disillusionment with government and a view that spending was out of tune with what a majority of voters preferred. ${ }^{48}$

- Balanced budget requirements and limited carry-over provision.

- The Reagan era of budget deficits ushered in a period of heightened concern about the causes and consequences of budget deficits. This filtered into state politics too, with many states passing measures restricting the ability of elected officials to use deficit finance. Indeed, all states, with the exception of Vermont, have some measure of this form. There are, however, differences in the way in which the laws are structured (see James Poterba (1997)). The weakest form of restriction requires that the Governor submit a balanced budget (forty-four states). This need not lead to balanced budgets being passed by the legislature (thirty-seven states have a rule requiring this). Stricter still is a prohibition on carry-

\footnotetext{
${ }^{48}$ See Helen Ladd and Nicolaus Tideman (1981) for background discussion.
} 
ing forward a deficit, which has been passed by twenty-four states. (See also Bohn and Inman (1996), Table 2.)

- Restrictions on issuing state debt.

- Restrictions on raising public debt come in four main categories (see Roderick Kiewert and Kristin Szakaly (1996), Table 1). At one extreme are outright prohibitions on guaranteed long-term debt. Even if there is no prohibition, some states require referendum approval. The weakest restrictions are revenue-based limitations or some kind of supermajority voting requirement in the legislature.

- Line-item veto for the state governor.

- This allows the state governor to strike out a particular unwanted budgetary item rather than vetoing the budget as a whole. This should, in theory, enhance the bargaining power of a governor in the budgetary process. We expect this to be most important when the preferences of the legislature and the governor diverge.

- Budgetary Transparency

- States budgetary procedures differ on a number of dimensions including the extent to which they run their budget accounting on a single year or multi-year basis, whether they use generally accepted accounting standards, and whether they use publicly available performance measures. Alt, David Dreyer Lassen and David Skilling (2001) construct an index for the US state based on a variety of indicators from the National Association of State Budget Officers and the National Conference of State Legislatures. This is intended to capture the overall transparency in a state's budgetary process.

- Budgetary Cohesion

- States vary in the extent to which the budgetary process is fragmented across a variety of committees Roughly half the states divide spending responsibility over a number of committees rather 
than having a centralized appropriations committee. There is also variation in the extent to which states have separate taxing and spending committees.

The effectiveness of budgetary institutions in restraining government is moot. Some regulations are difficult to cnforce, and government agents are thought to be resourceful in crafting ways around others. Poterba (1997) points to how the nominal timing of tax changes can be altered to comply with many rules. There are also issues about the willingness of external agencies to enforce them.

The early literature on tax and expenditure limitations fueled such skepticism by finding only weak responses to their introduction. For example Burton Abrams and William Dougan (1986) could find no effect of the lineitem veto or borrowing limits, but did find a marginally significant negative effect of tax and expenditure limitations. However, because their results rely solely on cross-sectional variation, it is not clear how much weight we should place on them, for the reasons we have already outlined. Bails and Tieslau (2000) run random effect models of state spending with both supermajority requirements and expenditure limits on the right hand side, for the period 1969-1994, and find a negative and significant effect of expenditure limits and supermajority requirements. ${ }^{49}$ In contrast, Rueben (1997) finds that binding state tax and expenditure limits have no effect in either OLS cross-sectional or fixed effects specifications. Ronald Shadbegian (1996) considers the effect of tax and expenditure limitations on the growth of government expenditures in a panel of states over the period 1972-87, allowing tax and expenditure limitations to have both a level effect and an interaction effect with state income. Consonant with Rueben (1997), he finds no level effect. However, the interaction effect is always significant. This is intriguing, although there is no obvious interpretation of this result from a theoretical point of view. Supermajority requirements in the legislature are studied in Brian Knight (2000). He finds that supermajoirity requirements reduce taxes as a proportion of state income by between $1.7 \%$ and $3.6 \%$ in various specifications.

Rueben (1997) and Knight (2000) both take seriously the idea that tax and expenditure limitations and/or super-majority requirements are determined endogenously. Many are fairly recent, and it seems unlikely that

\footnotetext{
${ }^{49}$ In fact the latter is interacted with balanced budget amendments which makes it difficult to assess whether the supermajority requirements is significant when it is entered alone. However, results below suggest that it probably does.
} 
their introduction is exogenous to the history of fiscal policy in the state in question. Both authors suggest that the availability of direct legislation as an instrument for the budgetary institution, and estimate two-stage least squares models that use this. Given that citizens' initiatives have often been used to constrain taxing and spending power, this is a promising avenue. Rueben (1997) finds tax revenues as a percentage of personal income are approximately $2 \%$ lower in states with tax and expenditure limits in her two stage least squares specification. This contrasts with her ordinary least squares estimates in which she finds no significant effect. However, because she is using a fixed institution as an instrument, she is unable to employ state fixed effects in the two stage least squares case. In addition to direct legislation, Knight (2000) uses the legislative vote required to pass a constitutional amendment and the sessions required to consider an amendment as instruments. He finds that permitting direct legislation is positively correlated with having supermajority requirements and that having a larger number of sessions is negatively correlated with it. His two stage least squares analysis continues to find a negative effect of super-majority requirements on taxes. As well as being a useful robustness check, both Rueben (1997) and Knight (2000) help to isolate the mechanism behind Matsusaka (1995)'s finding that there is a negative correlation between public spending and the availability of direct legislation.

Poterba (1994a) also finds that budgetary institutions are important. Using state-level data from the National Association of State Budget Officers for the period 1988-92, he finds that no-deficit carryover rules and tax and expenditure limitations affect the short-run patterns of taxes and spending in response to shocks (calculated as differences between actual and budgeted outcomes). ${ }^{50}$

Poterba (1997) looks in detail at rules that restrict the ability of states to run budget deficits. He points out that there are good reasons, a priori, to be suspicious of the efficacy of budget rules. This is due to the relative ease with which accounting procedures can be modified and the nominal timing of taxes and expenditures can be changed. Moreover, in many states they apply only to part of the government budget (the "general fund" budget). Poterba's review of the existing literature leads him to conclude that fiscal institutions do matter, but that studies to date provide little guidance on

\footnotetext{
${ }^{50}$ Poterba also provides evidence that divided state governments respond more slowly to unexpected deficits.
} 
whether stricter anti-deficit rules will reduce spending or taxes.

Bohn and Inman (1996) examine the effect of budgetary rules on deficits using panel data for 47 states over the period 1970-1991. They model general fund surplus as a function of economic and political control variables and the state's budgetary institutions, using fixed and random effects models. Because the former cannot identify the effects of budgetary institutions that do not vary in the cross-section, they regress the fixed effects on budgetary institutions. Their main finding is that states with the strictest budgetary institution - no-deficit carry forward - and the line item veto have lower deficits. They find that end of year balance requirements enforced as constitutional (not statutory) constraints by an elected, rather than politically appointed supreme court, affect states' general fund surpluses. However, beginning of year requirements or end-of-year requirements enforced by a politically appointed supreme court have no impact on general fund deficit behavior. They also find that states requiring referenda ahead of debt issues also have lower deficits. However, in contrast to other studies, they do not find an effect of divided government.

A number of studies have looked at the impact of restrictions on debt finance. Beverly Bunch (1991) considers the relationship between such limits and the number of state authorities and their scope. Although she finds some relationship between the two, the cross-sectional approach does not make such findings reliable, and the theoretical link is far from clear. Jurgen von Hagen (1991) considers the cross-sectional impact of debt limitations on state debt in 1985, and finds little effect. Kiewert and Szakaly (1996) look at the effect of state debt limitations on debt in US states using data from 19601990. They use a random effects model and find that states that prohibit guaranteed debt and require a referendum for approval had less guaranteed debt than those that required a supermajority or those with revenue-based limitations.

There is a large literature that looks at the effect of budgetary institutions on municipal bond markets, in particular bond ratings. This is not surprising in light of the above results - Poterba (1994b) shows that there is a close link between tax policy and bond yields. One of the earliest quantitative studies, Morris Goldstein and Geoffrey Woglom (1992), relates the interest rate on general obligation debt to the strictness of anti-deficit provisions as measured by the Advisory Council on Inter-governmental Relations for the period 1982-90. They find that restrictive fiscal limits are associated with lower interest rates. 
Poterba and Rueben (1999) examine the link between fiscal institutions and spreads on bond yields, using the Chubb yield spreads data, which are available as a panel for 40 states from 1973-1995. They show that states with binding tax limitations have a 15 to 20 basis points higher yield on their state bonds. This makes sense, if it makes it more costly for such states to raise revenues to repay their debts. Expenditure limitations have the opposite effect. Lowry and Alt (2001) describe a mechanism via which limits on carrying forward deficits improve the ability of investors to extract information from noisy signals. They find support for their views using panel data on yield spreads using data from 1973-1995. Poterba and Rueben (2001) use data from the National Association of State Budget Officers between 1988 and 1997 to investigate whether states with restrictive fiscal institutions use deficits less as a smoothing device against shocks to the fiscal system. Unexpected deficits are shown to have a particularly large effect in raising the bond yields of states with tax limits.

Douglas Holtz-Eakin (1988) considers the impact of the line-item veto on budgetary outcomes, using a variety of measures of state expenditures and tax revenues as the dependent variables from 1965-83, and a range of economic and political variables as controls. As well as looking at cross-sectional differences, Holtz-Eakin identifies the effect in a fixed effects model by interacting whether a state permits a line-item veto with the nature of political control, in particular with whether there is divided control of the legislature. The cross-sectional results find no effect of the line-item veto, consonant with Abrams and Dougan (1986). However, the fixed effects results suggest that when government power is divided between two parties - one controlling the executive and the other the legislature - then having the line-item veto reduces spending and raises taxes, leading to smaller deficits. The line-item veto appears to have most impact when there is a preference conflict. In contrast to Holtz-Eakin's cross-sectional results, Bohn and Inman (1996) find that mean state deficits are lower in states where the governor has a line-item veto.

Alt, Dreyer Lassen and Skilling (2001) correlate their budgetary transparency index, discussed above, with the size of government. The exercise is motivated by the theoretical approach of Ferejohn (1999) who argues that greater transparency will likely lead to voters being happier with larger levels of government spending. In a cross section using data from 1986-95, they find in favor of this hypothesis, with greater transparency being positively correlated with higher state spending per capita. They also find that trans- 
parency is positively correlated with the popularity of the governor. This work is important in bringing more specific aspects of the agency view to the data. Given current discussions about the importance of transparency in government, this is likely to be an important area in the future.

Crain and Timothy Murris (1995) consider how the fragmentation of the budgetary process affects taxing and spending in the states. The fact that the institutions are fixed in the cross-section does not permit a panel data analysis. They develop a cross-sectional analysis based on the period 198288 , and find that states with a centralized spending committee spend 8 percent less on average than those without. Revenues are higher by 28 percent on average in states with a combined revenue and spending committee.

We present results on the association between tax and expenditure limitations and state taxes and spending in Table 7.4. Controlling for state and year effects, and time-varying state-level variables, we find that non-binding limits (those that are advisory or require only a simple legislative majority to change) are not significantly correlated with either taxes per capita or spending per capita. However, potentially binding tax or expenditure limits are positively (i.e., perversely) correlated with taxes. This again highlights the problems associated with quantifying the impact of institutions on policy outcomes when the institutions may change in response to policy choices such as taxes and spending that citizens consider inappropriately high. We return to the issues associated with endogenous institutions in Section 8.

Estimates of the impact of supermajority rules and the line-item veto are also presented in Table 7.4. Like much of the literature, we find a large, negative and significant effect of supermajority rules on total taxes collected per capita. On average, and with all else held equal, state taxes per capita are roughly $\$ 46$ lower in the years after the state passes a supermajority requirement. This amounts to roughly 8 percent of state taxes during the period over which the estimation is run (1960-97). The supermajority requirement has a similarly large, negative effect on state spending (columns 6) but its effect is not significant when other rules are included in the regression (column 8).

In this period, only two states changed their rules on allowing the governor a line item veto: Iowa and Washington both moved to allow line item vetoes in 1969. Thus, the indicator that the governor is allowed a line item veto is identified only off of the difference in these two states before and after its passage (and is for that reason not particularly meaningful.) More interesting is the Holtz-Eakin interaction term of the line item veto with divided 
government. We find, in contrast to Holtz-Eakin, that in a divided government the line item veto reduces both taxes and spending. However, given that the coefficient on taxes is smaller in absolute terms than that on spending, the finding is still consistent with Holtz-Eakin's finding that deficits are lower in situations where there is divided government and a line item veto.

Overall, the evidence that we have presented, alongside that from the existing literature, supports an emerging consensus that government behavior can be influenced by budgetary rules. However, the exact form of the rules is important.

\subsection{Indirect Effects of Institutional Rules}

The theoretical discussion suggested a possible distinction between institutional rules that affect the policy process ex post and those that primarily have an effect on electoral outcomes. Institutions such as open primaries, voter registration laws and restrictions on corporate campaign contributions seem most likely to be examples of the institutions $I_{2 s t}$ which enter equation (3). These may in turn affect the equilibrium strategies chosen by parties. We would then expect the impact of these variables on policy to be mediated via their effect on election outcomes such as party competition or Democratic control of the legislature. We already know from section 5.5 that there are policy effects of these institutions. Table 7.5 explores whether their effect works via $\ell_{s t}$.

Column 1 of Table 7.5 shows that these institutions are highly significantly correlated with total taxes per capita. Specifically, open primaries and corporate restrictions are negatively and significantly correlated with taxes, while less-costly voter registration is positively and significantly correlated with taxes. The $F$-statistic of their joint significance is large $(F=20.22$, $p$-value $=0.0000)$. It is difficult to make a case that any of these institutional rules have a direct effect on taxes, which leads us to ask whether we might uncover the chain through which they do affect policy.

Column 2 of table 7.5 presents two-stage-least-squares (2SLS) estimates of the impact of party competition in the state legislature on total taxes, in which our measure of party competition is instrumented on the institutional rules. We find that, instrumented on open primaries, registration rules and corporate restrictions, party competition is negatively and significantly correlated with taxes. The results in column 2 suggest that a one standard deviation increase in competitiveness (an increase in our measure of 
0.07 points) is associated with a reduction in total taxes per capita of $\$ 240$, measured in $\$ 1982 .{ }^{51}$ This is roughly a one standard deviation decrease in taxes over this period (a one standard deviation decrease would amount to $\$ 230$ ). Moreover, we can compare the fit of two regressions - that in column 1, where the institutional rules are allowed to enter in an unrestricted fashion, and that in which the institutional rules enter only through their effect on predicted party competition. The $F$-test at the bottom of column 2 answers the question of whether the fit of the regression is significantly worse if we force the institutional rules to enter only through their effect on party competition. It is not: $F=0.76, p$-value $=.5483$, and we cannot reject that these rules are affecting total taxes solely through their effect on party competition. (Note that this does not prove that party competition is the mechanism at work - but it cannot be rejected by the data.) This suggests that these variables can be interpreted as being part of the vector $I_{2 s t}$ in equation (3).

We repeat this exercise in column 3 , here asking whether the institutional rules might be working through Democratic control. The 2SLS estimate of Democratic control is positive and significant. However, unlike the results for party competition, the fit of the regression in which the institutional rules are entering through the indicator of Democratic control is significantly worse than that when the institutional variables are unrestricted $(F=13.57, p$-value $=0.0000)$. When both predicted values are entered in the same regression, as in column 4, it is clear that party competition is the favored mechanism through which these institutional rules are affecting total taxes.

We present this discussion solely as an illustration. However, we believe that more generally this sort of exercise may prove useful when analyzing whether and how the legislative political landscape is affecting policy choice. For many analyses, the institutional rules will provide a source of exogenous variation in political control that can be used to analyze how policies change in response to the character of the legislature. In all of these analyses, it will be important to ask how the institutional rules have been set - a topic we turn to in the next section. More significantly, this exercise shows that there is scope for imposing some greater theoretical structure on the problem to analyze the effects of institutions on outcomes and to test that structure empirically.

\footnotetext{
${ }^{51}$ That is, $-3434.63 \times 0.07=-240.42$.
} 


\section{Endogenous Institutions}

The common assumption in the vast majority of cross-state studies is that the institutions are exogenous. This is more or less plausible depending on the time frame and issue in question. Endogeneity is really only part of a broader set of concerns about the possibility that institutions are correlated with omitted right hand side variables, and one hope is that state fixed effects and time-varying state-level variables will capture state differences that determine both institutions and policy. To better understand whether and when it is appropriate to take institutions as exogenous, we provide in this section a look at some of the systematic determinants of institutional rules.

Even if institutions do not change over time, there is no guarantee that it is legitimate to treat them as exogenous. Moreover, as we observed in our study of citizens' initiatives, it may be difficult to control for sources of unobserved heterogeneity with state fixed effects when institutions are fixed over time. Thus, it remains difficult to distinguish between a genuine institutional effect and the possibility that tastes for citizens' initiatives and taxation are correlated. The main hope here is that some kind of comparative static with respect to some exogenously changing variable can be identified and tested. For example, Besley and Coate (2000a) used the comparative static with respect to fuel prices to gauge the influence of elected versus appointed regulators even where the latter institution did not change.

The charge of endogeneity is not by itself very meaningful. The key empirical issue is to identify possible sources of correlation between institutional variables and the error term in an equation which has either $x_{j s t}$ or $\ell_{j s t}$ on the right hand side. The most difficult cases are those where there are good reasons to believe that there are shocks to the policy in question that drive the demand for institutional reform - as when states that have a history of deficits implement some kind of balanced budget rule. In each instance, the possible fix (if one exists) must be thought out on a case-by-case basis. It is unlikely that there is any kind of panacea for these problems.

Progress is most likely to come through an underlying theoretical account of what motivates institutional change. The large literature on strategic use of long-run policies is relevant here. The early literature - Persson and Svensson (1989) and Tabellini and Alesina (1987) focused on the strategic use of debt to constrain the flexibility of future incumbents. A general account of this type of argument and its relationship to the notion of political failure 
is in Besley and Coate (1998). Institutional reform is certainly one way of trying to influence future political outcomes. Our results on redistricting in Table 5.4 provide a particular angle on this showing that the composition of the legislature at the time of redistricting had an impact on subsequent patterns of representation.

In some contexts, the theory may give rise to a natural instrument for the institution in question. One of the main cases where this is an issue is the case of tax and expenditure limitations that were adopted comparatively recently and may have been favored in states that have a history of high spending. Reuben (1997) and Knight (2000) both use citizens' initiatives as instruments for tax and expenditure limitations and super-majority requirements respectively. While ingenious, there are a couple of drawbacks. First, for the reasons that we discussed in our treatment of citizens' initiatives above, fixed effects cannot be included and this may be a rather important omission. Second, in instrumenting one institution using another, we must assume that the institution used as an instrument is not itself correlated with the unobservables in the policy equation.

As discussed above, Stratmann and Aparicio-Castillo (2001) also consider the possibility that campaign finance laws are endogenously chosen to advantage the incumbents. They use state education as an instrument, finding that states with more educated voters tend to have a lower restriction on individual campaign limits.

In one of the few studies to examine directly the endogeneity of institutions, Hanssen (2001) considers the strategic use of appointment rules for state court judges. He argues that incumbents without firm control on the reins of power are likely to prefer more independent judiciaries given that they might not be in office in the future and perceive the judiciary as a check on future incumbents' behavior. However, a party which is expected to remain in office will not benefit from such countervailing powers. Hanssen considers the 27 changes in judicial selection rules over the period from 1950 to 1990. Modeling the timing of the switches as a function of the prevailing political conditions, he finds that firmer single party control is found to be associated with less independently accountable judiciaries.

The extent to which institutions respond to the political composition of the legislature, and to state demographic change, is explored in Table 8.1. Specifically, we ask whether current institutional rules on primaries, on voter registration, and on corporate campaign restrictions, are significantly correlated with measures of past political legislative control and with past 
demographic and economic variables. In the first column for each institutional rule, we regress the institution on lagged values of the proportion of Democrats in the state lower house in years t- $4, \mathrm{t}-6, \mathrm{t}-8$ and $\mathrm{t}-10$; the proportion of Democrats in the state upper house in years t-4, t- 6 , t- 8 and $\mathrm{t}-10$; indicators that the Democrats controlled both houses in t-4, t- $6, \mathrm{t}-8$ and t-10; and our measure of party competition in the legislature in t-4, t- $6, \mathrm{t}-8$ and $\mathrm{t}$ 10. (Our results are robust to the inclusion/exclusion of lags at t-4 and t-12.) In all of these regressions, we control for the same time-varying state-level variables described above, along with state fixed effects and year effects. We find - both for open primaries and for constraints on corporate contributions - that past legislative variables are significant determinants of current state policy. In the second column for each rule, we regress the institution on lagged values of state population, state income per capita, the proportion of the population aged 65 and above, and the proportion aged 5 to 17 in years $\mathrm{t}-4$, t-6, t-8, and t-10. We find, for open primaries, motor-voter registration, and corporate campaign restrictions, that these past economic and demographic variables are significant determinants of current rules. Jointly, the past economic and legislative variables are significant for open primaries, for motor-voter registration and for corporate restrictions.

In studying the impact of a particular institutional rules on policy outcomes, then, we must ask whether the determinants of the institutional rule are thought to have independent effects on current policy. For example, past legislatures may affect both the institutional rule (as we find that they do for corporate contributions) and may also tie the hands of the current legislature (for example, by taking on debt). As always, this must be addressed on a case-by-case basis.

\section{Concluding Remarks}

US states are an important laboratory for empirical investigation of policy processes. Much encouragement can be taken from the variety and richness of the existing body of cross-state literature on the policy impact of political institutions. There can be little doubt that the structure of political representation, the terms on which elections are fought, and the rules governing the policy process, all influence policy outcomes. Moreover the directions in which these influences go are forming an increasingly robust body of knowledge as the literature in this area matures. Above all, this is encouraging 
for the future theoretical work on political economy. For, without access to data and testing, there is little to anchor theoretical progress.

Apart from the detailed insights available in individual studies, the following five general lessons emerge. First, processes for the selection of candidates and for gaining access to the vote are strongly correlated with patterns of political representation. This should undermine the cynical view that elections are a veil that affect very little. This message is further reinforced by the second robust observation - that party control and identity matter. Early attempts to quantify this achieved mixed results. However, the more recent literature and findings shown here leave little doubt on this score. Our third robust finding is that elections serve a key role in achieving accountability - office holders who do not face reelection behave differently from those that do. Fourth, we would highlight the finding that efforts to empower or disempower policy makers through restrictions on taxes and expenditures are strongly correlated with differences in fiscal behavior. This suggests that the original Public Choice agenda, which centered on the debate of how to redesign the fiscal constitution, is not without substance when experiments in this area are tried. Finally, the data suggest in a variety of contexts that the there are empirical differences between the determinants and consequences of elections for Governors and the legislature. There is scope for making these more precise and developing their theoretical implications in more detail.

While our focus here is exclusively on the United States, we recognize the link between the progress in empirical political economy being made on US data and that made elsewhere. Of particular importance is the recent cross-country work by Persson and Tabellini (1999, 2002) and Gian-Maria Milesi-Ferretti, Roberto Perotti, and Massimo Rostagno (2002). They have been building a data set that models the differences between political institutions across countries. They have focused particularly on different models of the separation of powers and the extent to which systems are closer to proportional representation. Also related to the work on budgetary institutions in state levele data is cross-country work such as that undertaken by Alesina, Ricardo Hausman, Rudolf Hommes and Ernesto Stein [1999] for Latin America. It is clear that in all such work similar issues to those discussed here, such as identifying chains of influence and possible sources of endogeneity (particularly sources of unobserved heterogeneity) are relevant. Overall, this strand of research is complementary in its ambition and scope to that discussed here. Moreover, there are sources of variation that can be studied transnationally, but not using US states - variations in the electoral 
system being a key example.

There is also parallel work at a subnational level in other federal systems that exhibit important institutional variations. A good example is the work on citizens' initiatives in Switzerland by Pommerehne (1990) and Lars Feld and Matsusaka (1999). Pande (2001) exploits differences in rules that mandate representation of disadvantaged minorities (scheduled castes and scheduled tribes) in India. She finds that the transfer programs favoring the disadvantaged groups expand (other things being equal) when representation increases. Subnational work of this type is an important part of the agenda to deepen our empirical understanding of the policy process.

Viewed as applied economics, the empirical study of policy processes presents challenges. Ideally, the empirical agenda gives direction to theoretical modeling. At a general level, the median voter model, the workhorse of so much political economy modeling for more than a generation, receives little empirical support. It is indirectly refuted by two of the key findings from the literature. First, that institutions appear to affect the link between citizens' preferences and policy. Second, the identity of representatives, such as their gender and party affiliation, matters. The Downsian model, taken literally, encourages us to believe that institutions and parties are irrelevant - all that politicians care about is seeking out the preferred outcome of the median voter. It has been known for some time that this is problematic theoretically. It also appears that it does a poor job at fitting the data.

But what kind of theory is likely to work? First, it is clear a key role of parties with policy preferences, mediating between policy and preferences, is a promising component. Attention needs also to be paid to frameworks in which multiple issues are determined - the data suggest that different policy issues respond to institutions in heterogeneous ways. The predictions of agency theoretic models in which voters learn about their incumbents over time also appear to have some empirical relevance in understanding the data.

Overall, it is doubtful that any grand unifying theory will emerge. It is more realistic to expect piecemeal theoretical analyses that yield tight empirical predictions for a concrete institutional variation. However, establishing empirical regularities for their own sake also has a role to play in stimulating further theoretical work. 


\section{References}

[1] Abrams, Burton A. and William R. Dougan, [1986], "The Effects of Constitutional Restraints on Government Spending", Public Choice, 49(2), 101-16.

[2] Adams, James D. and Lawrence Kenny, [1986], "Optimal Tenure of Elected Public Officials," Journal of Law and Economics, 29(2), 30328.

[3] Adams, James D. and Lawrence Kenny, [1989], "The Retention of State Governors," Public Choice, 62(1), 1-13.

[4] Alesina, Alberto, [1988], "Credibility and Policy Convergence in a Two-Party System with Rational Voters," American Economic Review, 78(4), 796-806.

[5] Alesina, Alberto and Howard Rosenthal, [1995], Partisan Politics, Divided Government and the Economy, New York: Cambridge University Press.

[6] Alesina, Alberto, Ricardo Hausman, Rudolf Hommes and Ernesto Stein, [1999], "Budget Institutions and Fiscal Performance in Latin America," Journal of Development Economics, 59(2), 253-274.

[7] Alesina, Alberto and Nouriel Roubini, [1992], "Political Cycles in OECD Economies," Review of Economic Studies, 59(4), 663-88.

[8] Alt, James E. and Robert C. Lowry, [1994], "Divided Government, Fiscal Institutions and Budget Deficits: Evidence from the States", American Political Science Review, 88(4), 811-28.

[9] Alt, James E. and Robert C. Lowry, [2000], "A Dynamic Model of State Budget Outcomes and Divided Partisan Government," The Journal of Politics, 62, 1035-1069.

[10] Alt, James E., David Dreyer Lassen, and David Skilling, [2001], "Fiscal Transparency, Gubernatorial Popularity, and the Scale of Government: Evidence from the States," unpublished typescript. 
[11] Anderson, John E. and Hendrik Van der Berg, [1998], "Fiscal Decentralization and Government Size: an International Test for Leviathan Accounting for Unmeasured Economic Activity", International Tax and Public Finance, 5(2), 171-86.

[12] Bails, Dale, and Margie A. Tieslau, [2000], "The Impact of Fiscal Constitutions on State and Local Expenditures," Cato Journal, 20(2), 255277.

[13] Barrilleaux, Charles, [2000], "Party Strength, Party Change and Policy-Making in American States," Party Politics, 6(1), 61-73.

[14] Barro, Robert, [1973], "The Control of Politicians: An Economic Model," Public Choice, 14, 19-42.

[15] Becker, Gary, [1985], "Public Policies, Pressure Groups and Dead Weight Costs," Journal of Public Economics, 28, 329-347.

[16] Benabou, Roland [2000], "Unequal Societies: Income Distribution and the Social Contract," American Economic Review, 90(1), 96-129.

[17] Berry, Francis Stokes and Berry, William D., [1992], "Tax Innovation in the States: Capitalizing on Political Opportunity," American Journal of Political Science, 36(3), 715-742.

[18] Berry, William D., [1979], "Utility Regulation in the States: The Policy Effects of Professionalism and Salience to the Consumer," American Journal of Political Science, 23(2), 263-277.

[19] Berry, William D., Evan J. Ringquist, Richard C. Fording and Russell Hanson, [1998], "Measuring Citizen and Government Ideology in the American States, 1960-93," American Journal of Political Science, 42(1), 327-348.

[20] Besley, Timothy J. and Anne C. Case, [1995a], "Incumbent Behavior: Vote Seeking, Tax Setting and Yardstick Competition", American Economic Review 85(1), 25-45.

[21] Besley, Timothy and Anne Case, [1995b], "Does Political Accountability Affect Economic Policy Choices? Evidence From Gubernatorial Term Limits, Quarterly Journal of Economics 110(3), 769-98. 
[22] Besley, Timothy and Anne Case, [2000], "Unnatural Experiments? Estimating the Incidence of Endogenous Policies" Economic Journal, 110(467), F672-F694.

[23] Besley, Timothy and Stephen Coate, [1997], "An Economic Model of Representative Democracy," Quarterly Journal of Economics, 112, 85114.

[24] Besley, Timothy and Stephen Coate, [1998], "Sources of Inefficiency in a Representative Democracy: A Dynamic Analysis," American Economic Review,

[25] Besley, Timothy and Stephen Coate, [2000a], "Elected versus Appointed Regulators: Theory and Evidence," NBER Working Paper, No. 7579 .

[26] Besley, Timothy and Stephen Coate, [2000b], "Issue Unbundling via Citizens' Initiatives," NBER Working Paper, No. 8036.

[27] Besley, Timothy and Stephen Coate, [2001], "On the Public Choice Critique of Welfare Economics," forthcoming in Public Choice.

[28] Black, Duncan, [1987], The theory of committees and elections Norwell, Mass., Dordrecht and Lancaster: Kluwer Academic.

[29] Bohn, Henning and Robert Inman, [1996], "Balanced Budget Rules and Public Deficits: Evidence from the U.S.", National Bureau of Economic Investigation Working Paper, 5533.

[30] Bowler, Shaun, Todd Donavan and Caroline J. Tolbert, (eds) [1998], Citizens as Legislators: Direct Democracy in the United States, Columbus: Ohio State University Press.

[31] Brennan, Geoffrey and James M. Buchanan, [1980], The Power to Tax: Analytical Foundations of the Fiscal Constitution, Cambridge: Cambridge University Press.

[32] Brennan, Geoffrey and Alan Hamlin, [1998], "Constitutional Economics," in The New Palgrave Dictionary of Economics and the Law, edited by Peter Newman, London: MacMillan. 
[33] Broder, David S. [2000], Democracy Derailed: Initiative Campaigns and the Power of Money, New York, Harcourt Inc.

[34] Brown, Robert D. [1995], "Party Cleavages and Welfare Effort in the American States," American Political Science Review, 89(1), 23-33.

[35] Buchanan, James M., [1967], Public Finance in Democratic Process, Chapel Hill: University of North Carolina Press.

[36] Buchanan, James M., [1987], "Constitutional Economics," in New Palgrave Dictionary of Economics, (London: Macmillan and Co).

[37] Bunch, Beverly S., [1991], "The Effect of Constitutional Debt Limits on State Governments' Use of Public Authorities," Public Choice, 68(1-3), 57-69.

[38] Butler, David and Austin Ranney, [1978], Referendums : a comparative study of practice and theory, American Enterprise Institute, Washington DC.

[39] Carmines, Edward G., [1994], "Political Issues, Party Alignments, Spatial Models and the Post-New Deal Party System," in Dodd and Jillson (eds), New Perspectives on American Politics, Washington D.C., CQ Press.

[40] Case, Anne [1998], "The Effects of Stronger Child Support Enforcement of Non-marital Fertility," in Irwin Garfinkel, Sara McLanahan, Daniel Meyer and Judith Seltzer (eds.) Fathers Under Fire: The Revolution in Child Support Enforcement, Russell Sage Foundation, 191-215.

[41] Case, Anne, James R. Hines and Harvey S. Rosen, [1993], "Budget Spillovers and Fiscal Policy Interdependence: Evidence from the States," Journal of Public Economics, 52(3), 285-307.

[42] The Center for the American Woman and Politics, [1991] The Impact of Women in Public Office, Findings at a Glance, Rutgers University, New Brunswick N.J.

[43] Chubb, John, [1988], "Institutions, The Economy, and the Dynamics of States Elections," American Political Science Review, 82(1), 133-154. 
[44] Clarke, Wes, [1998], "Divided Government and Budget Conflict in the U.S. States," Legislative Studies Quarterly, 23(1), 5-22.

[45] Coate, Stephen, [2001], "Political Competition with Campaign Contributions and Informative Advertizing" typescript.

[46] Corrado, Anthony, Thomas E. Mann, Daniel R. Ortiz, Trevor Potter and Frank J. Sorauf (editors), [1997], Campaign Finance Reform: A Sourcebook, The Brookings Institution.

[47] Camobreco, John F., [1998], "Preferences, Fiscal Policies and the Initiative Process," Journal of Politics, 60, 819-29.

[48] Costello, Kenneth W., [1984], Electing Regulators: The Case of Public Utility Commissioners, Yale Journal on Regulation, 2, 83-105.

[49] Crain, Mark and Nicole V. Crain, [1998], "Fiscal Consequences of Budget Baselines", Journal of Public Economics, 67(3), 421-36.

[50] Crain, W. Mark and Robert E. McCormick, [1984], "Regulators as an Interest Group," in James M. Buchanan and Robert D. Tollison (eds), The Theory of Public Choice II, Ann Arbor: University of Michigan Press.

[51] Crain, W. Mark and Timothy J. Muris, [1995], "Legislative Organization of Fiscal Policy", Journal of Law and Economics, 38(2), 311-33.

[52] Crain, W. Mark and Lisa K. Oakley, [1995], "The Politics of Infrastructure", Journal of Law and Economics, 38(1), 1-17.

[53] Crain, W. Mark and Robert D. Tollison, [1976], "Campaign Expenditures and Political Competition", Journal of Law and Economics, 19(1), 177-88.

[54] Crain, W. Mark and Robert D. Tollison, [1977], "Attenuated Property rights and the Market for Governors", Journal of Law and Economics, 20(1), 205-11.

[55] Crain, W. Mark and Robert D. Tollison, [1993], "Time Inconsistency and Fiscal Policy: Empirical Evidence of U.S. States, 1969-89", Journal of Public Economics, 51(2), 153-59. 
[56] Denzau, Arthur T., Robert J. Mackay and Carolyn Weaver, [1981], "On the Initiative-Referendum Option and the Control of Monopoly Government," in Helen F. Ladd and T. Nicolaus Tideman (eds.), Tax and Expenditure Limitations, Washington DC: The Urban Institute.

[57] Diermeier, Daniel and Antonio Merlo, [2000], "Government Turnover in Parliamentary Democracies," Journal of Economic Theory, 94(1), 46-79.

[58] Dixit, Avinash, [1996], The Making of Economic Policy, Cambridge: MIT Press.

[59] Dixit, Avinash, and John Londregan, [1998], "Ideology, Tactics, and Efficiency in Redistributive Politics," Quarterly Journal of Economics, 113(2), 497-529.

[60] Downs, Anthony, [1957], An Economic Theory of Democracy, New York: Harper Collins.

[61] Downes, Thomas A., Richard F. Dye and Therese M McGuire, [1998], "Do Limits Matter? Evidence on the Effects of Tax Limitations on Student Performance", Journal of Urban Economics, 43(3), 401-17.

[62] Dye, Thomas F., [1984], "Party and Policy in the States," Journal of Politics, 46, 1097-1116.

[63] Edlund, Leena and Rohini Pande, [2001], "Why have Women become Left-Wing? The Political Gender Gap and the Decline in Marriage," forthcoming in the Quarterly Journal of Economics.

[64] Erikson, Robert S., Gerald C. Wright and John P. McIver, [1989], "Political Parties, Public Opinion and State Policy in the United States," American Political Science Review, 83(3), 729-750.

[65] Farnham, Paul G., [1990], "The impact of citizen influence on local government expenditure," Public Choice, 64, 201-21.

[66] Feddersen, Timothy and Wolfgang Pesendorfer, [2000], "Abstention in Elections with Asymmetric Information and Diverse Preferences," typescript. 
[67] Feld, Lars P. and Matsusaka, John G. [1999]; The Political Economy of Tax Structure: Some Panel Evidence for Swiss Cantons, typescript.

[68] Ferejohn, John, [1986], "Incumbent Performance and Electoral Control," Public Choice, 50, 5-25.

[69] Ferejohn, John, [1999], "Accountability and Authority: Toward a Theory of Political Accountability", in Adam Przeworski, Susan Stokes and Bernard Manin, (eds) Democracy, Accountability and Representation, Cambridge University Press.

[70] Fields, Joseph A., Klein, Linda S., and James M. Sfiridis, [1997], "A Market Based Evaluation of the Election versus Appointment of Regulatory Commissioners," Public Choice 92, 337-351.

[71] Filer John, Lawrence Kenny and Rebecca Morton, [1993], "Redistribution, Income, and Voting," American Journal of Political Science, 37 (1993): 63-87.

[72] Filer John, Lawrence Kenny and Rebecca Morton, [1991], "Voting Laws, Educational Policies, and Minority Turnout," Journal of Law and Economics, 34 (1991): 371-393.

[73] Fiorina, Morris P., [1981], Retrospective Voting in American National Elections, New Haven CT: Yale University Press.

[74] Formby, John P., Mishra, Banamber and Paul D. Thistle, [1995], "Public Utility Regulation and Bond Ratings," Public Choice 84, 119-136.

[75] Garand, James C., [1988], "Explaining Government Growth in the U.S. States," American Political Science Review, 82(3), 837-849.

[76] Gelman, Andrew and Gary King, [1994], "Enhancing Democracy Through Legislative Redistricting," American Political Science Review, 88(3), 541-59.

[77] Gerber, Elisabeth, [1996], "Legislative Response to Threat of Popular Initiatives," American Journal of Political Science, 40(1), 99-128.

[78] Gerber, Elisabeth, [1999], The Populist Paradox: Interest Group Influence and the Promise of Direct Legislation, Princeton NJ: Princeton University Press. 
[79] Gerber Elisabeth and Rebecca Morton, [1998a], "Primary Election Systems and Representation," Journal of Law, Economics and Organization, 14, 304-324.

[80] Gerber Elisabeth and Rebecca Morton, [1998b], "Electoral Institutions and Party Competition: The Effect of Nomination Procedures on Electoral Coalition Formation," typescript.

[81] Gilligan Thomas W. and John G. Matsusaka, [1995], "Deviations from Constituent Interests: The Role of Legislative Structure and Political Parties," Economic Inquiry, 23, 383-401.

[82] Goldstein, Morris and Geoffrey Woglom, [1992], "Market-based Fiscal Discipline in Monetary Unions: Evidence from the U.S. Municipal Bond Market," in M.B. Canzoneri, V. Grilli and P.R. Masson (eds), Establishing A Central Bank: Issues from Europe and Lessons from the U.S., New York, NY: Cambridge University Press.

[83] Green, Donald and Ian Shapiro, [1994], Pathologies of rational choice theory : a critique of applications in political science, New Haven : Yale University Press.

[84] Grogan, Colleen M., "Political-Economic Factors Influencing State Medicaid Policy," Political Research Quarterly, 47(3), 589-623.

[85] Grossman, Gene and Elhanan Helpman, [1996], "Electoral Competition and Special Interest Politics," Review of Economic Studies, 63(2), 265286.

[86] Hanssen, F. Andrew, [1999], "The Effect of Judicial Institutions on Uncertainty and the Rate of Litigation: The Election versus Appointment of State Judges," Journal of Legal Studies, 28(1), 205-32.

[87] Hanssen, F. Andrew, [2000], "Independent Courts and Administrative Agencies: An Empirical Analysis of the States," Journal of Law, Economics and Organization, 16(2), 534-71.

[88] Hanssen, F. Andrew, [2001], "Is there a Politically Optimal level of Judicial Independence?", Stanford Law School, The John M. Olin Working Paper Series No. 218. 
[89] Harris, Malcolm C., and Peter Navarro, [1983], "Does Electing Public Utility Commissioners Bring Lower Electric Rates?" Public Utilities Fortnightly, 112 (sept.), 23-88.

[90] Highton, Benjamin, [1997], "Easy Registration and Voter Turnout," The Journal of Politics, 59(2), 565-75.

[91] Hill, Kim Quaile, Jan E. Leighley and Hinton-Anderson, Angela, [1995], "Lower-Class Mobilization and Policy Linkage in the U.S. States," American Journal of Political Science, 39, 75-86.

[92] Holbrook, Thomas M., and Emily van Dunk, [1993], "Electoral Competition in the American States," American Political Science Review, 87(4), 955-962.

[93] Holsey, Cheryl M. and Thomas E. Borcherding, [1997], "Why does government's share of national income grow? An assessment of the recent literature on the U.S. experience," in Dennis C. Mueller (ed), Perspectives on Public Choice, Cambridge: Cambridge University Press.

[94] Holtz-Eakin, Douglas, [1988], "The Line Item Veto and Public Sector Budgets: Evidence from the States", Journal of Public Economics, 36(3), 269-92.

[95] Huckshorn, Robert J., [1985], "Who Got It? Who Gave It? The Enforcement of Campaign Finance Laws in the States", The Journal of Politics, 47(3), 773-789.

[96] Husted, Thomas A. and Lawrence W. Kenny, [1997], "The Effect of the Expansion of the Voting Franchise on the Size of Government", Journal of Political Economy, 105(1), 54-82.

[97] Jones, Ruth S., [1981], "State Public Campaign Finance: Implications for Partisan Politics," American Journal of Political Science, 25(2), 342-361.

[98] Joskow, Paul and Nancy Rose, [1989], "The Effects of Economic Regulation," in Richard Schmalensee and Robert Willig (eds), Handbook of Industrial Organization, Amsterdam: North Holland. 
[99] Kendall, Maurice G. and Alan Stewart, [1950], "The Law of the Cubic Proportion in Election Results," British Journal of Sociology, 1, 183-96.

[100] Kenyon, D and K. Benker, [1984], "Fiscal Discipline: lessons from the state experience," National Tax Journal, 37, 433-46.

[101] Key, Valdimer O., [1950], Southern politics in state and nation, New York : A.A. Knopf.

[102] Kiewiet, D. Roderick and Kristin Szakaly, [1996], "Constitutional Limits on Borrowing: an Analysis of State Bond Indebtedness", Journal of Law, Economics and Organization, 12(1), 62-97.

[103] Knight, Brian, [2000], "Supermajority voting requirements for tax increases: evidence from the states," Journal of Public Economics, 76, 41-67.

[104] Krone, Susan L. and Richard F. Winters, [1993], "Taxes and Voting: Electoral Redistribution in the American States," The Journal of Politics, 55(1), 22-40.

[105] Lascher Edward, L. Jr, Michael G. Hagen and Steven A. Rochlin, [1996], "Gun Behind the Door? Ballot Initiatives, State Policies and Public Opinion," The Journal of Politics, 58(3), 760-95.

[106] Laffont, Jean-Jacques, [2000], Incentives and Political Economy, Oxford: Oxford University Press.

[107] Ladd, Helen F. and Nicolaus Tideman, (eds) [1981], Tax and Expenditure Limitations, Washington DC: The Urban Institute Press.

[108] Levitt, Steven D. [1994], "Using Repeat Challengers to Estimate the Effect of Campaign Spending on Election Outcomes in the U.S. House," Journal of Political Economy, 102(4), 777-798.

[109] Levitt, Steven D. [1995], "Policy Watch: Congressional Campaign Finance Reform," Journal of Economic Perspectives, 9(1), 183-93.

[110] List, John and Daniel Sturm, [2001], "Politics and Environmental Policy: Theory and Evidence from U.S. States," unpublished typescript: University of Maryland and University of Munich. 
[111] Lott, John R., [2000], "A Simple Explanation for Why Campaign Expenditures are Increasing: The Government is Getting Bigger," Journal of Law and Economics, 43(2), 359-393.

[112] Lott, John R., Jr. and Stephen G. Bronars, [1993], "Time Series Evidence on Shirking in the U.S. House of Representatives," Public Choice, $76,125-49$.

[113] Lott, John R., Jr. and Kenny, Lawrence W. [1999], "Did Women's Suffrage Change the Size and Scope of Government?," Journal of Political Economy, 107(6), 1163-98.

[114] Lowry, Robert C., James E. Alt and Karen E. Ferree, [1998], "Fiscal Policy Outcomes and Electoral Accountability in American States," American Political Science Review, 92(4), 759-774.

[115] Lowry, Robert C. and James E. Alt, "A Visible Hand? Bond Markets, Political Parties, Balanced Budget Laws, and State Government Debt," Economics and Politics, 13(1), 49-72.

[116] Lijphart, Arend, [1999], Patterns of Democracy: Government Forms and Performance in Thirty-six Countries, New Haven, CT: Yale University Press.

[117] Lindbeck, Assar and Jorgen Weibull, [1993], "A Model of Political Equilibrium in a Representative Democracy," Journal of Public Economics, 51(2), 195-209.

[118] Magleby, David B. [1984], Direct Legislation: Voting on Ballot Propositions in the United States, Baltimore: The Johns Hopkins University Press.

[119] Maskin, Eric and Jean Tirole, [2001], "The Politician and the Judge", unpublished typescript.

[120] Matsusaka, John G., [1992], "Economics of Direct Legislation", Quarterly Journal of Economics, 107(2), 541-71.

[121] Matsusaka, John G., [1995], "Fiscal Effects of Voter Initiative: Evidence from the Last 30 Years", Journal of Political Economy, 103(3), 587-623. 
[122] Matsusaka, John G., [2000], "Problems with a Methodology Used to Evaluate the Voter Initiative," unpublished typescript.

[123] Matsusaka, John G. and Nolan M. McCarty, [1999], "Political Resource Allocation: Benefits and Costs of Voter Initiatives," typescript, Columbia University.

[124] McArthur, John and Stephen V. Marks, [1988], "Constituent Interest vs. Legislator Ideology: The Role of Political Opportunity Cost", Economic Inquiry 26(3), 461-70.

[125] Moomau, Pamela and Rebecca Morton, [1992], "Revealed Preferences for Property Taxes: An Empirical Study of Perceived Tax Incidence," Review of Economics and Statistics, 74 (1992): 176-179.

[126] Montenegro, Alvaro A., [1995], "Constitutional Design and Economic Performance", Constitutional Political Economy, 6, 161-169.

[127] Morton, Rebecca and Charles Cameron, [1992], "Elections and the Theory of Campaign Contributions: a Survey and Critical Analysis," Economics and Politics, 4, 79-108.

[128] Nannestad, Peter and Martin Paldam, [1994], "The VP-Function: A Survey of the Literature on Vote and Popularity Functions after 25 Years," Public Choice, 79(3-4), June 1994, 213-45.

[129] Navarro, Peter, [1982], "Public Utility Commission Regulation: Performance, Determinants and Energy Policy Impacts," The Energy Journal, 3(2), 119-139.

[130] Niemi, Richard G., Harold W. Stanley and Ronald J. Vogel, [1995], "State Economies and State Taxes: Do Voters Hold Governors Accountable?" American Journal of Political Science, 39(4), 936-57.

[131] North, Douglass, [1990], Institutions, Institutional Change and Economic Performance, Cambridge: Cambridge University Press.

[132] Osborne, Martin J. and Al Slivinski, [1996], "A Model of Political Competition with Citizen Candidates", Quarterly Journal of Economics, 111(1), 65-96. 
[133] Pande, Rohini, "Minority Representation and Policy Choices: The Significance of Legislator Identity," typescript.

[134] Peltzman, Sam, [1976], "Toward a More General Theory of Regulation," Journal of Law and Economics, 19(2), 211-40.

[135] Peltzman, Sam, [1987], "Economic Conditions and Gubernatorial Elections," American Economic Review, 77(2), 293-97.

[136] Peltzman, Sam, [1992], "Voters as Fiscal Conservatives," Quarterly Journal of Economics, 107(2), 327-61.

[137] Milesi-Ferretti, Gian Maria, Roberto Perrotti, and Massimo Rostagno [2002], "Electoral Systems and Public Spending," Quarterly Journal of Economics, 117(2), 609-658.

[138] Persson, Torsten and Lars Svensson, [1989], "Why a Stubborn Conservative Would Run A Deficit: Policy with Time-Inconsistent Preferences," Quarterly Journal of Economics, 104, 325-346.

[139] Persson, Torsten and Guido Tabellini, [1999], "The Size and Scope of Government: Comparative Politics with Rational Politicians", European Economic Review, 43, 699-735.

[140] Persson, Torsten and Guido Tabellini, [2000], Political Economics: Explaining Economic Policy, Cambridge, MIT Press.

[141] Persson, Torsten and Guido Tabellini, [2002], Economic Policy in Representative Democracies, forthcoming Cambridge, MIT Press.

[142] Plotnick, Robert D. and Richard F. Winters, [1985], "A PoliticoEconomic Theory of Income Redistribution," The American Political Science Review, 79, 458-73.

[143] Pommerehne, Werner W., [1990], "The Empirical Relevance of Comparative Institutional Analysis," European Economic Review, 34(2-3), 458-69.

[144] Poterba, James M., [1994a], "State Responses to Fiscal Crisis: the Effects of Budgetary Institutions and Politics", Journal of Political Economy, 102(4), 799-821. 
[145] Poterba, James M., [1994b], "Tax Policy Changes and the Pricing of Tax-Exempt Bonds," in Susan C. Heide, Robert A. Klein and Jess Lederman (eds), The Handbook of Municipal Bonds, Chicago, IL: Probus Publishing.

[146] Poterba, James M., [1997], "Do Budget Rules Work?", [1997], in Alan Auerbach (ed), Fiscal Policy Lessons from Economic Research, MIT Press, 53-86.

[147] Poterba, James M. and Kim Rueben, [1999], "State Institutions and the U.S. Municipal Bond Market," in James M. Poterba and Jurgen von Hagen (eds), Fiscal Institutions and Fiscal Performance, NBER and University of Chicago Press.

[148] Poterba, James M. and Kim Rueben, [2001], "Fiscal News, State Budget Rules and, and Tax-Exempt Bond Yields," Journal of Urban Economics, forthcoming.

[149] Primeaux, Walter and Patrick Mann, [1986], "Regulator Selection Methods and Electricity Prices," Land Economics, 63(1), 1-13.

[150] Radcliff, Benjamin and Martin Saiz, [1995], "Race, Turnout, and Public Policy in the American States," Political Research Quarterly, 48(3), 775-794.

[151] Reed, W. Robert et al., [1998], "The Relationship Between Congressional Spending and Tenure with an Application to Term Limits", Public Choice, 94(1-2), 85-104.

[152] Roemer, John, [2001], Political competition: Theory and applications, Cambridge and London: Harvard University Press.

[153] Rogers, Diane Lim, and John H. Rogers, [2000], "Political competition and state government size: Do tighter elections produce looser budgets?" Public Choice, 105 (1), 1-21.

[154] Rogoff, Kenneth, [1990], "Equilibrium Political Budget Cycles," American Economic Review, 80(1), 21-36.

[155] Romer, Thomas and Howard Rosenthal, [1978], "Political Resource Allocation, Controlled Agendas, and the Status Quo," Public Choice, $33(4), 27-43$. 
[156] Rueben, Kim [1997], "Tax Limitations and Government Growth: The Effect of State Tax and Expenditure Limits on State and Local Government," typescript.

[157] Sass, Tim R. and Bobby J. Pittman Jr., [2000], "The changing impact of electoral structure on black representation in the South, 1970-96," Public Choice, 104, 369-388.

[158] Shadbegian, Ronald J., [1996], "Do Tax Expenditure Limitations Affect the Size and Growth of State Government?", Contemporary Economic Policy, 14(1), 22-35.

[159] Shepsle, Ken and Barry Weingast, [1981], "Structure Induced Equilibrium and Legislative Choice," Public Choice, 37(3), 503-19.

[160] Stigler, George and C. Friedland, [1962], "What the Regulators Regulate? The Case of Electricity," Journal of Law and Economics, 5, $1-16$.

[161] Stratmann, Thomas and Francisco J. Aparicio-Castillo [2001], "Competition Policy for Elections: Do Campaign Contribution Limits Matter?" unpublished typescript.

[162] Smart, Susan R., "The Consequences of Appointment Methods and Party Control for Telecommunications Pricing," [1994], Journal of Economics $\& 3$ Management Strategy, 3(2), 301-323.

[163] Strumpf, Koleman, [2000], "Does Decentralization Increase Policy Innovation?" typescript

[164] Tabellini, Guido and Alberto Alesina, [1990], "Voting on the Budget Deficit," American Economic Review, 80, 37-49.

[165] von Hagen, Jurgen, [1991], "A Note on the Empirical Effectiveness of Formal Fiscal Restraints", Journal of Public Economics, 44(2), 199210.

[166] Thomas, Sue, How Women Legislate, New York: Oxford University Press, 1994.

[167] Walker, Jack L., [1969], "The Diffusion of Innovation among the American States," American Political Science Review, 63, 880-99. 
[168] Winters, Richard F., [1976], "Party Control and Policy Change," American Journal of Political Science, 20(4), 597-636.

[169] Wolfers, Justin, [2001], "Are voters rational? Evidence from Gubernatorial Elections" typescript Stanford Business School.

[170] Wolfinger, Raymond E. and Steven J. Rosenstone, [1980], Who Votes?, New Haven: Yale University Press.

[171] Wright, Gerald C., Robert S. Erikson and John P. McIver, [1987], "Public Opinion and Policy Liberalism in the American States," American Journal of Political Science, 31(4), 980-1001.

[172] Zax, Jeffrey S., [1989], "Initiatives and Government Expenditures," Public Choice, 63, 267-77. 


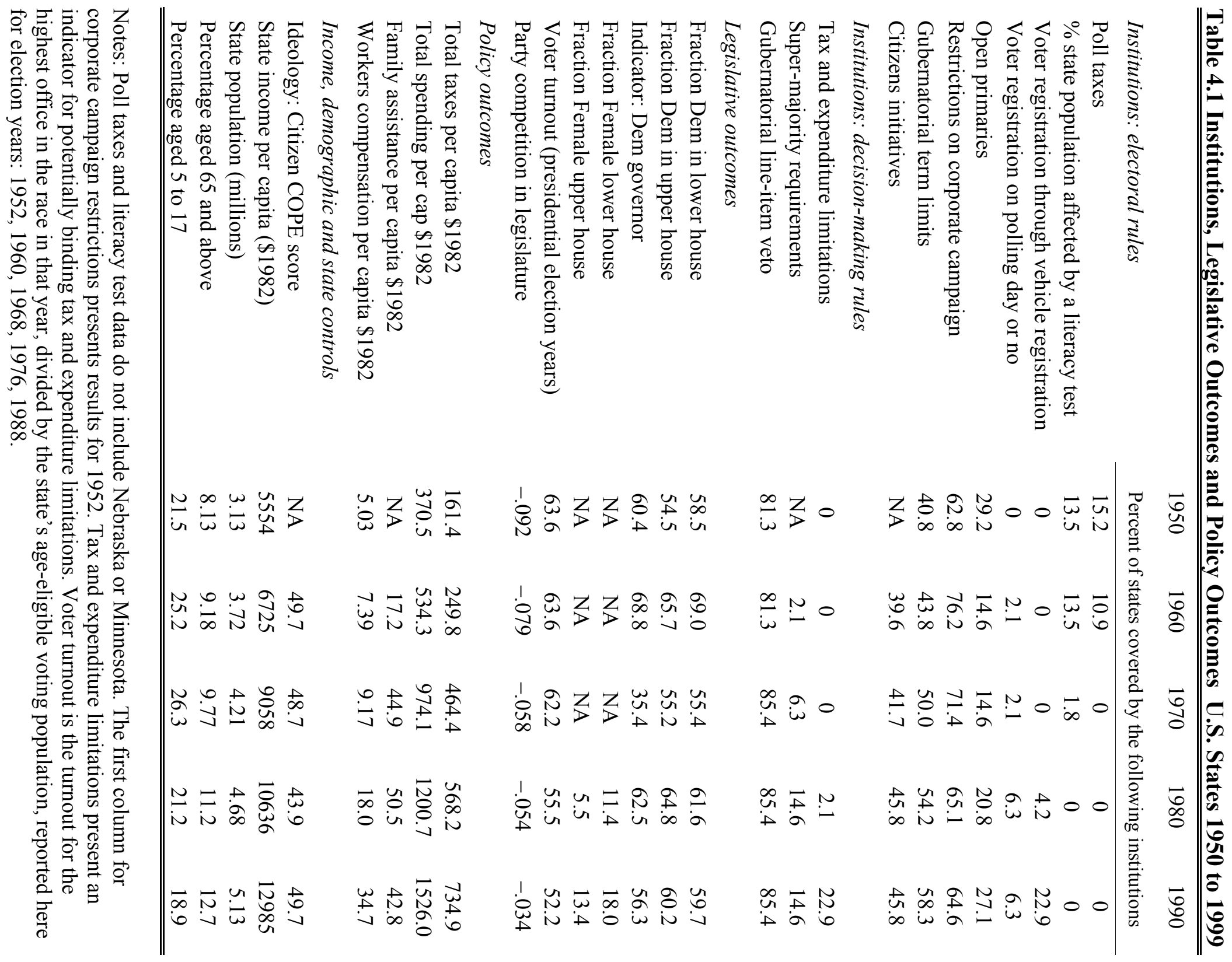




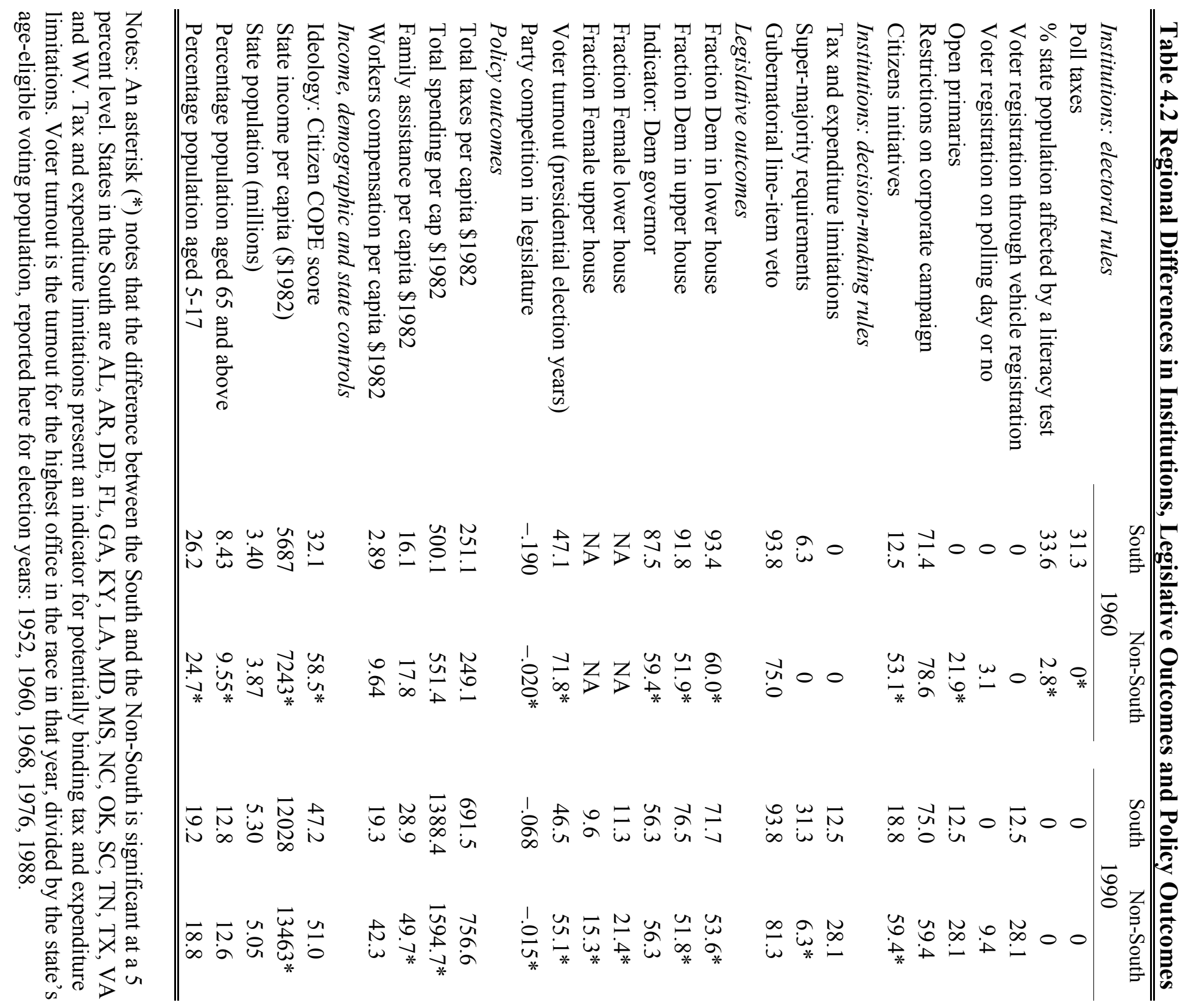


Table 5.1 Dependent Variable: Election Turnout of Age-eligible Voters

\begin{tabular}{|c|c|c|c|c|c|}
\hline & (1) & (2) & (3) & (4) & $(5)$ \\
\hline Poll tax & $\begin{array}{l}-.140 \\
(.010)\end{array}$ & & & & $\begin{array}{l}-.157 \\
(.013)\end{array}$ \\
\hline Literacy test & $\begin{array}{l}-.117 \\
(.011)\end{array}$ & -- & -- & -- & $\begin{array}{l}-.138 \\
(.012)\end{array}$ \\
\hline Citizen initiatives & -- & $\begin{array}{l}.033 \\
(.014)\end{array}$ & -- & -- & -- \\
\hline $\begin{array}{l}\text { Indicator: voter registration through } \\
\text { vehicle agency }\end{array}$ & -- & -- & $\begin{array}{l}.003 \\
(.008)\end{array}$ & -- & $\begin{array}{l}.004 \\
(.007)\end{array}$ \\
\hline $\begin{array}{l}\text { Indicator: voter registration possible on } \\
\text { polling day or no registration necessary }\end{array}$ & -- & -- & $\begin{array}{l}.017 \\
(.013)\end{array}$ & -- & $\begin{array}{l}.025 \\
(.014)\end{array}$ \\
\hline $\begin{array}{l}\text { Indicator: restriction on corporate } \\
\text { campaign contributions }\end{array}$ & -- & -- & - & $\begin{array}{c}.021 \\
(.006)\end{array}$ & $\begin{array}{l}.018 \\
(.005)\end{array}$ \\
\hline State fixed effects included? & Yes & No & Yes & Yes & Yes \\
\hline Years over which regression run & $\begin{array}{l}\text { even years } \\
1950-1998\end{array}$ & $\begin{array}{l}\text { even years } \\
1960-1998\end{array}$ & $\begin{array}{l}\text { even years } \\
1950-1998\end{array}$ & $\begin{array}{l}\text { even years } \\
1952-1998\end{array}$ & $\begin{array}{l}\text { even years } \\
1952-1998\end{array}$ \\
\hline Number of observations & 1174 & 958 & 1198 & 1060 & 1038 \\
\hline
\end{tabular}

Notes: Standard errors in parentheses. All regressions control for year effects, and include controls for the proportion of population aged 65 and above; the proportion of population aged 5 to 17; state income per capita in $\$ 1982$ and income per capita squared; state population and population squared. Omitted voter registration category in columns 3 and 5 is "conventional" registration. We do not include state fixed effects in column 2 because only 4 states changed whether they allowed initiatives over the period 1960 to 1998. In column 2, we estimate robust standard errors, and allow for correlation in the unobservables from the same state. Campaign finance data are currently not available for 1950. 
Table 5.2 Political institutions and representation

\begin{tabular}{|c|c|c|c|c|c|c|c|c|c|}
\hline \multirow[b]{2}{*}{ Poll tax } & \multicolumn{3}{|c|}{$\begin{array}{l}\text { Fraction Democrat in State } \\
\text { Upper House }\end{array}$} & \multicolumn{3}{|c|}{$\begin{array}{c}\text { Party Competition in } \\
\text { Legislature }\end{array}$} & \multicolumn{3}{|c|}{$\begin{array}{c}\text { Indicator: Democratic } \\
\text { Governor }\end{array}$} \\
\hline & $\begin{array}{l}.032 \\
(.028)\end{array}$ & $\begin{array}{c}.031 \\
(.030)\end{array}$ & -- & $\begin{array}{l}-.025 \\
(.009)\end{array}$ & $\begin{array}{c}.004 \\
(.010)\end{array}$ & -- & $\begin{array}{l}.148 \\
(.130)\end{array}$ & $\begin{array}{c}.046 \\
(.138)\end{array}$ & -- \\
\hline Literacy test & $\begin{array}{c}.081 \\
(.025)\end{array}$ & $\begin{array}{l}.082 \\
(.027)\end{array}$ & -- & $\begin{array}{l}-.022 \\
(.008)\end{array}$ & $\begin{array}{c}.001 \\
(.009)\end{array}$ & -- & $\begin{array}{c}.006 \\
(.116)\end{array}$ & $\begin{array}{l}-.101 \\
(.124)\end{array}$ & -- \\
\hline $\begin{array}{l}\text { Indicator: voter registration through vehicle } \\
\text { agency }\end{array}$ & $\begin{array}{l}-.015 \\
(.015)\end{array}$ & $\begin{array}{l}-.015 \\
(.015)\end{array}$ & -- & $\begin{array}{l}-.002 \\
(.005)\end{array}$ & $\begin{array}{l}-.003 \\
(.005)\end{array}$ & -- & $\begin{array}{c}.048 \\
(.069)\end{array}$ & $\begin{array}{c}.052 \\
(.069)\end{array}$ & -- \\
\hline $\begin{array}{l}\text { Indicator: voter registration possible on } \\
\text { polling day or no registration necessary }\end{array}$ & $\begin{array}{c}.056 \\
(.029)\end{array}$ & $\begin{array}{l}.056 \\
(.029)\end{array}$ & -- & $\begin{array}{l}-.039 \\
(.010)\end{array}$ & $\begin{array}{l}-.043 \\
(.010)\end{array}$ & -- & $\begin{array}{c}.007 \\
(.136)\end{array}$ & $\begin{array}{l}.025 \\
(.136)\end{array}$ & -- \\
\hline $\begin{array}{l}\text { Indicator: restriction on corporate campaign } \\
\text { contributions }\end{array}$ & $\begin{array}{l}.021 \\
(.011)\end{array}$ & $\begin{array}{l}.020 \\
(.011)\end{array}$ & -- & $\begin{array}{c}.010 \\
(.004)\end{array}$ & $\begin{array}{c}.007 \\
(.004)\end{array}$ & -- & $\begin{array}{c}.038 \\
(.049)\end{array}$ & $\begin{array}{c}.053 \\
(.049)\end{array}$ & -- \\
\hline $\begin{array}{l}\text { F-test: institutional variables } \\
\text { (p-value in parentheses) }\end{array}$ & $\begin{array}{c}4.47 \\
(.0005)\end{array}$ & $\begin{array}{c}4.10 \\
(.0011)\end{array}$ & -- & $\begin{array}{c}8.36 \\
(.0000)\end{array}$ & $\begin{array}{c}5.05 \\
(.0001)\end{array}$ & -- & $\begin{array}{c}0.48 \\
(.7913)\end{array}$ & $\begin{array}{c}0.50 \\
(.7772)\end{array}$ & -- \\
\hline Voter turnout & -- & $\begin{array}{l}-.002 \\
(.067)\end{array}$ & -- & -- & $\begin{array}{c}.178 \\
(.022)\end{array}$ & -- & -- & $\begin{array}{l}-.693 \\
(.312)\end{array}$ & -- \\
\hline IV estimation: Voter turnout & -- & -- & $\begin{array}{l}-.309 \\
(.116)\end{array}$ & -- & -- & $\begin{array}{c}.169 \\
(.038)\end{array}$ & - & -- & $\begin{array}{l}-.340 \\
(.531)\end{array}$ \\
\hline$F$-test: & -- & -- & $\begin{array}{c}3.79 \\
(.0021)\end{array}$ & -- & -- & $\begin{array}{c}5.88 \\
(.0000)\end{array}$ & -- & -- & $\begin{array}{c}0.54 \\
(.7467)\end{array}$ \\
\hline Number of observations & 1028 & 1026 & 1025 & 1040 & 1038 & 1025 & 1027 & 1025 & 1038 \\
\hline
\end{tabular}

Notes: Standard errors in parentheses. All regressions run over odd-years from 1953 to 1999 . All regressions control for year and state fixed effects, and include controls for the proportion of population aged 65 and above; the proportion of population aged 5 to 17 ; state income per capita in $\$ 1982$ and income squared; and state population and population squared. Omitted voter registration category is "conventional" registration. All control variables are lagged one year, to reflect the conditions in place at the time of the election. Results in column 3 are for instrumental variables estimation, where voter turnout is instrumented on the institutional rules that appear in columns 1 and 2 . The F-test in column 3 compares the fit of the regression using the predicted value to that in column 1 , where the institutional rules are allowed to enter in an unrestricted fashion. Results in column 6 report an analogous comparison for party competition in the legislature. We reject that these institutional rules are affecting fraction Democrats and party competition solely through their effect on voter turnout. 
Table 5.3 The impact of primary rules on turnout, ideology and party competition

\begin{tabular}{|c|c|c|c|c|c|c|c|c|}
\hline & & & & Dependen & Variable & & & \\
\hline & $\mathrm{Tu}$ & out & $\begin{array}{r}\text { Fra } \\
\text { Democr } \\
\text { lowe }\end{array}$ & $\begin{array}{l}\text { tion } \\
\text { s in state } \\
\text { house }\end{array}$ & $\begin{array}{r}\text { Fractio } \\
\text { in sta } \\
\mathrm{h}\end{array}$ & $\begin{array}{l}\text { women } \\
\text { lower } \\
\text { ise }\end{array}$ & $\begin{array}{r}\mathrm{Ab} \\
\text { diff } \\
\text { (ci } \\
\text { gove } \\
\text { COP }\end{array}$ & $\begin{array}{l}\text { lute } \\
\text { ence } \\
\text { en- } \\
\text { ment } \\
\text { score) }\end{array}$ \\
\hline Indicator: open primaries & $\begin{array}{l}.011 \\
(.007)\end{array}$ & $\begin{array}{c}.015 \\
(.007)\end{array}$ & $\begin{array}{c}.001 \\
(.012)\end{array}$ & $\begin{array}{l}-.001 \\
(.013)\end{array}$ & $\begin{array}{l}-.015 \\
(.007)\end{array}$ & $\begin{array}{l}-.014 \\
(.007)\end{array}$ & $\begin{array}{l}-3.47 \\
(2.30)\end{array}$ & $\begin{array}{l}-3.41 \\
(2.44)\end{array}$ \\
\hline Poll tax & & $\begin{array}{l}-.155 \\
(.134)\end{array}$ & & $\begin{array}{l}.014 \\
(.025)\end{array}$ & & - & & -- \\
\hline Literacy test & & $\begin{array}{l}-.137 \\
(.012)\end{array}$ & -- & $\begin{array}{c}.045 \\
(.022)\end{array}$ & -- & -- & -- & -- \\
\hline $\begin{array}{l}\text { Indicator: voter registration through vehicle } \\
\text { agency }\end{array}$ & -- & $\begin{array}{c}.010 \\
(.009)\end{array}$ & -- & $\begin{array}{c}.021 \\
(.017)\end{array}$ & -- & $\begin{array}{c}.009 \\
(.007)\end{array}$ & -- & $\begin{array}{l}-2.42 \\
(2.25)\end{array}$ \\
\hline $\begin{array}{l}\text { Indicator: voter registration possible on } \\
\text { polling day or no registration necessary }\end{array}$ & -- & $\begin{array}{c}.020 \\
(.016)\end{array}$ & -- & $\begin{array}{l}.039 \\
(.029)\end{array}$ & -- & $\begin{array}{l}-.056 \\
(.017)\end{array}$ & -- & $\begin{array}{c}2.95 \\
(3.72)\end{array}$ \\
\hline $\begin{array}{l}\text { Indicator: restriction on corporate campaign } \\
\text { contributions }\end{array}$ & -- & $\begin{array}{c}.018 \\
(.005)\end{array}$ & -- & $\begin{array}{c}.020 \\
(.010)\end{array}$ & -- & $\begin{array}{c}.015 \\
(.006)\end{array}$ & -- & $\begin{array}{r}1.89 \\
(1.43) \\
\end{array}$ \\
\hline Years over which regression run & $\begin{array}{c}\text { ever } \\
1950 \\
199\end{array}$ & $\begin{array}{l}\text { years } \\
1990 \\
1998\end{array}$ & $\begin{array}{c}\text { odd } \\
1951 \\
199\end{array}$ & $\begin{array}{l}\text { ears } \\
1991, \\
1999\end{array}$ & $\begin{array}{c}\text { odd } \\
1975 \\
199\end{array}$ & $\begin{array}{l}\text { ears } \\
1991, \\
1999\end{array}$ & $\begin{array}{l}\text { ever } \\
196\end{array}$ & $\begin{array}{r}\text { rears } \\
1990\end{array}$ \\
\hline Number of observations & 1099 & 942 & 1067 & 934 & 525 & 498 & 768 & 709 \\
\hline
\end{tabular}

Notes: Standard errors in parentheses. All regressions control for year and state effects, and include controls for the proportion of population aged 65 and above; the proportion of population aged 5 to 17; state income per capita in \$1982 and income squared; and state population and population squared. Omitted voter registration category in columns 3 and 5 is "conventional" registration. No registration was necessary in North Dakota from 1951 to 1998, and we have added that state to "registration possible on polling day." For regressions in columns 3-6, all control variables have been lagged one period, to reflect the conditions in place at the time of the election. 
Table 5.4 Redistricting and legislative composition

Indicator: Post-redistricting and Dems held unified legislature and governor during redistricting (year $\mathrm{t}-2$ )

Indicator: Post-redistricting and Reps held unified legislature and governor seat during redistricting (year $\mathrm{t}-2$ )

$F$-test: joint significance of redistricting with power variables (p-value)

Indicator: Democrats held unified legislature and governor seat (year t-2)

Indicator: Republicans held unified legislature and governor seat (year $\mathrm{t}-2$ )

Indicator: post redistricting

Years over which regression run

Dependent Variable:

Number of observations

\begin{tabular}{|c|c|c|c|}
\hline $\begin{array}{l}\text { Change in } \\
\text { Fraction Dem } \\
\text { lower house }\end{array}$ & $\begin{array}{l}\text { Change in } \\
\text { Fraction Dem } \\
\text { upper house }\end{array}$ & $\begin{array}{c}\text { Change in } \\
\text { number of } \\
\text { Dems lower } \\
\text { house }\end{array}$ & $\begin{array}{c}\text { Change in } \\
\text { number of } \\
\text { Dems upper } \\
\text { house }\end{array}$ \\
\hline .036 & .008 & 3.81 & 0.24 \\
\hline$(.010)$ & $(.010)$ & (1.16) & $(0.40)$ \\
\hline-.018 & -.031 & -2.06 & -0.97 \\
\hline$(.013)$ & $(.013)$ & $(1.50)$ & $(0.52)$ \\
\hline 10.37 & 4.16 & 9.20 & 2.65 \\
\hline$(.0000)$ & $(.0157)$ & $(.0000)$ & $(.0712)$ \\
\hline-.047 & -.039 & -4.73 & -1.45 \\
\hline$(.006)$ & $(.006)$ & $(0.70)$ & $(0.24)$ \\
\hline .055 & .056 & 5.81 & 2.03 \\
\hline$(.007)$ & $(.007)$ & $(0.83)$ & $(0.29)$ \\
\hline-.015 & .033 & -0.39 & 0.94 \\
\hline$(.035)$ & $(.036)$ & $(4.04)$ & $(1.40)$ \\
\hline all years & all years & all years & all years \\
\hline $1952-1995$ & $1952-1995$ & $1952-1995$ & $1952-1995$ \\
\hline 2024 & 2024 & 2024 & 2024 \\
\hline
\end{tabular}

Notes: Standard errors in parentheses. All regressions control for year and state effects, and include controls for state income per capita in \$1982 and income squared; and state population and population squared. Nebraska is removed from the analysis, because it has a unicameral, non-partisan legislature. Observations for Minnesota are present only from 1973 on. 
Table 5.5 Reduced form impact of institutional rules on state taxes and spending per capita

\begin{tabular}{lccccc} 
& \multicolumn{2}{c}{ Dependent Variable: } \\
& Total taxes & $\begin{array}{c}\text { Total } \\
\text { government } \\
\text { per capita } \\
\text { spending per } \\
\text { capita }\end{array}$ & $\begin{array}{c}\text { Total } \\
\text { transfers } \\
\text { payments } \\
\text { per capita }\end{array}$ & $\begin{array}{c}\text { Total family } \\
\text { assistance per } \\
\text { capita }\end{array}$ & $\begin{array}{c}\text { Total } \\
\text { compensatio } \\
\text { n payments } \\
\text { per capita }\end{array}$ \\
\cline { 2 - 6 } Open primaries & -19.25 & -18.24 & 31.8 & 2.73 & -6.31 \\
& $(8.03)$ & $(13.7)$ & $(10.9)$ & $(1.37)$ & $(1.80)$ \\
Indicator: voter registration through vehicle & 35.76 & 9.78 & 52.8 & 9.41 & 6.98 \\
agency & $(7.10)$ & $(11.5)$ & $(10.1)$ & $(1.27)$ & $(1.66)$ \\
& 120.38 & 114.7 & 0.77 & 20.5 & 1.64 \\
Indicator: voter registration possible on & $(13.41)$ & $(22.2)$ & $(18.5)$ & $(2.34)$ & $(3.08)$ \\
polling day or no registration necessary & -16.00 & 8.35 & 34.1 & 5.73 & -0.62 \\
Indicator: restriction on corporate campaign & $(5.33)$ & $(8.54)$ & $(7.57)$ & $(0.95)$ & $(1.25)$ \\
contributions & 28.46 & 7.55 & 13.87 & 35.94 & 7.83 \\
$F$-test: joint significance institutional variables & $(.0000)$ & $(.0000)$ & $(.0000)$ & $(.0000)$ & $(.0000)$ \\
$(p$-value in parentheses) & All years & All years & All years & All years & All years \\
Years over which regression run & $1958,1960-97$ & $1958,1960-96$ & $1958,1960-98$ & $1958,1960-98$ & $1958,1960-98$ \\
Number of observations & 1822 & 1781 & 1877 & 1877 & 1877 \\
\hline \hline
\end{tabular}

Notes: Standard errors in parentheses. All dependent variables are in 1982 dollars. All regressions control for year and state effects, and include controls for the proportion of population aged 65 and above; the proportion of population aged 5 to 17; state income per capita in $\$ 1982$ and income squared; and state population and population squared. Omitted voter registration category is "conventional" registration. No registration was necessary in North Dakota from 1951 to 1998, and we have added that state to "registration possible on polling day." Rules governing registration and voting have been lagged one or two periods, to reflect the conditions in place at the time of the election. 
Table 6.1 Legislative composition and policy choice

\begin{tabular}{|c|c|c|c|c|}
\hline \multirow[b]{3}{*}{ Fraction Democrat in state lower house } & \multicolumn{4}{|c|}{ Dependent Variable: } \\
\hline & $\begin{array}{l}\text { Total taxes per } \\
\text { capita }\end{array}$ & $\begin{array}{l}\text { Total spending } \\
\text { per capita }\end{array}$ & $\begin{array}{c}\text { Family } \\
\text { assistance per } \\
\text { capita }\end{array}$ & $\begin{array}{c}\text { Workers } \\
\text { compensation } \\
\text { per capita }\end{array}$ \\
\hline & $\begin{array}{c}78.71 \\
(19.79)\end{array}$ & $\begin{array}{l}101.38 \\
(33.33)\end{array}$ & $\begin{array}{l}28.78 \\
(4.28)\end{array}$ & $\begin{array}{l}-2.09 \\
(4.56)\end{array}$ \\
\hline Fraction Democrat in state upper house & $\begin{array}{c}10.49 \\
(18.64)\end{array}$ & $\begin{array}{c}2.49 \\
(31.50)\end{array}$ & $\begin{array}{c}9.03 \\
(3.87)\end{array}$ & $\begin{array}{c}9.42 \\
(4.29)\end{array}$ \\
\hline$F$-test: Coefficient on & 4.15 & 3.06 & 8.30 & 2.23 \\
\hline fraction upper house=fraction lower house & $(.0417)$ & $(.0802)$ & $(.0040)$ & $(.1359)$ \\
\hline $\begin{array}{l}\text { Indicator: Democrats control both lower and } \\
\text { upper house }\end{array}$ & $\begin{array}{l}12.68 \\
(5.51)\end{array}$ & $\begin{array}{l}-1.99 \\
(9.36)\end{array}$ & $\begin{array}{c}3.88 \\
(1.10)\end{array}$ & $\begin{array}{l}-2.15 \\
(1.26)\end{array}$ \\
\hline Indicator: Dem governor & $\begin{array}{l}-5.79 \\
(3.20)\end{array}$ & $\begin{array}{c}4.56 \\
(5.39)\end{array}$ & $\begin{array}{l}-0.78 \\
(0.64)\end{array}$ & $\begin{array}{c}2.17 \\
(0.73)\end{array}$ \\
\hline Party competition in legislature & $\begin{array}{l}-101.13 \\
(41.37)\end{array}$ & $\begin{array}{c}29.72 \\
(70.10)\end{array}$ & $\begin{array}{c}4.40 \\
(9.74)\end{array}$ & $\begin{array}{l}-53.0 \\
(9.39)\end{array}$ \\
\hline $\begin{array}{l}\text { F-test: joint significance of party variables } \\
\text { (p-value) }\end{array}$ & $\begin{array}{c}11.92 \\
(.0000) \\
\text { all years }\end{array}$ & $\begin{array}{c}3.43 \\
(.0043) \\
\text { all years }\end{array}$ & $\begin{array}{c}31.19 \\
(.0000) \\
\text { all years }\end{array}$ & $\begin{array}{c}10.98 \\
(.0000) \\
\text { all years }\end{array}$ \\
\hline Years over which regression run & $\begin{array}{l}1950-58 \\
1960-97\end{array}$ & $\begin{array}{l}1950-58 \\
1960-96\end{array}$ & $\begin{array}{c}1958, \\
1960-1998\end{array}$ & $\begin{array}{l}1950-58 \\
1960-98\end{array}$ \\
\hline Number of observations & 2131 & 2091 & 1817 & 2185 \\
\hline
\end{tabular}

Notes: Standard errors in parentheses. All regressions control for year and state effects, and include controls for the proportion of population aged 65 and above; the proportion of population aged 5 to 17; state income per capita in $\$ 1982$ and income squared; and state population and population squared. Nebraska is removed from the analysis, because it has a unicameral, non-partisan legislature. Observations for Minnesota are present only from 1973 on. 
Table 6.2 Ideology and policy choice

\section{State citizens' COPE score}

Fraction Democrat in state lower house

Fraction Democrat in state upper house

$F$-test: Coefficient on

fraction upper house $=$ fraction lower house

Indicator: Democrats control both lower and upper house

Indicator: Dem governor

Party competition in legislature

F-test: all political variables included in Table 6.1

Years over which regression run

Number of observations

\begin{tabular}{|c|c|c|c|}
\hline \multicolumn{4}{|c|}{ Dependent Variable: } \\
\hline $\begin{array}{l}\text { Total taxes per } \\
\text { capita }\end{array}$ & $\begin{array}{l}\text { Total spending } \\
\text { per capita }\end{array}$ & $\begin{array}{c}\text { Family } \\
\text { assistance per } \\
\text { capita }\end{array}$ & $\begin{array}{c}\text { Workers } \\
\text { compensation per } \\
\text { capita }\end{array}$ \\
\hline .400 & .545 & .201 & -.119 \\
\hline$(.188)$ & $(.3310$ & $(.038)$ & $(.050)$ \\
\hline 53.15 & 87.95 & 26.8 & 9.17 \\
\hline (22.12) & (39.39) & $(4.56)$ & $(5.97)$ \\
\hline 49.02 & 47.05 & 12.6 & -1.46 \\
\hline$(19.90)$ & $(35.41)$ & $(4.10)$ & $(5.37)$ \\
\hline 0.01 & 0.43 & 3.82 & 1.25 \\
\hline$(.9064)$ & $(.5137)$ & $(.0508)$ & $(.2629)$ \\
\hline 1.08 & -11.74 & 3.00 & -1.88 \\
\hline$(5.69)$ & $(10.16)$ & $(1.18)$ & $(1.54)$ \\
\hline-1.01 & -2.35 & -.314 & 1.21 \\
\hline$(3.23)$ & $(5.74)$ & $(.664)$ & $(0.87)$ \\
\hline 71.28 & 149.05 & -5.78 & -76.8 \\
\hline$(54.75)$ & (96.78) & (11.2) & $(14.7)$ \\
\hline 5.53 & 2.33 & 27.01 & 8.62 \\
\hline$(.0000)$ & $(.04040$ & $(.0000)$ & $(.0000)$ \\
\hline all years & all years & all years & all years \\
\hline $1960-93$ & $1960-1993$ & $1960-1993$ & $1960-1993$ \\
\hline 1576 & 1583 & 1583 & 1583 \\
\hline
\end{tabular}

Notes: Standard errors in parentheses. The $F$-tests in row 2 are for the joint significance of fraction Democrat in lower house, fraction Democrat in upper house, an indicator that the Democrats control both houses, an indicator for Democratic governor, and our measure of party competition in the legislature. All

regressions control for year and state effects, and include controls for the proportion of population aged 65 and above; the proportion of population aged 5 to 17 ; state income per capita in \$1982 and income squared; and state population and population squared. Nebraska is removed from the analysis, because it has a unicameral, non-partisan legislature. Observations for Minnesota are present only from 1973 on. All dollar-denominated variables are in 1982 dollars. 
Table 6.3 Women's legislative representation and policy choice

\begin{tabular}{|c|c|c|c|c|c|c|}
\hline \multirow[b]{3}{*}{ Fraction female state lower house } & \multicolumn{6}{|c|}{ Dependent Variable: } \\
\hline & \multicolumn{2}{|c|}{$\begin{array}{l}\text { Family assistance per } \\
\text { capita }(\$ 1982)\end{array}$} & \multicolumn{2}{|c|}{$\begin{array}{l}\text { Child support: } \\
\text { immediate withholding } \\
\text { upon delinquency }\end{array}$} & \multicolumn{2}{|c|}{$\begin{array}{c}\text { Child support: } \\
\text { paternity establishment } \\
\text { to age } 18\end{array}$} \\
\hline & $\begin{array}{l}.025 \\
(.008)\end{array}$ & $\begin{array}{l}.038 \\
(.009)\end{array}$ & $\begin{array}{l}-.053 \\
(.237)\end{array}$ & $\begin{array}{l}-.321 \\
(.311)\end{array}$ & $\begin{array}{l}-.369 \\
(.236)\end{array}$ & $\begin{array}{l}-.555 \\
(.310)\end{array}$ \\
\hline Fraction female state upper house & $\begin{array}{l}-.006 \\
(.006)\end{array}$ & $\begin{array}{l}! .011 \\
(.008)\end{array}$ & $\begin{array}{l}.712 \\
(.188)\end{array}$ & $\begin{array}{l}1.06 \\
(0.26)\end{array}$ & $\begin{array}{l}.311 \\
(.187)\end{array}$ & $\begin{array}{l}.883 \\
(.255)\end{array}$ \\
\hline $\begin{array}{l}\text { F-test joint significance female representation } \\
\text { (p-value) }\end{array}$ & $\begin{array}{c}4.85 \\
(.0000)\end{array}$ & $\begin{array}{l}8.96 \\
(.0000)\end{array}$ & $\begin{array}{c}7.21 \\
(.0000)\end{array}$ & $\begin{array}{c}8.62 \\
(.0002)\end{array}$ & $\begin{array}{c}2.26 \\
(.1044)\end{array}$ & $\begin{array}{c}6.71 \\
(.0000)\end{array}$ \\
\hline State citizens' COPE score & -- & $\begin{array}{l}.000 \\
(.000)\end{array}$ & -- & $\begin{array}{l}! .000 \\
(.001)\end{array}$ & -- & $\begin{array}{l}.001 \\
(.001)\end{array}$ \\
\hline Years over which regression run & $\begin{array}{l}\text { all years } \\
1975-98\end{array}$ & $\begin{array}{l}\text { all years } \\
1975-93\end{array}$ & $\begin{array}{l}\text { all years } \\
1975-97\end{array}$ & $\begin{array}{l}\text { all years } \\
1975-93\end{array}$ & $\begin{array}{l}\text { all years } \\
1975-97\end{array}$ & $\begin{array}{l}\text { all years } \\
1975-93\end{array}$ \\
\hline Number obs & 1152 & 912 & 1104 & 912 & 1104 & 912 \\
\hline
\end{tabular}

Notes: Standard errors in parentheses. All regressions control for year and state effects, and include controls for the proportion of population aged 65 and above; the proportion of population aged 5 to 17; state income per capita in \$1982 and income squared; and state population and population squared. All dollardenominated variables are in 1982 dollars. 


\begin{tabular}{|c|c|c|c|c|}
\hline \multirow[b]{4}{*}{ Indicator: State Allows Citizens' Initiatives } & \multicolumn{4}{|c|}{ Dependent Variable: } \\
\hline & $\begin{array}{c}\text { Total taxes } \\
\text { per capita }\end{array}$ & $\begin{array}{c}\text { Total } \\
\text { income taxes } \\
\text { per capita }\end{array}$ & $\begin{array}{l}\text { Government } \\
\text { spending per } \\
\text { capita }\end{array}$ & $\begin{array}{c}\text { Family } \\
\text { Assistance } \\
\text { per capita }\end{array}$ \\
\hline & \multicolumn{4}{|c|}{ OLS with robust standard errors } \\
\hline & $\begin{array}{l}-30.78 \\
(30.22)\end{array}$ & $\begin{array}{l}-34.02 \\
(32.96)\end{array}$ & $\begin{array}{l}-35.00 \\
(51.34)\end{array}$ & $\begin{array}{l}-.995 \\
(4.69)\end{array}$ \\
\hline & \multicolumn{4}{|c|}{ Random effects models } \\
\hline Indicator: State Allows Citizens' Initiatives & $\begin{array}{l}-38.40 \\
(11.82)\end{array}$ & $\begin{array}{l}-51.98 \\
(9.62)\end{array}$ & $\begin{array}{c}20.57 \\
(19.25)\end{array}$ & $\begin{array}{l}-1.76 \\
(2.11)\end{array}$ \\
\hline Years over which regression run & $\begin{array}{l}\text { all years } \\
1960-97\end{array}$ & $\begin{array}{l}\text { all years } \\
1960-97\end{array}$ & $\begin{array}{l}\text { all years } \\
1960-96\end{array}$ & $\begin{array}{l}\text { all years } \\
1960-98\end{array}$ \\
\hline \multirow[t]{2}{*}{ Number obs } & 1817 & 1824 & 1776 & 1872 \\
\hline & \multicolumn{4}{|c|}{ Regression on state means } \\
\hline Indicator: State Allows Citizens' Initiatives & $\begin{array}{l}-28.50 \\
(36.11)\end{array}$ & $\begin{array}{c}-45.83 \\
(37.20)\end{array}$ & $\begin{array}{l}-74.42 \\
(58.83)\end{array}$ & $\begin{array}{l}-1.14 \\
(5.26)\end{array}$ \\
\hline Number of observations & 48 & 48 & 48 & 48 \\
\hline
\end{tabular}

Notes: Standard errors in parentheses. All regressions include year indicators and controls for the proportion of population aged 65 and above; the proportion of population aged 5 to 17; state income per capita in $\$ 1982$ and income squared; and state population and population squared. We do not include state fixed effects because only 4 states changed whether they allowed initiatives over the period 1960 to 1998. (These were: FL 1972, IL 1971, MS 1992, and WY 1968). For all regressions in panel one, we estimate robust standard errors, and allow for an unspecified pattern of correlation in the unobservables from the same state. Panel two allows for state random effects. Panel three estimates between state regressions on state means. 


\section{Table7.2 Political business cycles}

\begin{tabular}{|c|c|c|c|c|c|c|}
\hline \multirow[b]{3}{*}{ Indicator: gubernatorial election in $t+1$} & \multicolumn{6}{|c|}{ Dependent Variable: } \\
\hline & \multicolumn{3}{|c|}{ State income per capita } & \multicolumn{3}{|c|}{ State unemployment rate } \\
\hline & $\begin{array}{c}-36.80 \\
(197.53)\end{array}$ & $\begin{array}{c}-5.41 \\
(149.95)\end{array}$ & $\begin{array}{c}16.48 \\
(54.73)\end{array}$ & $\begin{array}{l}-.122 \\
(.145)\end{array}$ & $\begin{array}{c}.011 \\
(.154)\end{array}$ & $\begin{array}{c}.012 \\
(.113)\end{array}$ \\
\hline Indicator: gubernatorial election in $t+2$ & $\begin{array}{c}161.98 \\
(196.34)\end{array}$ & $\begin{array}{c}48.17 \\
(120.60)\end{array}$ & $\begin{array}{c}25.95 \\
(44.05)\end{array}$ & $\begin{array}{l}-.050 \\
(.145)\end{array}$ & $\begin{array}{l}-.088 \\
(.124)\end{array}$ & $\begin{array}{l}-.081 \\
(.090)\end{array}$ \\
\hline Indicator: gubernatorial election in $t+3$ & $\begin{array}{c}108.00 \\
(197.20)\end{array}$ & $\begin{array}{c}26.44 \\
(149.74)\end{array}$ & $\begin{array}{c}7.07 \\
(54.69)\end{array}$ & $\begin{array}{c}.136 \\
(.145)\end{array}$ & $\begin{array}{c}.061 \\
(.154)\end{array}$ & $\begin{array}{c}.048 \\
(.112)\end{array}$ \\
\hline $\begin{array}{l}\text { F-test: joint significance of election variables } \\
\text { (p-value) }\end{array}$ & $\begin{array}{l}0.44 \\
(.7246)\end{array}$ & $\begin{array}{l}0.08 \\
(.9710)\end{array}$ & $\begin{array}{l}0.13 \\
(.9417)\end{array}$ & $\begin{array}{l}1.15 \\
(.3270)\end{array}$ & $\begin{array}{l}0.35 \\
(.7865)\end{array}$ & $\begin{array}{c}0.51 \\
(.6756)\end{array}$ \\
\hline Year effects? & no & yes & yes & no & yes & yes \\
\hline State effects? & no & no & yes & no & no & yes \\
\hline Number obs & 1820 & 1820 & 1820 & 1606 & 1606 & 1606 \\
\hline
\end{tabular}

Notes: Standard errors in parentheses. 
Table 7.3 Binding Term Limits and Policy Choice

\begin{tabular}{|c|c|c|c|c|}
\hline \multirow[b]{3}{*}{$\begin{array}{l}\text { Indicator: Incumbent governor } \\
\text { cannot stand for reelection }\end{array}$} & \multicolumn{4}{|c|}{ Dependent Variable: } \\
\hline & \multicolumn{2}{|c|}{ Total taxes per capita } & \multicolumn{2}{|c|}{ Total spending per capita } \\
\hline & $\begin{array}{l}-6.40 \\
(4.28)\end{array}$ & $\begin{array}{l}1216.73 \\
(514.32)\end{array}$ & $\begin{array}{l}14.80 \\
(6.73)\end{array}$ & $\begin{array}{l}1968.81 \\
(820.91)\end{array}$ \\
\hline $\begin{array}{l}\text { Indicator: Incumbent cannot } \\
\text { stand for reelection } \times \text { year }\end{array}$ & -- & $\begin{array}{l}-0.619 \\
(0.260)\end{array}$ & -- & $\begin{array}{l}-0.990 \\
(0.416)\end{array}$ \\
\hline Years over which regression & all years & all years & all years & all years \\
\hline run & $1950-97$ & $1950-97$ & $1950-1996$ & $1950-1996$ \\
\hline Number obs & 2249 & 2249 & 2208 & 2208 \\
\hline
\end{tabular}

Notes: Standard errors in parentheses. All regressions control for year and state effects, and include controls for the proportion of population aged 65 and above; the proportion of population aged 5 to 17; state income per capita in $\$ 1982$, income squared and cubed; and state population, population squared and cubed. All dollar-denominated variables are in 1982 dollars. 
Table 7.4 Incumbent Discretion and Policy Choice

\begin{tabular}{|c|c|c|c|c|c|c|c|c|}
\hline \multirow[b]{3}{*}{$\begin{array}{l}\text { Indicator: Non-binding tax or expenditure } \\
\text { limitation }\end{array}$} & \multicolumn{8}{|c|}{ Dependent Variable: } \\
\hline & \multicolumn{4}{|c|}{ Total taxes per capita } & \multicolumn{4}{|c|}{ Total spending per capita } \\
\hline & $\begin{array}{c}4.79 \\
(7.61)\end{array}$ & -- & -- & $\begin{array}{r}-16.28 \\
(7.87)\end{array}$ & $\begin{array}{l}-10.07 \\
(12.17)\end{array}$ & -- & -- & $\begin{array}{l}-44.71 \\
(13.45)\end{array}$ \\
\hline $\begin{array}{l}\text { Indicator: Potentially binding tax or expenditure } \\
\text { limitation }\end{array}$ & $\begin{array}{l}24.13 \\
(9.09)\end{array}$ & -- & -- & $\begin{array}{l}38.84 \\
(9.41)\end{array}$ & $\begin{array}{l}10.37 \\
(14.58)\end{array}$ & -- & -- & $\begin{array}{c}41.45 \\
(16.07)\end{array}$ \\
\hline Supermajority needed to increase taxes & -- & $\begin{array}{c}-46.12 \\
(8.51)\end{array}$ & -- & $\begin{array}{l}-52.28 \\
(10.06)\end{array}$ & -- & $\begin{array}{l}-46.27 \\
(13.94)\end{array}$ & -- & $\begin{array}{l}-8.61 \\
(17.15)\end{array}$ \\
\hline Indicator: Governor has a line item veto & -- & -- & $\begin{array}{l}-25.99 \\
(13.82)\end{array}$ & $\begin{array}{l}-37.73 \\
(16.03)\end{array}$ & -- & -- & $\begin{array}{c}3.01 \\
(23.34)\end{array}$ & $\begin{array}{c}4.00 \\
(27.42)\end{array}$ \\
\hline $\begin{array}{l}\text { Indicator: Governor's party is not that of the } \\
\text { united majority party in the legislature }\end{array}$ & -- & -- & $\begin{array}{l}10.37 \\
(8.12)\end{array}$ & $\begin{array}{c}9.07 \\
(8.36)\end{array}$ & -- & -- & $\begin{array}{c}32.44 \\
(13.71)\end{array}$ & $\begin{array}{l}33.15 \\
(14.29)\end{array}$ \\
\hline Line item veto $\times$ divided government & -- & -- & $\begin{array}{r}-25.34 \\
(8.83)\end{array}$ & $\begin{array}{c}-21.33 \\
(9.14)\end{array}$ & -- & -- & $\begin{array}{l}-45.47 \\
(14.91)\end{array}$ & $\begin{array}{l}-44.14 \\
(15.63)\end{array}$ \\
\hline Years over which regression run & all years & all years & all years & all years & all years & all years & all years & all years \\
\hline Y ears over which regression run & $1960-97$ & $1960-97$ & $1950-91$ & $1960-91$ & $1960-96$ & $1960-96$ & $1950-91$ & $1960-91$ \\
\hline Number of observations & 1817 & 1817 & 1961 & 1529 & 1776 & 1776 & 1968 & 1536 \\
\hline
\end{tabular}

Notes: Standard errors in parentheses. All regressions control for year and state effects, and include controls for the proportion of population aged 65 and above; the proportion of population aged 5 to 17; state income per capita in $\$ 1982$ and income squared; and state population and population squared. All dollar-denominated variables are in 1982 dollars. "Non-binding" tax and expenditure limitations are those that are either advisory or require only a simple legislative majority to amend or overrule. 
Table 7.5 Institutional Rules and Legislative Control

\begin{tabular}{|c|c|c|c|c|}
\hline \multirow[b]{2}{*}{ Open primaries } & \multicolumn{4}{|c|}{ Dependent Variable: Total taxes per capita } \\
\hline & $\begin{array}{l}-19.37 \\
(7.04)\end{array}$ & -- & -- & -- \\
\hline $\begin{array}{l}\text { Indicator: voter registration through } \\
\text { vehicle agency }\end{array}$ & $\begin{array}{l}32.02 \\
(6.86)\end{array}$ & -- & -- & -- \\
\hline $\begin{array}{l}\text { Indicator: voter registration possible on } \\
\text { polling day or no registration necessary }\end{array}$ & $\begin{array}{l}100.68 \\
(15.92)\end{array}$ & -- & -- & -- \\
\hline $\begin{array}{l}\text { Indicator: restriction on corporate } \\
\text { campaign contributions }\end{array}$ & $\begin{array}{l}-18.10 \\
(4.95)\end{array}$ & -- & -- & -- \\
\hline $\begin{array}{l}F \text {-test: joint significance institutional } \\
\text { variables ( } p \text {-value in parentheses) }\end{array}$ & $\begin{array}{c}20.22 \\
(.0000)\end{array}$ & -- & -- & -- \\
\hline IV: Party competition in legislature & -- & $\begin{array}{c}-3434.63 \\
(776.53)\end{array}$ & -- & $\begin{array}{l}-3376.73 \\
(928.31)\end{array}$ \\
\hline $\begin{array}{l}\text { IV: Democrats control both lower and } \\
\text { upper house }\end{array}$ & -- & -- & $\begin{array}{l}165.27 \\
(39.08)\end{array}$ & $\begin{array}{c}8.44 \\
(76.38)\end{array}$ \\
\hline $\begin{array}{l}F \text {-test (see notes to table) } \\
\text { ( } p \text {-value in parentheses) }\end{array}$ & -- & $\begin{array}{c}0.764 \\
(.5483)\end{array}$ & $\begin{array}{l}13.57 \\
(.0000)\end{array}$ & $\begin{array}{c}0.753 \\
(.5561)\end{array}$ \\
\hline Years over which regression run & \multicolumn{4}{|c|}{ All years $1950-58,1960-96$} \\
\hline Number of observations & 1925 & 1925 & 1925 & 1925 \\
\hline
\end{tabular}

Notes: Standard errors in parentheses. All regressions control for year and state effects, and include controls for the proportion of population aged 65 and above; the proportion of population aged 5 to 17; state income per capita in $\$ 1982$ and income squared; state population and population squared. All dollar-denominated variables are in 1982 dollars. In an auxiliary regression, we regress total taxes on all other right side variables and the predicted value of party competition in the legislature, where we use open primaries, voter registration through vehicle agency, voter registration on polling day, and restrictions on corporate contributions as instruments. The F-test in column 2 compares the fit of the regression using the predicted value to that in column 1, where the institutional rules are allowed to enter in an unrestricted fashion. Results in column 3 report an analogous comparison when an indicator that Democrats control both houses is instrumented using the institutional rules. We cannot reject that these institutional rules are affecting total taxes solely through their effect on party competition in the legislature. 
Table 8.1 The long-run impact of legislative control on state institutions

\begin{tabular}{|c|c|c|c|c|c|c|c|c|c|c|c|c|}
\hline \multirow[b]{2}{*}{$\begin{array}{l}F \text {-test: lagged legislative } \\
\text { variables (p-value) }\end{array}$} & \multicolumn{3}{|c|}{ Indicator: Open Primaries } & \multicolumn{3}{|c|}{$\begin{array}{c}\text { Indicator: Voter } \\
\text { Registration through } \\
\text { Vehicle Registration }\end{array}$} & \multicolumn{3}{|c|}{$\begin{array}{c}\text { Indicator: Day-of- } \\
\text { Election Registration or } \\
\text { No Registration }\end{array}$} & \multicolumn{3}{|c|}{$\begin{array}{l}\text { Indicator: Restrictions on } \\
\text { Corporate Contributions }\end{array}$} \\
\hline & $\begin{array}{l}2.19 \\
(.0194)\end{array}$ & -- & -- & $\begin{array}{c}0.69 \\
(.7903)\end{array}$ & -- & -- & $\begin{array}{c}0.34 \\
(.9893)\end{array}$ & -- & -- & $\begin{array}{c}1.70 \\
(.0811)\end{array}$ & -- & -- \\
\hline $\begin{array}{l}\text { F-test: lagged demographic } \\
\text { variables ( } p \text {-value) }\end{array}$ & -- & $\begin{array}{l}5.55 \\
(.0000)\end{array}$ & -- & -- & $\begin{array}{c}2.77 \\
(.0034)\end{array}$ & -- & -- & $\begin{array}{c}0.48 \\
(.9447)\end{array}$ & -- & -- & $\begin{array}{c}1.81 \\
(.0593)\end{array}$ & -- \\
\hline $\begin{array}{l}\text { F-test: lags in both } \\
\text { legislative and demographic } \\
\text { variables }\end{array}$ & -- & -- & $\begin{array}{c}6.12 \\
(.0000)\end{array}$ & -- & -- & $\begin{array}{l}3.96 \\
(.0000)\end{array}$ & -- & -- & $\begin{array}{c}0.40 \\
(.9961)\end{array}$ & -- & -- & $\begin{array}{c}2.28 \\
(.0053)\end{array}$ \\
\hline Number of Observations & 829 & 861 & 829 & 926 & 960 & 926 & 926 & 960 & 926 & 861 & 894 & 861 \\
\hline Years & even y & $\begin{array}{l}\text { years } 1960 \\
1996,199 \\
\end{array}$ & $\begin{array}{l}-1990, \\
8\end{array}$ & even & years 19 & $60-98$ & even & years 19 & 60-98 & even $y$ & years 1960 & -1998 \\
\hline
\end{tabular}

Notes: All regressions control for year and state effects, and include controls for the proportion of population aged 65 and above; the proportion of population aged 5 to 17; state income per capita in $\$ 1982$ and income squared; state population and population squared. The $F$-test for lagged legislative variables is a test for the joint significance of the following variables: the proportion of the lower house held by Democrats in years $\mathrm{t}-4, \mathrm{t}-6, \mathrm{t}-8$, and $\mathrm{t}-10$; the proportion of the state upper house held by Democrats in years $\mathrm{t}-4, \mathrm{t}-6, \mathrm{t}-8$, and $\mathrm{t}-10$; indicators that the Democrats controlled both houses in $\mathrm{t}-4$, $\mathrm{t}-6$, $\mathrm{t}-8$, and $\mathrm{t}-10$; and our measure of party competition in the legislature in $\mathrm{t}-4, \mathrm{t}-6, \mathrm{t}-8$, and $\mathrm{t}-10$. The F-test for lagged demographic variables is a test for the joint significance of the following variables: state income in periods $\mathrm{t}-4, \mathrm{t}-6, \mathrm{t}-8$ and $\mathrm{t}-10$; state population in periods $\mathrm{t}-4, \mathrm{t}-6, \mathrm{t}-8$ and $\mathrm{t}-10$; proportion of population aged 65 and above in $\mathrm{t}-4$, $\mathrm{t}-6, \mathrm{t}-8$ and $\mathrm{t}-10$; and proportion aged 5 to 17 in $\mathrm{t}-4, \mathrm{t}-6, \mathrm{t}-8$, and $\mathrm{t}-10$. Results reported are were estimated using robust standard errors. 
Figure 1. Organization of the text

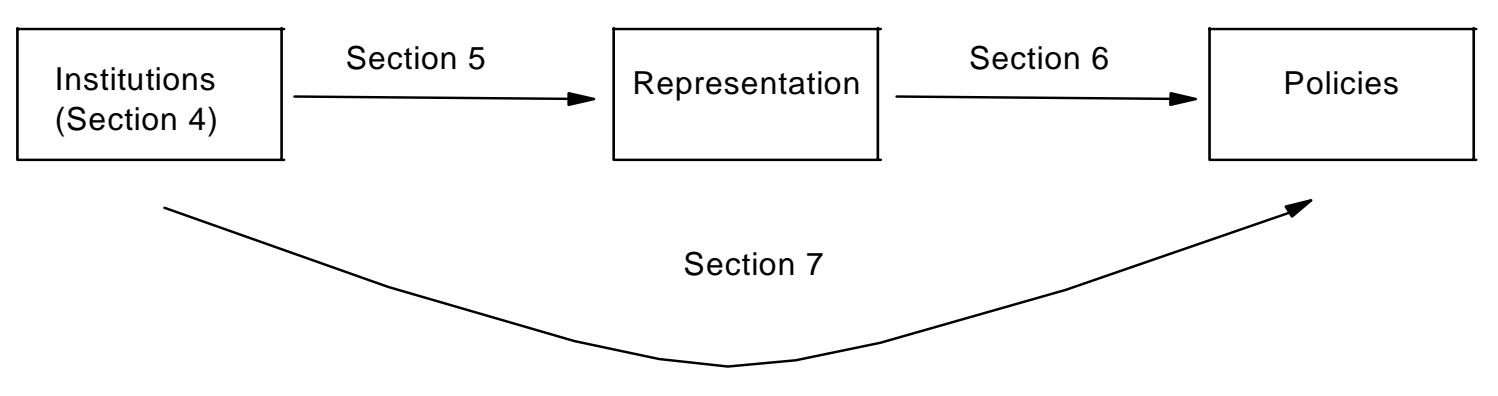


Figure 2. The abolition of literacy tests, and the composition of state upper houses

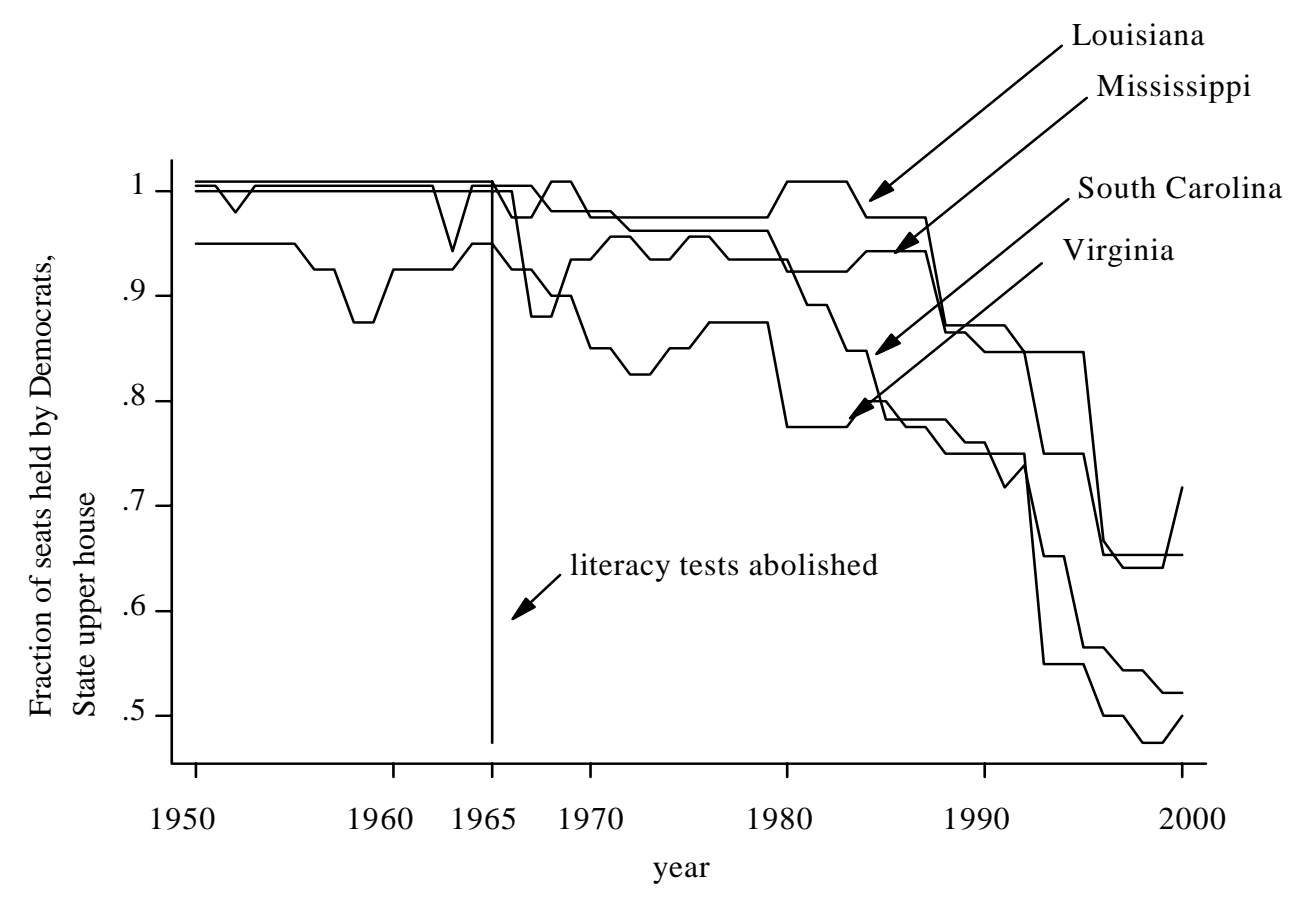


Figure 3. The changing impact of term limits on total taxes per capita

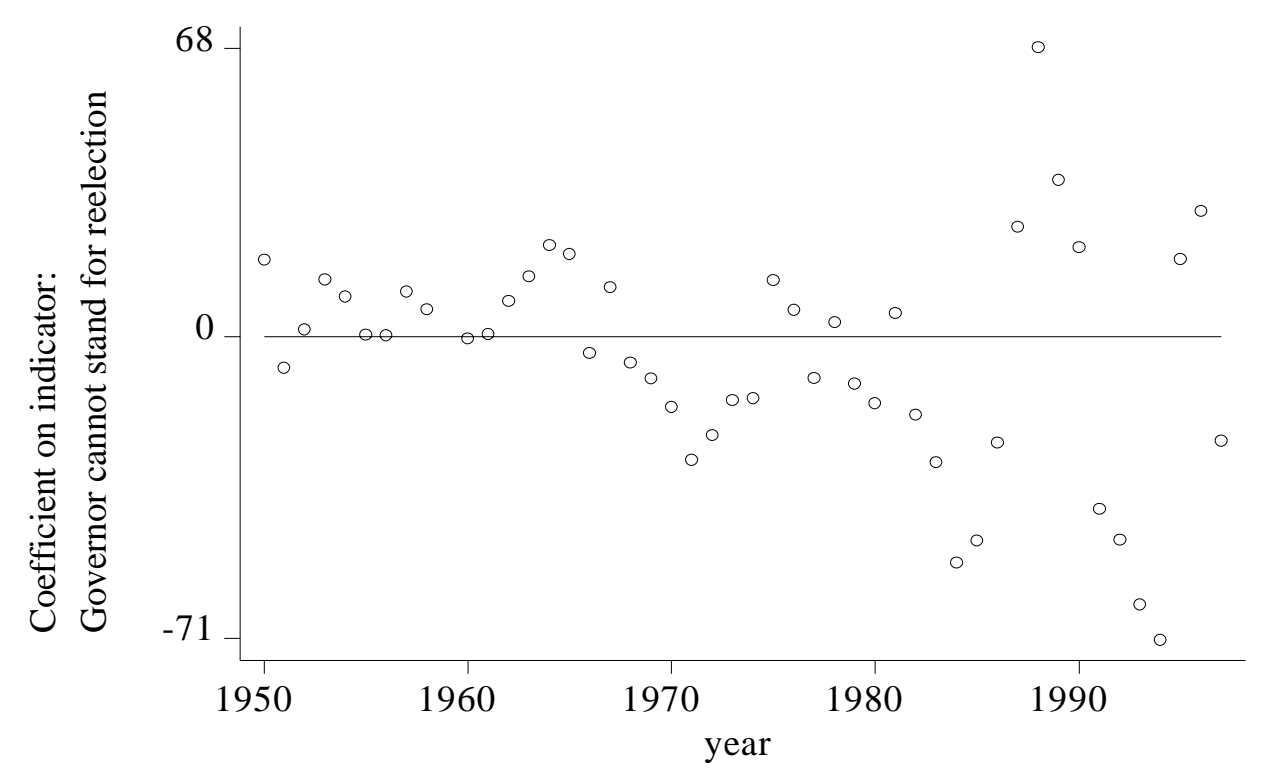

